\title{
Long-term integrated biogeochemical budget driven by circulation in the eastern subpolar North Atlantic
}

\author{
Fontela Marcos ${ }^{1,}{ }^{*}$, Mercier Herle ${ }^{2}$, Pérez Fiz F ${ }^{1}$ \\ ${ }^{1}$ Instituto de Investigaciones Marinas, IIM-CSIC, 36208 Vigo, Spain \\ ${ }^{2}$ CNRS, Laboratoire d'Océanographie Physique et Spatiale, UMR 6523 CNRS-IFREMER-IRD- \\ University of Brest, Plouzané, France \\ * Corresponding author : Marcos Fontela, email address : $\underline{\text { mfontela@iim.csic.es }}$
}

\begin{abstract}
:
The eastern subpolar North Atlantic (eSPNA) is a key region in the Atlantic Meridional Overturning Circulation (AMOC), playing an important role in biogeochemical cycles and climate regulation. Quantitative basin-scale biogeochemical budgets are still scarce despite the current need of establishing baselines of knowledge in a changing ocean. The physico-chemical data from the eight repetitions of the OVIDE section (2002-2016) are an unique opportunity to develop a novel evaluation of biogeochemical budgets in the eSPNA by combining robust and well established decadal mean mass transports with carbon variables, oxygen and inorganic nutrients in a full-depth inverse box model. The net balance between the carbon fixation and the respiration throughout the whole water column shows that the eSPNA is an important dissolved inorganic carbon (DIC) sink area where $119 \pm 43 \mathrm{kmol} \cdot \mathrm{s}-1$ and $49 \pm 31 \mathrm{kmol} \cdot \mathrm{s}-1$ of organic and inorganic carbon, respectively, are currently exported. The uptake due to mixed layer depth oxygenation of $807 \pm 114 \mathrm{kmol} \cdot \mathrm{s}-1$ of oxygen from the atmosphere and its subsequent southward export are responsible for deep Atlantic Ocean oxygenation. Deep water formation processes connect the northward upper limb with the southward lower limb of the AMOC leading to tracer export to the deep ocean. With regard to the net macronutrient budgets, all element consumptions are balanced within uncertainties. The results presented here for carbon export and oxygen uptake are in agreement with the upper range of previous observations based on different methods. The findings of this integrated budget driven by circulation in the highly dynamic region of the eSPNA can be taken as a reference in future biogeochemical evaluations of the North Atlantic.
\end{abstract}

Highlights

- A large DIC sink due the biological pump is quantified in the eSPNA. The eSPNA is an autotrophic area of DIC sink $\left(168 \pm 53 \mathrm{kmol} \cdot \mathrm{s}^{-1}\right)$ and oxygen uptake. Whole-water column biogeochemical budgets are based on 14 years of observations. Budgets of elements $\mathrm{C}, \mathrm{O}, \mathrm{N}, \mathrm{P}$ and $\mathrm{Si}$ are consistently integrated and optimized.

Keywords : Subpolar North Atlantic, biogeochemical cycles, carbon cycle, Nutrient cycles, oxygenation, Carbon sinks, Oceanic transports 


\section{Introduction}

Knowledge of the North Atlantic Ocean mean circulation has been greatly improved during the XXI century, with repeated ship-based measurements, moorings, drifters, profiling floats -Argoand satellite altimetry (Hansen and Østerhus, 2000; Kanzow et al., 2010; Willis, 2010; Sarafanov et al., 2012; McCarthy et al., 2015; Roessler et al., 2015; Daniault et al., 2016; Smeed et al., 2014; 2018). Budgets of mass, heat and salt have been constructed (Lumpkin and Speer, 2007; Lozier et al., 2008) and their analysis brought much insight on the North Atlantic circulation but studies of biogeochemical cycles at basin-scale are few or fragmented (Álvarez et al., 2002; Maze et al., 2012, Zunino et al., 2015).

Carbon (C) plays a central role in ocean biogeochemical cycles not only by its relevance in the climate system (in the form of carbon dioxide, $\mathrm{CO}_{2}$ ), but also because it is the central element of organic chemistry, therefore of life on Earth. The fixation of carbon into biogenic materials and its subsequent transfer to the deep ocean through sinking or subduction is the biological carbon pump (BCP) (Broecker and Peng, 1982). Along with the atmosphere-ocean exchanges of carbon due to physicochemical processes (solubility pump), this pump sets the ocean vertical carbon gradient (Volk and Hoffert, 1985). Marine primary producers convert dissolved inorganic carbon (DIC) into organic carbon (particulate -POC- and dissolved -DOC-). The vertical transport of POC out of the euphotic zone decreases with depth as organic matter is respired (remineralized) once again to DIC or transformed into DOC. Quantification of atmospheric $\mathrm{CO}_{2}$ sequestered by the BCP is key to evaluate the ocean carbon budget (Falkowski et al., 1998; Körtzinger et al., 2001; Sabine et al., 2004).

The drivers of the BCP are primary production and export. Marine net primary production (NPP), the photosynthetically fixed carbon, is $\sim 50 \mathrm{Pg}-\mathrm{C} \cdot \mathrm{yr}^{-1}$ at global scale (Longhurst et al., 1995; Behrenfeld and Falkowski, 1997; Falkowski et al., 1998), and $\sim 13 \mathrm{Pg}-\mathrm{C} \cdot \mathrm{yr}^{-1}$ for the Atlantic Ocean (Carr et al., 2006). Only a fraction of that organic carbon is exported out of the euphotic zone with current estimates ranging from $\sim 5$ to $16 \mathrm{Pg}-\mathrm{C} \cdot \mathrm{yr}^{-1}$ for the world ocean. There is, 


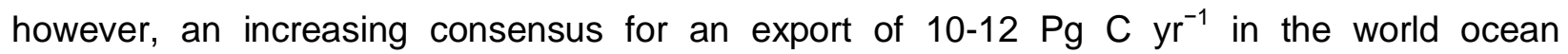
(Sambrotto et al., 1993; Falkowski et al., 1998; Laws et al., 2000; Henson et al., 2015) and an export close to $1.5 \mathrm{Pg}-\mathrm{C} \cdot \mathrm{yr}^{-1}$ in the North Atlantic ( Laws et al., 2000; Dunne et al., 2007; Sanders et al., 2014). Most of it is respired in the upper $2000 \mathrm{~m}$, as suggested by measurements that showed that vertical flux of organic carbon at that depth is only 0.3-0.7 Pg C $\mathrm{yr}^{-1}$ for the global ocean (del Giorgio and Duarte, 2002; Arístegui et al., 2003; Lutz et al., 2007; Honjo et al., 2008; Henson et al., 2012; Guidi et al., 2015). With an area of $41.5 \times 10^{6} \mathrm{~km}^{2}$ (Eakins and Sharman, 2010) and a mean vertical flux at $2000 \mathrm{~m}$ of $\sim 1.5-2 \mathrm{~g}-\mathrm{C} \cdot \mathrm{m}^{-2} \cdot \mathrm{yr}^{-1}$ (Honjo et al., 2008, Henson et al., 2012), the organic carbon export at $2000 \mathrm{~m}$ in the North Atlantic would be in the range 62-83 Tg-C.yr ${ }^{-1}$. Practically, less than $1 \%$ of the $\mathrm{CO}_{2}$ fixed by photosynthesis reaches $1000 \mathrm{~m}$ or deeper and constitutes a long-term sink for atmospheric $\mathrm{CO}_{2}$ (Martin et al., 1987; Ducklow et al., 2001; Primeau et al., 2005; Poulton et al., 2006; Lampitt et al., 2010; Legendre et al., 2015). Global synthesis of export fluxes points out that in the eSPNA the vertical export of organic particles collected at $2000 \mathrm{~m}$ depth with sediment traps is more than twice the global average and up to five times bigger than the export of inorganic carbon (Honjo et al., 2008).

Many questions on the carbon and related biogeochemical cycles remain unsolved in the eSPNA. How much carbon is exported to the deep (>2000 m) ocean? What is the contribution of organic carbon/ $\mathrm{CaCO}_{3}$ to this export? Can a long-term evaluation quantify properly the airsea $\mathrm{O}_{2}$ flux? The aim of this analysis based on data at the basin-scale is to gain some insight into these questions. This study provides balanced biogeochemical budgets of carbon variables, dissolved inorganic nutrients and oxygen using an over-determined system of mass balance equations consistent with stoichiometric relationships. Production and consumption of organic matter in the ocean plays a role not only in $\mathrm{C}$ cycling, but also in the cycles of nitrogen $(\mathrm{N})$, phosphorus (P), silicon (Si), and oxygen $\left(\mathrm{O}_{2}\right)$. Redfield (1934) and Redfield et al.(1963) proposed that on a global annual mean the organic matter is produced in constant molar element ratios. The element ratios are useful tools to evaluate the BCP because they allow the conversion of budgets based on nutrients or oxygen into carbon units applying a stoichiometric ratio (Körtzinger et al., 2001; Álvarez et al., 2002; Waniek et al., 2005; Hartman et al., 2010; Maze et al., 2012). With a full-depth budget constrained by physical circulation, we evaluated the net balance between the carbon fixation and the respiration throughout the whole water column. The objective is to derive consistent estimates for the exports of organic carbon $\left(\mathrm{E}_{\mathrm{C}_{\text {org }}}\right)$ 
and $\mathrm{CaCO}_{3}\left(\mathrm{E}_{\mathrm{CaCO}_{3}}\right)$ and evaluate the biogeochemical sinks of elements in the Subpolar North Atlantic.

The area of analysis in the Subpolar North Atlantic is located at the confluence of the northwardflowing upper limb and the southward-flowing lower limb of the Atlantic Meridional Overturning Circulation (AMOC) (Fig.1). Previous studies reported a southward export of DIC, nutrients and oxygen $\left(\mathrm{O}_{2}\right)$ toward the subtropical Atlantic (Álvarez et al., 2002, 2003) across section WOCE A25, a section comparable to OVIDE (García-lbáñez et al., 2015; Fig. 1). But more recently, using OVIDE data and an improved circulation model (Lherminier et al., 2007, 2010), the transport of DIC and nitrate $\left(\mathrm{NO}_{3}{ }^{-}\right)$was reported northwards, phosphate $\left(\mathrm{PO}_{4}{ }^{-}\right)$transport was found negligible and $\mathrm{O}_{2}$ consistently showed a significant southward export ( Maze et al., 2012; Zunino et al., 2015). Regular deep convection events in the Irminger and Labrador Seas (de Jong and de Steur, 2016; Fröb et al., 2016; Piron et al., 2017) make the eSPNA a hotspot for long-time sequestration of tracers in the deep ocean. Both from a nutrient $-\mathrm{O}_{2}$ budget (Maze et al., 2012, referred to hereafter as M12) and an inorganic carbon budget approach (Zunino et al., 2015, referred to hereafter as Z15), the zone has been identified as a C sink of $40 \mathrm{Tg}-\mathrm{C} \cdot \mathrm{yr}^{-1}$ $\left(\sim 100 \mathrm{kmol} \cdot \mathrm{s}^{-1}\right)$. A complete biogeochemical evaluation joining simultaneously carbon variables with oxygen and nutrients has never been proposed.

The text is organized as follows. The area of study, the model framework, the data set and associated uncertainties are described in Section 2. In Section 3, we present the results in terms of mass and biogeochemical budgets. Results are evaluated in Section 4 along with a discussion of the biogeochemical cycles. We list the conclusions of the article in Section 5.

\section{Material and methods}

\subsection{Region of study}

Biogeochemical budgets were derived for the region bounded at the south by the OVIDE section (from 40N Portugal to 60N Greenland, biennial periodicity since 2002, Table 1 ) and at the north by the Greenland-Scotland Ridge (G-SR, Fig. 1). In addition to the G-SR, the Reykjanes Ridge (RR), which is the segment of the Mid-Atlantic Ridge north of $50^{\circ} \mathrm{N}$, is a major topographic feature in the study area. The RR affects the circulation and separates the Irminger Basin (IB) from the Iceland and West European Basins. The region encompassing the Iceland and West European Basins will be referred to hereinafter as the Eastern North Atlantic, ENA (Fig. 1). We defined the eastern Subpolar North Atlantic (eSPNA, $3.78 \times 10^{12} \mathrm{~m}^{2}$ ) as the sum of IB $\left(6.12 \times 10^{11} \mathrm{~m}^{2}\right)$ and ENA $\left(3.18 \times 10^{12} \mathrm{~m}^{2}\right)$, separated by the RR. Similar box-model 
configurations were used previously (Lherminier et al., 2010; Maze et al., 2012; García-lbáñez et al., 2015).

The region of study contains several biogeographic regions or biomes ( Sarmiento et al., 2004; Fay and McKinley, 2014;). The main biome is the "Subpolar Seasonally Stratified", which represents $\sim 72 \%$ of the total area (Fig. 1). The intergyre region at the south belongs to the biome "Subtropical Seasonally Stratified" (Fig.1), which northern limit coincides with the position of the Subarctic Front (Daniault et al., 2016). The "North Atlantic Ice" biome is confined to the East Greenland shelves (Fig. 1).

\begin{tabular}{|c|c|c|c|c|c|}
\hline Date & Project & Expocode & $\begin{array}{c}\text { Research } \\
\text { Vessel }\end{array}$ & $\begin{array}{c}\text { Chief } \\
\text { scientist }\end{array}$ & $\begin{array}{r}\text { Velocity field } \\
\text { reference }\end{array}$ \\
\hline $\begin{array}{l}\text { Jun 10-Jul } 12 \\
2002\end{array}$ & OVIDE & 35TH20020610 & Thalassa & H. Mercier & $\begin{array}{r}\text { Lherminier et } \\
\text { al., } 2007\end{array}$ \\
\hline $\begin{array}{l}\text { Jun 4-Jul 7 } \\
2004\end{array}$ & OVIDE & 35TH20040604 & Thalassa & T. Huck & $\begin{array}{r}\text { Lherminier et } \\
\text { al., } 2007\end{array}$ \\
\hline $\begin{array}{l}\text { May 21-Jun } 28 \\
2006\end{array}$ & OVIDE & 06MM20060523 & M.S. Merian & P. Lherminier & $\begin{array}{r}\text { Lherminier et } \\
\text { al., } 2010\end{array}$ \\
\hline $\begin{array}{l}\text { Jun 10-Jul } 10 \\
2008\end{array}$ & OVIDE & 35TH20080610 & Thalassa & B. Ferron & $\begin{array}{l}\text { Gourcuff et } \\
\text { al., } 2011\end{array}$ \\
\hline $\begin{array}{l}\text { Jun 8-Jul } 7 \\
2010\end{array}$ & & 35TH20100610 & Thalassa & V. Thierry & $\begin{array}{r}\text { Mercier et al., } \\
2015\end{array}$ \\
\hline $\begin{array}{l}\text { Jun 23-Aug } 12 \\
2012 \\
\end{array}$ & CATARINA & 29AH20120622 & $\begin{array}{l}\text { Sarmiento } \\
\text { de Gamboa }\end{array}$ & A. F. Ríos & $\begin{array}{r}\text { Daniault et al., } \\
2016\end{array}$ \\
\hline $\begin{array}{l}\text { May 20-Jun } 26 \\
2014\end{array}$ & GEOVIDE & 35PK20140515 & $\begin{array}{l}\text { Pourquoi } \\
\text { Pas? }\end{array}$ & P. Lherminier & $\begin{array}{l}\text { Zunino et } \\
\text { al., } 2017\end{array}$ \\
\hline $\begin{array}{l}\text { Jun 17-Jul 31 } \\
2016\end{array}$ & BOCATS & 29AH20160617 & $\begin{array}{c}\text { Sarmiento } \\
\text { de Gamboa }\end{array}$ & F.F.Pérez & $\begin{array}{l}\text { Pérez et } \\
\text { al., } 2018\end{array}$ \\
\hline
\end{tabular}




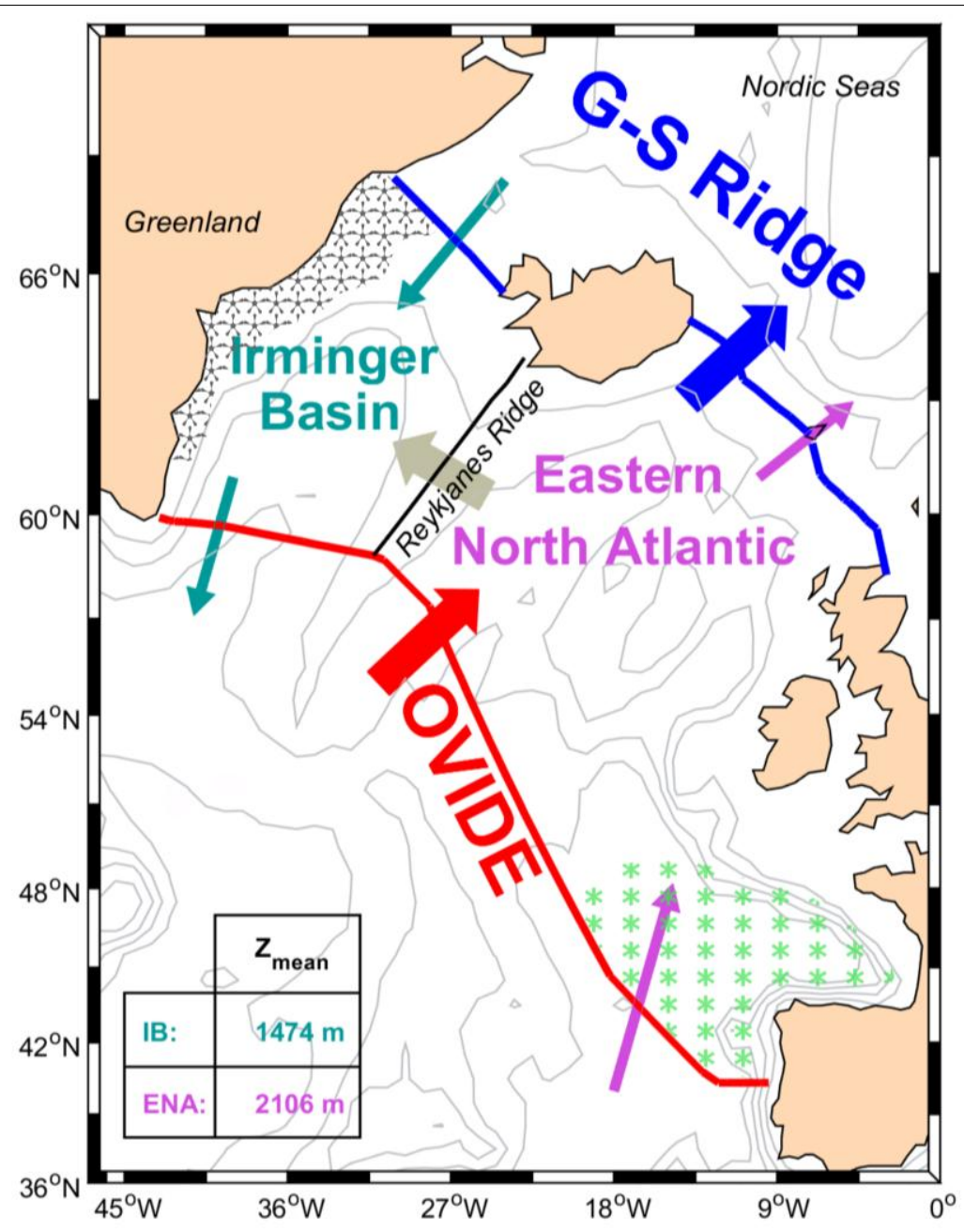

Figure 1. Map of the study region within the eastern subpolar North Atlantic. The OVIDE section (red thick line), the main axis of Reykjanes Ridge (black line) and Greenland- Scotland Ridge (GSR) (blue line) are indicated. They define the three boxes used in the model: Irminger Basin (IB), Eastern North Atlantic (ENA), and their sum, the eastern Subpolar North Atlantic (eSPNA). Arrows indicate net volume transports across OVIDE (red), G-I-S sills (blue), RR (grey), and the faces for the sub-boxes IB (cyan) and ENA (magenta). Arrow directions arbitrarily represent the subpolar gyre cyclonic circulation. The mean depth of each basin is reported in the lower left corner table. Following the biome characterization of Fay \& McKinley, (2014), the extension of the biomes "North Atlantic Ice" (grey hatched) and "North Atlantic Subtropical Seasonally Stratified" (green hatched) inside the eSPNA are represented. The remaining region belongs to the main biome of the eSPNA, the "North Atlantic Subpolar 
Seasonally Stratified".

\subsection{Inverse Model}

A budget of a biogeochemical tracer in any oceanic region is a balance between net gains and losses. The generic conservation equation (Eq. 1) accounts for lateral advection (mainly oceanic, but also freshwater supplies $\left.\left(F w_{\text {tracer }}\right)\right)$, air-sea gas exchange $\left(F_{\text {tracer }}^{\text {air-sea }}\right)$, additional inputs $(A D D$, like atmospheric deposition or biological fixation); and changes in the tracer inventory over time (i.e. net storage rates) $\left(S_{\text {tracer }}\right)$. These terms are balanced by a sink term due to biogeochemical activity $\left(B_{\text {tracer }}\right)$ :

$$
B_{\text {tracer }}=-\nabla \text { tracer } T+F w_{\text {tracer }}+F_{\text {tracer }}^{\text {air-sea }}+A D D-S_{\text {tracer }} \quad(\text { Equation } 1)
$$

The first term of the right-side of the equation is the tracer transport divergence $\left(\nabla_{\text {tracer }} T\right)$, the difference between oceanic tracer transports out of the box and tracer transports into the box. Fluxes into the box are positive while fluxes out of the box are negative. All terms represent contributions integrated from the surface of the ocean to the bottom. Eddy diffusive fluxes are neglected in Eq. 1.

We combined in a single model a set of interrelated biogeochemical conservation equations that were solved simultaneously and consistently. The model includes conservation equations for six tracers with key roles in biogeochemical cycles: DIC, alkalinity -the excess of proton acceptors over proton donors (Wolf-Gladrow et al., 2007), oxygen, nitrate, phosphate and silicate (Eq. 27). Only the significant inputs, i.e. the atmospheric nitrogen deposition (AND) and the nitrogen fixation (NF), are included in the nitrate equation (Eq. 4).

$$
\begin{aligned}
& B_{D I C}=-\nabla D I C \cdot T+F w_{D I C}+F^{C O 2 \text { air-sea }}-S_{\text {DIC }} \quad \text { (Equation 2) } \\
& B_{A l k}=-\nabla A l k \cdot T+F w_{A l k}-S_{A l k} \quad \text { (Equation 3) } \\
& B_{O 2}=-\nabla O_{2} \cdot T+F^{O 2 \text { air-sea }}-S_{O 2} \quad \text { (Equation 4) } \\
& B_{N O 3}=-\nabla N \cdot T+F w_{N O 3}+A N D+N F-S_{N O 3} \quad \text { (Equation 5) } \\
& B_{P O 4}=-\nabla P \cdot T+F w_{P O 4}-S_{P O 4} \quad \text { (Equation 6) } \\
& B_{\mathrm{SiO} 4}=-\nabla \mathrm{Si} \cdot \mathrm{T}+\mathrm{Fw}_{\mathrm{SiO} 4}-S_{\mathrm{SiO} 4} \quad \text { (Equation 7) }
\end{aligned}
$$


The B terms are the integrated top-to-bottom biogeochemical sinks, changes in the tracer concentrations by unit of time due to biogeochemical processes. The biogeochemical sink of DIC $\left(B_{D I C}\right)$ has two biological components: one related with organic matter $\left(B_{D_{I C}}\right)$ and another with production of $\mathrm{CaCO}_{3}\left(\mathrm{~B}_{\mathrm{CaCO}_{3}}\right)$ (Eq. 8).

$$
B_{D I C_{\text {org }}}+B_{\mathrm{CaCo}_{3}}=-\nabla D I C \cdot T+F W_{D I C}+F^{C O 2 \text { air-sea }}-S_{D I C} \quad \text { (Equation 8) }
$$

The central term in the model is $\mathrm{B}_{\mathrm{DIC}_{\text {org }}}$. Knowing $\mathrm{B}_{\mathrm{DIC}}$ org we can evaluate the sink in carbon mediated by changes in the pool of nutrients, oxygen and DIC during the net synthesis of organic matter using the stoichiometric relationships ( Takahashi et al. 1985; Anderson and Sarmiento, 1994).

$\mathrm{B}_{\mathrm{CaCO}_{3}}$ contributes to $\mathrm{B}_{\mathrm{Alk}}$ in the alkalinity equation (Eq. 3) because the main sink of alkalinity is the synthesis of $\mathrm{CaCO}_{3}$. Another sink of alkalinity $\left(\mathrm{B}_{\mathrm{Alk}}{ }_{\text {org }}\right)$ is due to organic matter oxidation, because $\mathrm{NO}_{3}, \mathrm{PO}_{4}$ and sulfate are produced during remineralization (Wolf-Gladrow et al., 2007). As a result, $\mathrm{B}_{\mathrm{Alk}}$ is a function of both $\mathrm{B}_{\mathrm{CaCO}_{3}}$ and $\mathrm{B}_{\mathrm{Alk}_{\text {org }}}$ (Eq. 9),

$$
B_{A l k_{\text {org }}}+2 B_{\mathrm{CaCO} 3}=-\nabla A l k \cdot T+F w_{A l k}-S_{A l k} \quad \text { (Equation 9) }
$$

where we used the stoichiometric relationship: one-unit decrease in $B_{\text {Alk }}$ corresponds to two units decrease in $\mathrm{B}_{\mathrm{CaCO}_{3}}$ (Wolf-Gladrow et al., 2007).

Knowing the stoichiometric ratios between elements, each biogeochemical sink $\left(\mathrm{B}_{\text {Tracer }}\right)$ can be related to the biological drawdown of organic carbon $\left(\mathrm{B}_{\mathrm{DIC}}{ }_{\text {org }}\right)$. The set of conservation equations 2-7 written as a function of $\mathrm{B}_{\mathrm{DIC}_{\text {org }}}$ reads:

$$
\begin{aligned}
& 0=-\nabla D I C \cdot T-B_{D I C_{\text {org }}}-B_{C a C O 3}+F w_{D I C}+F^{C O 2 \text { air-sea }}-S_{D I C} \quad \text { (Equation 10) } \\
& 0=-\nabla A l k \cdot T+r_{A T: N} r_{N: C} B_{D I C_{o r g}}-2 \cdot B_{C a C O 3}+F w_{A l k}-S_{A l k} \quad \text { (Equation 11) } \\
& 0=-\nabla O_{2} \cdot T-r_{O: C} B_{D I C_{o r g}}+F^{O 2 \text { air-sea }}-S_{O 2} \quad \text { (Equation 12) } \\
& 0=-\nabla N \cdot T-r_{N: C} B_{D I C_{o r g}}+F w_{N O 3}+A N D+N F-S_{N O 3} \quad \text { (Equation 13) } \\
& 0=-\nabla P \cdot T-r_{P: C} B_{D I C_{\text {org }}}+F W_{P O 4}-S_{P O 4} \quad \text { (Equation 14) } \\
& 0=-\nabla S i \cdot T-r_{S i: C} B_{D I C_{o r g}}+F w_{S i O 4}-S_{S i O 4} \quad \text { (Equation 15) }
\end{aligned}
$$

Besides tracer relationships, volume conservation is a mandatory constraint since volume needs to be balanced to avoid biogeochemical biases. Considering the box-model configuration 
previously defined (see section 2.1. and Fig.1), the net transport across the OVIDE section $\left(T^{\text {OVIDE }}\right)$ and the G-I-S Sills $\left(T^{\text {Sills }}\right)$, their components $\left(T^{\text {Irminger }}, T^{\text {ENA }}, T^{\text {WestSills }}, T^{\text {EastSills }}\right)$ and the volume transport across $\mathrm{RR}\left(T^{R R}\right)$ are interrelated in the volume conservation equations (Eq.16-18), along with the freshwater input via rivers and/or melting $\left(T^{f w}\right)$.

$$
\begin{aligned}
& 0=T^{\text {OVIDE }}-T^{\text {Sills }}+T^{f w}(\text { Equation } 16) \\
& 0=T^{\text {WestSills }}-T^{\text {Irminger }}+T^{R R}+T^{\text {Irminger }_{f w}}(\text { Equation } 17) \\
& 0=T^{\text {ENA }}-T^{\text {EastSills }}-T^{R R}+T^{E N A_{f w}} \quad \text { (Equation 18) }
\end{aligned}
$$

The aim of the model is to evaluate in a single procedure the following unknowns: the sinks/sources of DIC related with organic matter and $\mathrm{CaCO}_{3}\left(\mathrm{~B}_{\mathrm{DIC}}\right.$ org and $\mathrm{B}_{\mathrm{CaCO}_{3}}$ respectively) and the oxygen flux at the air-sea interface $\left(\mathrm{F}_{2}{ }^{\text {air-sea }}\right)$ subject to the volume and tracer constraints (Table 2). In addition, following Lherminier et al. (2010), we also optimized the volume transport across the sills (Table 2). Due to the box-model configuration, any biogeochemical variable $(B V)$ in the eSPNA is the sum of the estimates of IB and ENA:

$$
B V^{\text {eSPNA }}=B V^{I B}+B V^{E N A} \quad(\text { Equation 19) }
$$

With the tracer conservation equations defined for the three boxes (eSPNA, IB, ENA), the model configuration has 21 constraints (18 biogeochemical and 3 volume conservation equations) and 13 unknowns (6 biogeochemical unknowns - $\mathrm{B}_{\mathrm{DIC}_{\mathrm{org}}}, \mathrm{B}_{\mathrm{CaCO}_{3}}, \mathrm{~F}^{\mathrm{O}_{2}}$ air-sea for two boxes- and 7 water mass flux unknowns). Here we show the results when the model solves the biogeochemical unknowns for eSPNA and Irminger and infer the ENA magnitudes as the difference. The results are similar under different boxes configurations (Supp. Info A.3.).

The formulation of the inverse model is as follows: Given an a priori state of information for the unknowns (XO) and its associated error covariance matrix (C0), we define a set of constraints for the unknowns $(X)$ and its error covariance matrix $\left(\mathrm{C}_{\mathrm{t}}\right)$. The unknowns are listed in Table 2 along with their associated standard errors that were used to build $\mathrm{C} 0$, which was assumed to be diagonal. The set of constraints used in this work are a combination of biogeochemical (Equations 10-15 for each region) and volume conservation equations (Equations 16-18). The system is solved using a least-squares method to minimize a cost function (Eq. 20) in which the error covariance matrices are weighting factors. The unknowns solved by this method are consistent with both the a priori information $(X 0)$ and the formal constraints $f(X)=0$.

$$
\left(X-X_{0}\right)^{\prime} \cdot C_{0}^{-1} \cdot\left(X-X_{0}\right)+\left(f(X)^{\prime} \cdot C_{t}^{-1} \cdot f(X)\right) \quad(\text { Equation } 20)
$$


The reader interested in more details regarding the mathematical aspects is referred to Mercier, (1986) or M12.

Once presented the inverse model setup, the following sub-sections present 1) how the a priori values of the unknowns were selected, 2) how the known tracer transports terms of the constraints were computed and 3 ) how the uncertainties on the constraints were estimated.

\subsubsection{A priori selection criteria}

A priori information is explicitly used in our formulation of the inverse model, therefore it should be carefully selected (Mercier, 1986). The sources of the a priori state (X0) and error (C0) are detailed in Table 2.

There are three biogeochemical variables that are optimized by the procedure: $\mathrm{B}_{\mathrm{DIC}_{\text {org }}}, \mathrm{B}_{\mathrm{CaCO}_{3}}$ and $\mathrm{F}_{2} \mathrm{O}_{2}$ air-sea for each of the two boxes. $\mathrm{B}_{\mathrm{DIC}}$ org and $\mathrm{F}^{\mathrm{O}_{2}}$ air-sea where estimated for the same boxes by $\mathrm{M} 12$ and we used their values as a priori estimates.

To our knowledge, there are no estimates for $\mathrm{B}_{\mathrm{CaCO}_{3}}$ from top-to-bottom $\mathrm{CaCO}_{3}$ export budgets in our area. The closest approach is a synthesis of carbon fluxes to the ocean interior based on sediment trap data (Fig. 10, Honjo et al., 2008) that reported $\mathrm{CaCO}_{3}$ flux at $2000 \mathrm{~m}$ depth of $\sim 18$ $\mathrm{kmol} \cdot \mathrm{s}^{-1}$ for the whole eSPNA, which has a mean depth of 1940 meters. Without any information about how this sink is distributed between basins, it was evenly divided between IB and ENA (Table 2).

In order to improve the biogeochemical knowledge of the system, the error of the a priori information should reflect the state of knowledge about the magnitude. The relative error of the biogeochemical a priori magnitudes were set at $100 \%$ for the $\mathrm{B}_{\mathrm{DIC}_{\mathrm{org}}}$ and the $\mathrm{F}_{2} \mathrm{O}_{2}^{\text {air-sea }}$ and $200 \%$ for the $\mathrm{B}_{\mathrm{CaCO}_{3}}$, i.e., the range of error amplitude was defined as in $\mathrm{M} 12$. The influence of the a priori values and/or its range of errors in the model output was also assessed (Supp. Info Fig. S6-S7).

Along with the biogeochemical unknowns, volume fluxes of the water masses crossing the sills will also be optimised. The sources of information are given in Table 2. The model did not significantly modify the volume transports at the sills nor the errors from the original ones.

\subsubsection{Tracer transport computation}

At OVIDE, transports $\left(T_{\text {tracer }}^{O V I D E}\right)$ for each cruise and tracer were computed as in equation 21, 


$$
T_{\text {tracer }}^{\text {OVIDE }}=\int_{\text {Greenland }}^{\text {Portugal }} \int_{\text {bottom }}^{\text {surface }} v \cdot \rho_{\text {i.s. }} \cdot[\text { tracer }] d x d z \quad(\text { Equation 21) }
$$

combining the absolute velocity fields orthogonal to the section $(v)$ with interpolated tracer data from discrete bottle samples ([tracer]) (Supp. Info A.4.) and in situ densities $\left(\rho_{\text {i.s. }}\right)$. The horizontal coordinate $x$ follows the OVIDE section from Greenland $\left(60^{\circ} \mathrm{N}\right)$ to Portugal $\left(40^{\circ} \mathrm{N}\right), \mathrm{z}$ is the vertical coordinate. The vertical integration goes from surface to the bottom, and then net transports represent the full-depth water column.

The velocity fields across RR and at the G-I-S sills are not resolved. As a result, at the G-I-S sills the tracer transports were computed as the product of the volume transport $\left(T_{w m}^{s i l l s}\right)$, and the mean tracer concentration $\left(\overline{[\text { tracer }]_{w m}}\right)$ and density $\left(\overline{\rho_{w m}}\right)$ for each water mass (Eq. 22). The transports crossing the RR were computed as the product of the net volume transport $\left(T^{R R}\right)$, and the mean tracer concentration $\left(\overline{[\text { tracer }]_{R R}}\right)$, and density $\left(\overline{\rho_{R R}}\right)$ for the whole section (Eq.23):

$$
\begin{gathered}
T_{\text {tracer }}^{\text {sills }}=\sum_{w m=1}^{7} T_{w m}^{\text {sills }} * \overline{[\text { tracer }]_{w m}} * \overline{\rho_{w m}}(\text { Equation 22) } \\
T_{\text {tracer }}^{R R}=T^{R R} * \overline{[\text { tracer }]_{R R}} * \overline{\rho_{R R}}(\text { Equation } 23)
\end{gathered}
$$

The RR and Iceland allows splitting $T_{\text {tracer }}^{O V I D E}$ and $T_{\text {tracer }}^{\text {sills }}$ transports in $T_{\text {tracer }}^{\text {Irminger }} / T_{\text {tracer }}^{E N A}$ and $T_{\text {tracer }}^{\text {Westsill }} / T_{\text {tracer }}^{\text {EastSill }}$, respectively. Same as for OVIDE section transports, net transports are integrated over the full-depth water column.

Transports for OVIDE section are given in Table 8. All terms required for the estimates of transports across RR and at the G-I-S sills are given in Table 4. Hereinafter, positive (negative) numbers indicate northward (southward) transports.

The tracer transport divergences in Eq. 10-15 were estimated as:

$$
\begin{gathered}
\nabla \text { tracer } \cdot T^{\text {ESPNA }}=T_{\text {tracer }}^{\text {OVIDE }}-T_{\text {tracer }}^{\text {sills }}(\text { Equation 24) } \\
\nabla \text { tracer } \cdot T^{\text {Irminger }}=T_{\text {tracer }}^{\text {Irminger }}-T_{\text {tracer }}^{\text {Westlils }}+T_{\text {tracer }}^{\text {RR }}(\text { Equation 25) } \\
\nabla \text { tracer } \cdot T^{E N A}=T_{\text {tracer }}^{E N A}-T_{\text {tracer }}^{\text {Eastsills }}-T_{\text {tracer }}^{R R}(\text { Equation 26) }
\end{gathered}
$$

Uncertainties in the mean transports across OVIDE section were calculated as the standard error of the mean of the eight cruises over 2002-2016 (s.e. = std/ $\sqrt{8}$ ). At the G-I-S Sills and across RR, errors were computed using a perturbation method based on normally-distributed independent perturbations of transports and tracers $\left(n=10^{6}\right.$ for each input variable) generated 
using the uncertainties reported in Table 4 as standard deviations. To ensure volume conservation, the transport across the RR was recomputed for each set of perturbations.

\begin{tabular}{|c|c|c|c|c|}
\hline & & $\begin{array}{l}\text { Input a } \\
\text { priori }\end{array}$ & Source a priori & Output \\
\hline \multirow{3}{*}{$\begin{array}{c}\mathrm{B}_{\mathrm{DIC}_{\mathrm{org}}} \\
\left(\mathrm{kmol} \cdot \mathrm{s}^{-1}\right)\end{array}$} & eSPNA & $107 \pm 107$ & \multirow{3}{*}{ M12 } & $119 \pm 43$ \\
\hline & Irminger & $51 \pm 51$ & & $34 \pm 29$ \\
\hline & ENA & & & $85 \pm 52$ \\
\hline \multirow{3}{*}{$\begin{array}{c}\mathrm{B}_{\mathrm{CaCO}_{3}} \\
\left(\mathrm{kmol} \cdot \mathrm{s}^{-1}\right)\end{array}$} & eSPNA & $18 \pm 36$ & \multirow{3}{*}{ (Honjo et al., 2008) } & $49 \pm 31$ \\
\hline & Irminger & $9 \pm 18$ & & $9 \pm 18$ \\
\hline & ENA & & & $40 \pm 35$ \\
\hline \multirow{3}{*}{$\begin{array}{l}\mathrm{F}_{2}^{\mathrm{O}} \text { air-sea } \\
\left(\mathrm{kmol} \cdot \mathrm{s}^{-1}\right)\end{array}$} & eSPNA & $707 \pm 354$ & \multirow{3}{*}{ 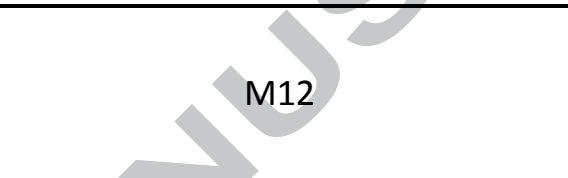 } & $807 \pm 114$ \\
\hline & Irminger & $264 \pm 528$ & & $292 \pm 102$ \\
\hline & ENA & & & $516 \pm 153$ \\
\hline \multirow{7}{*}{$\begin{array}{l}\text { Volume } \\
\text { Transport }^{\text {Sills }} \\
\text { (Sv) }\end{array}$} & $\mathrm{SV}_{\text {ENACW }}{ }^{\text {Sills }}$ & $3.9 \pm 0.5$ & ( $\varnothing$ sterhus et al., 2005$)$ & $3.93 \pm 0.42$ \\
\hline & $\mathrm{SV}_{\text {MNACW }}$ Sills & $3.9 \pm 0.5$ & (Østerhus et al., 2005) & $3.90 \pm 0.42$ \\
\hline & Sv $_{\text {ISOW }}$ Sills & $-1 \pm 0.5$ & (Hansen and $\varnothing$ sterhus, 2000) & $-1.00 \pm 0.42$ \\
\hline & $\mathrm{Sv}_{\text {ISOW2 }}{ }_{\text {Sills }}$ & $-2 \pm 0.3$ & (Hansen and $\varnothing$ sterhus, 2000) & $-2.00 \pm 0.28$ \\
\hline & $S v_{\text {NIII }}{ }^{\text {Sills }}$ & $0.88 \pm 0.13$ & (Jónsson and Valdimarsson, 2012) & $0.88 \pm 0.13$ \\
\hline & $\mathrm{SV}_{\mathrm{PW}}^{\text {sills }}$ & $-1.8 \pm 0.5$ & (Zunino et al., 2015) & $-1.84 \pm 0.32$ \\
\hline & Sv $_{\text {DSOW }}^{\text {Sills }}$ & $-3 \pm 0.4$ & (Macrander et al., 2005) & $-2.97 \pm 0.31$ \\
\hline \multicolumn{5}{|c|}{$\begin{array}{l}\text { ENACW: East North Atlantic Central Water, MNACW: Modified North Atlantic Central Water; } \\
\text { NIIW: North-Iceland Irminger Water; ISOW: Iceland-Scotland Overflow Water; PW: Polar Water; } \\
\text { DSOW: Denmark Strait Overflow Water. }\end{array}$} \\
\hline
\end{tabular}

\subsubsection{Uncertainties on the constraints}

The uncertainty on a constraint weights its influence in the solution. Uncertainties on the constraint were computed by error propagation as the square root of the sum of all squared errors for all known equation terms (Table 3). When the error of a term was not available, a $100 \%$ relative error amplitude was considered. In order to achieve volume conservation and not to bias biogeochemical equations, the uncertainty on volume conservation at the eSPNA was set to zero (Table 3, italic number). 
Table 3. Uncertainties on the constraints.

\begin{tabular}{|c|r|r|r|}
\hline $\begin{array}{c}\text { Uncertainty on the constraint } \\
\left(\mathrm{kmol} \cdot \mathrm{s}^{-1}\right)\end{array}$ & eSPNA & \multicolumn{1}{c|}{$\begin{array}{c}\text { Irminger } \\
\text { Basin }\end{array}$} & ENA \\
\hline DIC & 154 & 256 & 237 \\
\hline Alkalinity & 136 & 274 & 209 \\
\hline Oxygen & 109 & 111 & 181 \\
\hline Nitrate & 10.5 & 7.7 & 23.9 \\
\hline Phosphate & 0.9 & 0.8 & 1.9 \\
\hline Silicate & 17.4 & 10.9 & 51.3 \\
\hline Volume (Sv) & 0.00 & 5.2 & 5.2 \\
\hline
\end{tabular}

\subsection{Data ensemble}

\subsubsection{Velocity and tracer data}

Salinity, oxygen, nutrients and carbon variables along OVIDE were measured using the analytical procedures reported in García-lbáñez et al. (2015; 2016) and Fontela et al., (2016). Absolute geostrophic velocity field orthogonal to the OVIDE section was estimated using a linear box inverse model constrained by acoustic Doppler current profiler velocity measurements and by a net mass transport of $1 \pm 3 \mathrm{~Sv}$ to the north [see references in Table 1 for more information]. All OVIDE data are available from CLIVAR, Carbon Hydrographic Data Office (http://cchdo.ucsd.edul) and Seanoe (Sea scientific open data edition) (http://www.seanoe.org). Biogeochemical data at the G-I-S Sills and RR are based mainly on literature, public available datasets or our measurements (Table 2 and Table 4).

\begin{tabular}{|c|c|c|c|c|c|c|c|c|}
\hline Area & $\begin{array}{l}\text { Water } \\
\text { Mass }\end{array}$ & $\begin{array}{l}\text { Density } \\
\left(\mathrm{Kg}^{-} \mathrm{m}^{-}\right. \\
\left.{ }^{3}\right)^{1}\end{array}$ & $\mathrm{DIC}^{*}\left(\mu \mathrm{m} \cdot \mathrm{kg}^{-1}\right)^{1}$ & $\begin{array}{l}\text { Alkalinity } \\
\left(\mu \mathrm{m} \cdot \mathrm{kg}^{-1}\right)^{1}\end{array}$ & $\begin{array}{l}\mathrm{O}_{2} \\
\left(\mu \mathrm{m} \cdot \mathrm{kg}^{-1}\right)^{2}\end{array}$ & $\begin{array}{l}\mathrm{NO}_{3} \\
\left(\mu \mathrm{m} \cdot \mathrm{kg}^{-1}\right)^{2}\end{array}$ & $\begin{array}{l}\mathrm{PO}_{4} \\
\left(\mu \mathrm{m} \cdot \mathrm{kg}^{-1}\right)^{2}\end{array}$ & $\begin{array}{l}\mathrm{SiO}_{4} \\
\left(\mu \mathrm{m} \cdot \mathrm{kg}^{-1}\right)^{2}\end{array}$ \\
\hline \multirow{7}{*}{$\begin{array}{l}\text { ल } \\
\\
\text { क } \\
\text { का } \\
\frac{1}{\omega}\end{array}$} & ENACW & 1.0273 & $2127.2 \pm 20$ & $2325 \pm 7$ & $267.5 \pm 3$ & $11.9 \pm 0.4^{3}$ & $0.8 \pm 0.05^{3}$ & $4.5 \pm 0.5$ \\
\hline & MNACW & 1.0274 & $2132.9 \pm 22$ & $2323 \pm 6$ & $272 \pm 3^{3}$ & $13.7 \pm 0.4^{3}$ & $0.9 \pm 0.05^{3}$ & $5.85 \pm 0.5^{3}$ \\
\hline & ISOW1 & 1.0280 & $2160.1 \pm 5$ & $2304 \pm 8$ & $277.5 \pm 3$ & $16 \pm 0.4$ & $1.2 \pm 0.05$ & $12.5 \pm 0.5$ \\
\hline & ISOW2 & 1.0280 & $2166.4 \pm 3$ & $2303 \pm 3$ & $277.5 \pm 3$ & $16 \pm 0.4$ & $1.2 \pm 0.05$ & $12.5 \pm 0.5$ \\
\hline & NIIW & 1.0276 & $2144 \pm 3$ & $2309 \pm 2$ & $277.5 \pm 3$ & $14.8 \pm 0.4$ & $1.05 \pm 0.05$ & $7.5 \pm 0.5$ \\
\hline & PW & 1.0274 & $2118.7 \pm 8$ & $2266 \pm 3$ & $328 \pm 3$ & $12.1 \pm 0.4$ & $0.95 \pm 0.05$ & $7 \pm 0.5$ \\
\hline & DSOW & 1.0279 & $2152.6 \pm 6$ & $2294 \pm 5$ & $305 \pm 3$ & $13.8 \pm 0.4$ & $1.05 \pm 0.05$ & $9 \pm 0.5$ \\
\hline
\end{tabular}




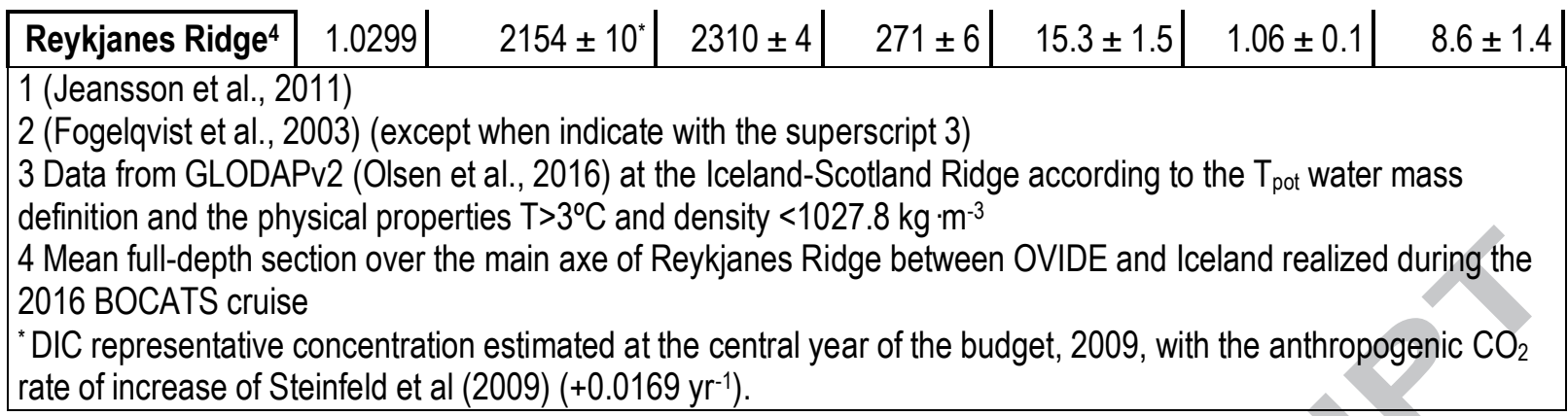

\subsubsection{Additional inputs and terms}

Air-sea exchange and freshwater supply terms required as input to Eqns. 10-15 and Eq. 27 are given in Table 5. More details about the additional terms can be found in the Supp. Info A.1.

Table 5. Additional inputs and terms in $\mathrm{kmol} \cdot \mathrm{s}^{-1}$ except for freshwater runoff (Sv).

\begin{tabular}{|c|c|c|c|c|c|}
\hline & \multirow[b]{2}{*}{ eSPNA } & \multirow[b]{2}{*}{$\begin{array}{c}\text { Irminger } \\
\text { Basin }\end{array}$} & & \multirow[b]{2}{*}{ Source } \\
\hline & & & & ENA & \\
\hline & $\begin{array}{l}\text { Freshwater } \\
\text { runoff (Sv) }\end{array}$ & 0.030 & $0.003^{1}$ & $0.027^{2}$ & $\begin{array}{r}{ }^{2} \text { Hawkings et al., (2017) } \\
\text { Center }\end{array}$ \\
\hline \multirow{5}{*}{$\begin{array}{l}\text { Flux from } \\
\text { rivers }\end{array}$} & DIC & 17.3 & 1.61 & 15.6 & \multirow{2}{*}{ Nondal et al., (2009)* } \\
\hline & Alkalinity & 17.3 & 1.61 & 15.6 & \\
\hline & Nitrate & 1.12 & 0.036 & 1.08 & \multirow{2}{*}{ Sharples et al., (2016) } \\
\hline & Phosphate & 0.095 & 0.002 & 0.094 & \\
\hline & Silicate & 4.69 & 0.44 & 4.25 & Dürr et al., (2011)* \\
\hline \multicolumn{2}{|c|}{$\begin{array}{c}\text { Atmospheric Nitrate } \\
\text { deposition }\end{array}$} & 1.36 & 0.22 & 1.14 & Yang and Gruber, (2016) \\
\hline \multicolumn{2}{|c|}{ Nitrogen fixation } & 5.42 & 0.39 & 5.03 & Jickells et al., (2017) \\
\hline \multicolumn{2}{|c|}{$\mathrm{F}^{\mathrm{CO} 2 \text { air-sea }}$} & $274 \pm 14$ & $56 \pm 3$ & $218 \pm 11$ & Rödenbeck et al., (2015)¥ \\
\hline
\end{tabular}

${ }^{*}$ Flux from rivers calculated with the tracer concentration $\left(\mu \mathrm{mol} \cdot \mathrm{kg}^{-1}\right)$ from the source along the freshwater runoff considered here

$¥$ Mean flux of $2002-2012$ referred to year 2009 using an annual rate of increase of $1.69 \%$ (Steinfeldt et al., 2009).

\subsubsection{Storage terms}

The storages of all tracers were estimated using OVIDE data and the total inventory time series (Pérez et al., 2010; Zunino et al., 2015). For each cruise and basin, an integrated tracer inventory for all the water masses and layers was estimated and the storage rate for 2002-2016 was estimated from a linear regression over the total inventories with time (Table 6). The errors on storage rates are the standard errors on the regression coefficients (Table 6). 


\begin{tabular}{|c|c|c|c|}
\hline \multicolumn{4}{|c|}{ Table 6. Basin tracer storages. } \\
\hline Storage rate $\left(\mathrm{kmol} \cdot \mathrm{s}^{-1}\right)$ & eSPNA & $\begin{array}{c}\text { Irminger } \\
\text { Basin }\end{array}$ & ENA \\
\hline DIC & $124 \pm 8^{p}$ & $25 \pm 5^{p}$ & $99 \pm 9^{p}$ \\
\hline Alkalinity & $-7 \pm 21$ & $6 \pm 3$ & $-13 \pm 21$ \\
\hline Oxygen & $56 \pm 27$ & $11 \pm 5$ & $45 \pm 28$ \\
\hline Nitrate & $-6 \pm 4$ & $-0.7 \pm 0.8$ & $-5 \pm 4$ \\
\hline Phosphate & $-0.3 \pm 0.6$ & $0.0 \pm 0.1$ & $-0.3 \pm 0.6$ \\
\hline Silicate & $1.5 \pm 5$ & $0.6 \pm 0.2$ & $0.9 \pm 5$ \\
\hline
\end{tabular}

\subsubsection{Stoichiometric ratios}

Following the stoichiometric ratios of Anderson and Sarmiento (1994), the formation of organic matter can be represented by a chemical equation (Eq. 27) with stoichiometric relationship between nutrients ( $\mathrm{N}$ and $\mathrm{P}$ ), oxygen and carbon:

$$
117 \mathrm{CO}_{2}+16 \mathrm{NO}_{3}{ }^{-}+\mathrm{PO}_{4}{ }^{3-}+55 \mathrm{H}_{2} \mathrm{O} \rightarrow\left(\mathrm{C}_{117} \mathrm{H}_{110} \mathrm{ON}_{16} \mathrm{P}\right)+170 \mathrm{O}_{2} \text { (Equation 27) }
$$

These stoichiometric relationships allow the conversion of $\mathrm{N}, \mathrm{P}$ or $\mathrm{O}_{2}$ consumptions to organic carbon units and vice versa. During the formation of the organic matter, there is a small increase in alkalinity equivalent to 1.36 units in $B_{N}$ (Wolf-Gladrow et al., 2007) $\left(r_{A T: N}=-\right.$ $\left.1.36 B_{N}\right)$. This increase can then be converted to carbon units in the same way as before (Anderson and Sarmiento, 1994) ( $\left.r_{\mathrm{N}}: r_{\mathrm{C}}, \mathrm{B}_{\mathrm{DIC}} \mathrm{org}\right)$.

In order to estimate the whole water column integrated biogeochemical sink, the choice of the stoichiometric ratios should reflect the net flux towards the sediment (Table 7 and references herein). Whereas the ratios $N: C, P: C, O: C$ and $A_{T}: N$ are relatively well established for the global synthesis and remineralization of the organic matter, the Si:C ratio is much more variable depending of the depth (Castro et al., 1998). The ratios of Si:C were estimated independently for each basin with the depth-dependent parameterization of Ragueneau et al. (2002) (Supp. Info A.2.). Remineralization ratios for carbon conversion between biogeochemical elements are included in the model, and an evaluation of their influence on the final output is included in the Results section (3.4.). 


\begin{tabular}{|c|c|c|}
\hline$r_{N: C}$ & $16: 117$ & $\begin{array}{l}\text { Anderson and Sarmiento, } \\
(1994)\end{array}$ \\
\hline$r_{P: C}$ & $1: 117$ & $\begin{array}{l}\text { Anderson and Sarmiento, } \\
\text { (1994) }\end{array}$ \\
\hline$r_{O: C}$ & $-170: 117$ & $\begin{array}{l}\text { Anderson and Sarmiento, } \\
\text { (1994) }\end{array}$ \\
\hline$r_{A T: N}$ & -1.36 & Wolf-Gladrow et al., (2007) \\
\hline$r_{S i: C}{ }^{e S P N A}$ & 0.20 & Ragueneau et al., (2002) \\
\hline$r_{S i: C}$ Irminger & 0.18 & Ragueneau et al., (2002) \\
\hline$r_{S i: C}{ }^{E N A}$ & 0.21 & Ragueneau et al., (2002) \\
\hline
\end{tabular}

\section{Results}

\subsection{Tracer transports and divergences}

The volume and tracer transports averaged over the eight cruises with their associated standard errors are reported in Table 8. Net volume transport at OVIDE section is $0.88 \pm 0.18 \mathrm{~Sv}$ northward. The transport of all tracers except oxygen are northward or almost zero $\left(\mathrm{NO}_{3}{ }^{-}, \mathrm{PO}_{4}{ }^{-}\right)$. On each side of the RR, net volume and tracer transports have opposite signs: They are negative (southwards) for the IB and positive (northwards) for the ENA. By combining tracer transports across OVIDE with the transports at G-I-S Sills and cross-RR, tracer transport divergences were obtained.

\begin{tabular}{|c|c|c|c|c|c|c|c|c|}
\hline & & Volume & DIC & Alkalinity & $\mathrm{O}_{2}$ & $\mathrm{NO}_{3}$ & $\mathrm{PO}_{4}$ & $\mathrm{SiO}_{4}$ \\
\hline \multirow{3}{*}{ 岁 } & $\begin{array}{l}\text { Whole } \\
\text { section }\end{array}$ & $0.88 \pm 0.18$ & $1968 \pm 413$ & $2619 \pm 444$ & $-909 \pm 132$ & $-0.04 \pm 6.2$ & $-0.8 \pm 0.7$ & $4.2 \pm 15$ \\
\hline & Irminger & $-16.2 \pm 3.7$ & $-35882 \pm 8331$ & $-38365 \pm 8902$ & $-5074 \pm 1058$ & $-246 \pm 62$ & $-16.4 \pm 3.7$ & $-145 \pm 38$ \\
\hline & ENA & $17.1 \pm 3.7$ & $37850 \pm 8221$ & $40984 \pm 8789$ & $4164 \pm 1018$ & $245 \pm 63$ & $15.5 \pm 4.1$ & $149 \pm 49$ \\
\hline
\end{tabular}




\subsection{Budgets}

The output of the model is presented in Table 2 and in Fig. 2. The mass, DIC, alkalinity, oxygen and nutrient budgets are described below. Sensitivity tests were performed in order to evaluate and validate the robustness of our results (Supp Info A.4.)

\subsubsection{Mass budget}

Volume is conserved in the whole domain (Fig 2A). The net northward transport at the OVIDE section of $0.88 \pm 0.18 \mathrm{~Sv}$ plus the freshwater input of $0.03 \mathrm{~Sv}$ from Greenland is balanced by the net northward transport through the G-SR. As a general depiction of the circulation, the flux across OVIDE section that is not exported into the Nordic Seas $(\sim 70 \%)$ is cyclonically recirculated in the subpolar gyre, crossing the RR westwards (12.3 $\pm 3.7 \mathrm{~Sv})$ towards the IB. The circulation pathways and the transport estimates are in agreement with Daniault et al. (2016).

\subsubsection{Dissolved inorganic carbon budget}

The net DIC transport into the eSPNA across OVIDE amounts to $1968 \pm 413 \mathrm{kmol} \cdot \mathrm{s}^{-1}$ and the transport across the G-SR is $1848 \pm 121 \mathrm{kmol} \cdot \mathrm{s}^{-1}$ (Fig 2B). There is a divergence of $-120 \pm 152$ $\mathrm{kmol} \cdot \mathrm{s}^{-1}$ for the whole eSPNA, distributed between ENA $\left(-105 \pm 236 \mathrm{kmol} \cdot \mathrm{s}^{-1}\right)$ and IB $(-15 \pm 256$ $\left.\mathrm{kmol} \cdot \mathrm{s}^{-1}\right)$. Air-sea exchange of $\mathrm{CO}_{2}$ represents an important source of DIC $\left(274 \pm 14 \mathrm{kmol} \cdot \mathrm{s}^{-1}\right)$. $\mathrm{DIC}$ is stored in the region at a rate of $124 \pm 8 \mathrm{kmol} \mathrm{s}^{-1}$.

\subsubsection{Alkalinity budget}

With the exception of the storage rates, the alkalinity budget is similar to the DIC budget: $2619 \pm$ $444 \mathrm{kmol} \cdot \mathrm{s}^{-1}$ of alkalinity goes northward into the eSPNA, while $2421 \pm 45 \mathrm{kmol} \cdot \mathrm{s}^{-1}$ are exported through the Nordic Seas (Fig 2C). The alkalinity divergence is $-198 \pm 134 \mathrm{kmol} \cdot \mathrm{s}^{-1}$, distributed between ENA $\left(-121 \pm 207 \mathrm{kmol} \cdot \mathrm{s}^{-1}\right)$ and IB $\left(-77 \pm 274 \mathrm{kmol} \cdot \mathrm{s}^{-1}\right)$. 

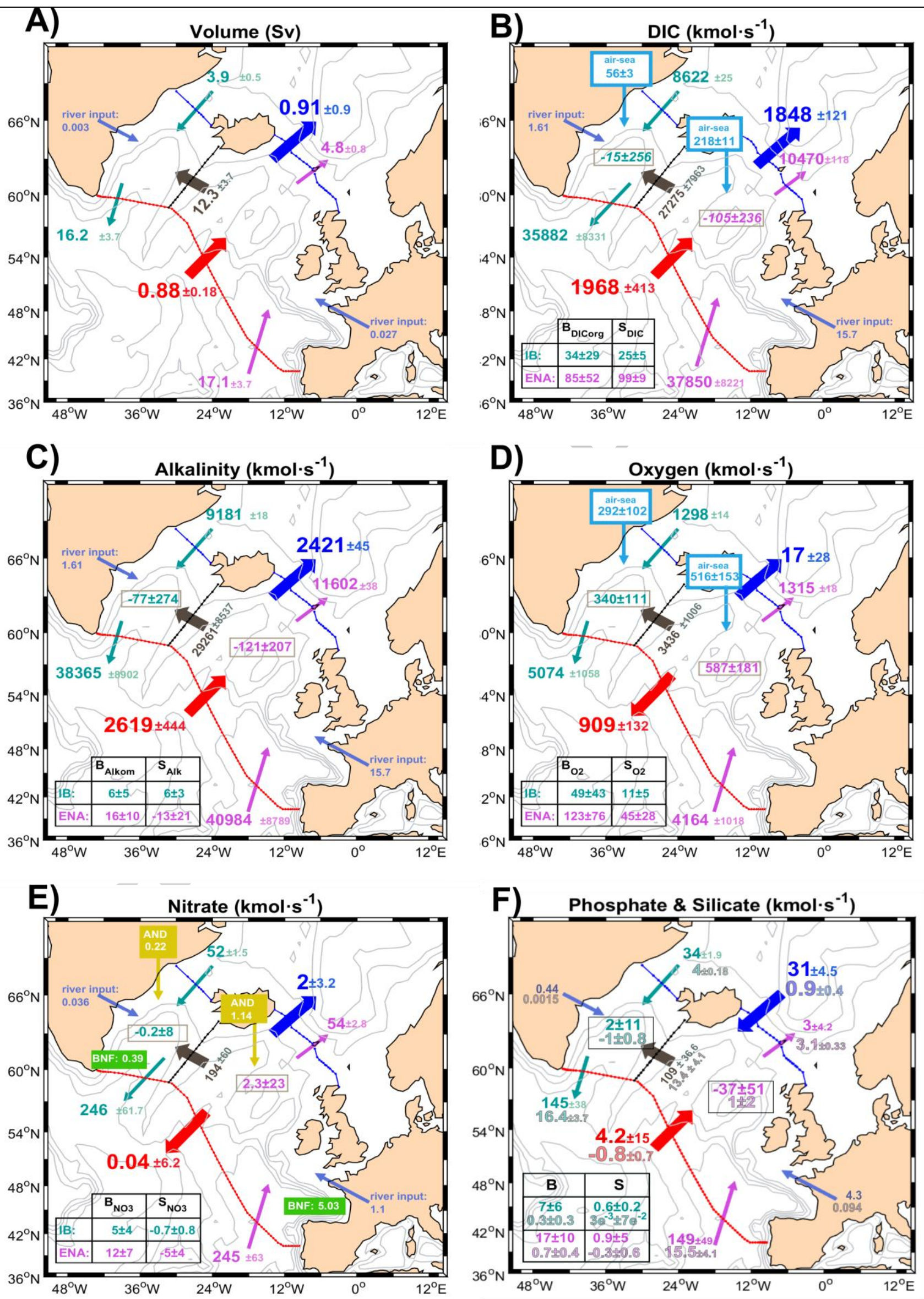
Figure 2. Budgets of A) Volume, B) Dissolved inorganic carbon (DIC), C) Alkalinity, D) Oxygen, E) Nitrate and F) Silicate and Phosphate. Arrows indicate net direction exclusively. The magnitude framed in the centre of each box is the tracer transport divergence. The biogeochemical sink and the storage rate for each tracer is reported in the lower left corner table. In the DIC and oxygen budget, the air-sea uptake is represented with the blue and white square. In the nitrate budget, due its relevance, atmospheric nitrogen deposition (AND) and the biological nitrate fixation (BNF) are represented with the yellow and the green square respectively. In subplot F) light numbers are for phosphate. Uncertainties are indicated.

\subsubsection{Oxygen budget}

At OVIDE, $4164 \pm 1018 \mathrm{kmol} \cdot \mathrm{s}^{-1}$ of oxygen flows into the ENA, while $-5074 \pm 1058 \mathrm{kmol} \cdot \mathrm{s}^{-1}$ goes out of the IB, so $909 \pm 132 \mathrm{kmol} \cdot \mathrm{s}^{-1}$ are exported toward southern latitudes (Fig. 2D). This export contrasts with the almost balanced situation at the G-SR. The net transport of oxygen at the G$\mathrm{SR}$, although very small, is even northward $\left(17 \pm 28 \mathrm{kmol} \cdot \mathrm{s}^{-1}\right)$. In the eSPNA, there is an important oxygen divergence of $927 \pm 109 \mathrm{kmol} \cdot \mathrm{s}^{-1}$, with a divergence at IB $\left(340 \pm 111 \mathrm{kmol} \cdot \mathrm{s}^{-1}\right)$ similar to that at ENA $\left(587 \pm 181 \mathrm{kmol} \cdot \mathrm{s}^{-1}\right)$ regardless the areal difference. Considering that storage rates for $\mathrm{O}_{2}$ (Table 6) are much smaller than divergences, the uptake of atmospheric $\mathrm{O}_{2}$ is considerable: $807 \pm 114 \mathrm{kmol} \cdot \mathrm{s}^{-1}$ for the whole eSPNA, distributed in $292 \pm 102 \mathrm{kmol} \cdot \mathrm{s}^{-1}$ in the IB and $516 \pm 153 \mathrm{kmol} \cdot \mathrm{s}^{-1}$ for the ENA.

\subsubsection{Nutrient budgets}

Net nitrate advection is virtually zero at OVIDE section $\left(-0.04 \pm 6.2 \mathrm{kmol} \cdot \mathrm{s}^{-1}\right)$, and slightly positive at the G-SR $\left(2 \pm 3.2 \mathrm{kmol} \cdot \mathrm{s}^{-1}\right)$ (Fig. $\left.2 \mathrm{E}\right)$. The input of nitrate includes external inputs: river advection, atmospheric deposition and nitrogen fixation; but with a different magnitude between ENA (total input by external sources: $\left.7.3 \mathrm{kmol} \cdot \mathrm{s}^{-1}\right)$ and IB $\left(0.64 \mathrm{kmol} \cdot \mathrm{s}^{-1}\right)$. For the phosphate (Fig. 2F), net transports are southwards and similar at OVIDE $\left(0.8 \pm 0.7 \mathrm{kmol} \cdot \mathrm{s}^{-1}\right)$ and at the G-SR $\left(0.9 \pm 0.4 \mathrm{kmol} \cdot \mathrm{s}^{-1}\right)$. As a result, the phosphate divergence is almost zero in the whole eSPNA $\left(-0.1 \pm 0.8 \mathrm{kmol} \cdot \mathrm{s}^{-1}\right)$. Magnitudes of silicate transports are larger compared with the other nutrients (Fig. 2F), and at OVIDE there is a net transport of $4.2 \pm 15 \mathrm{kmol} \cdot \mathrm{s}^{-1}$. This northward advection, even with an important error, contrasts with the southward transport of 31 $\pm 4.5 \mathrm{kmol} \cdot \mathrm{s}^{-1}$ of silicate at the G-SR. This results in a transport convergence for silicate of $35 \pm$ $17 \mathrm{kmol} \cdot \mathrm{s}^{-1}$ mainly originating in the ENA $\left(-37 \pm 51 \mathrm{kmol} \cdot \mathrm{s}^{-1}\right)$.

\subsection{Biogeochemical estimates optimized by the model.}

The model estimated the net biogeochemical production of organic $\left(119 \pm 43 \mathrm{kmol} \cdot \mathrm{s}^{-1}\right)$ and inorganic carbon $\left(\sim \mathrm{CaCO}_{3}, 49 \pm 31 \mathrm{kmol} \cdot \mathrm{s}^{-1}\right)$, and an air-sea oxygen uptake $\left(807 \pm 114 \mathrm{kmol} \cdot \mathrm{s}^{-1}\right)$ for the whole area (Table 2). Estimates of $\mathrm{B}_{\mathrm{DIC}_{\text {org }}}, \mathrm{B}_{\mathrm{CaCO}_{3}}$ and $\mathrm{F}_{2}$ air-sea for ENA are larger than for $\mathrm{IB}$, but the contribution of the IB to the total magnitude is larger than it would be, based only on 
its areal proportion. The IB, representing $16 \%$ of the total area in the eSPNA, is the place where almost $29 \%$ of organic carbon export occurs. The IB contribution to the oxygen uptake is also remarkable (36\%).

\subsection{Model Sensitivity:}

In order to evaluate the sensitivity of the model, a set of tests modifying the stoichiometric ratios or the a priori conditions have been performed:

\subsubsection{Modifying the stoichiometric ratios}

We conducted a sensitivity study by modifying the stoichiometric ratios between the main components of organic matter, the nitrogen:carbon ratio $\left(r_{\mathrm{N}: \mathrm{C}}\right)$, the phosphorus:carbon $\left(\mathrm{r}_{\mathrm{P}: \mathrm{C}}\right)$ and the oxygen:carbon $\left(r_{\mathrm{O}: \mathrm{c}}\right)$. We kept constant the ratio silicate:carbon $\left(r_{\mathrm{Si}: \mathrm{c}}\right)$, which is depthdependent and was integrated inside the model with different values for each region (Supp. Info A.2.), and the ratio between the change in total alkalinity and nitrogen $\left(r_{A T: N}\right)$ as well. The ranges of variation for the ratios were within the theoretical limits of marine organic matter composition (Fraga et al., 1998). Although the model does show a sensitivity to the ratios (Fig. 3), especially to $\mathrm{r}_{\mathrm{N}: \mathrm{C}}$ and $\mathrm{r}_{\mathrm{P}: \mathrm{C}}$, it is within the range of the uncertainty of model output. A revision of the stoichiometric ratios to takes into account the anthropogenic carbon influence has been made for the North Atlantic (Körtzinger et al., 2001b). Using these ratios (C:N:P:-O=123:17:1:-165), the output of the model remains practically identical (Fig.3). The model assumes that there is no time varying changes in elemental stoichiometries during 2002-2016. Given the results of this sensitivity study, it is unlikely that this assumption significantly affects the results. 

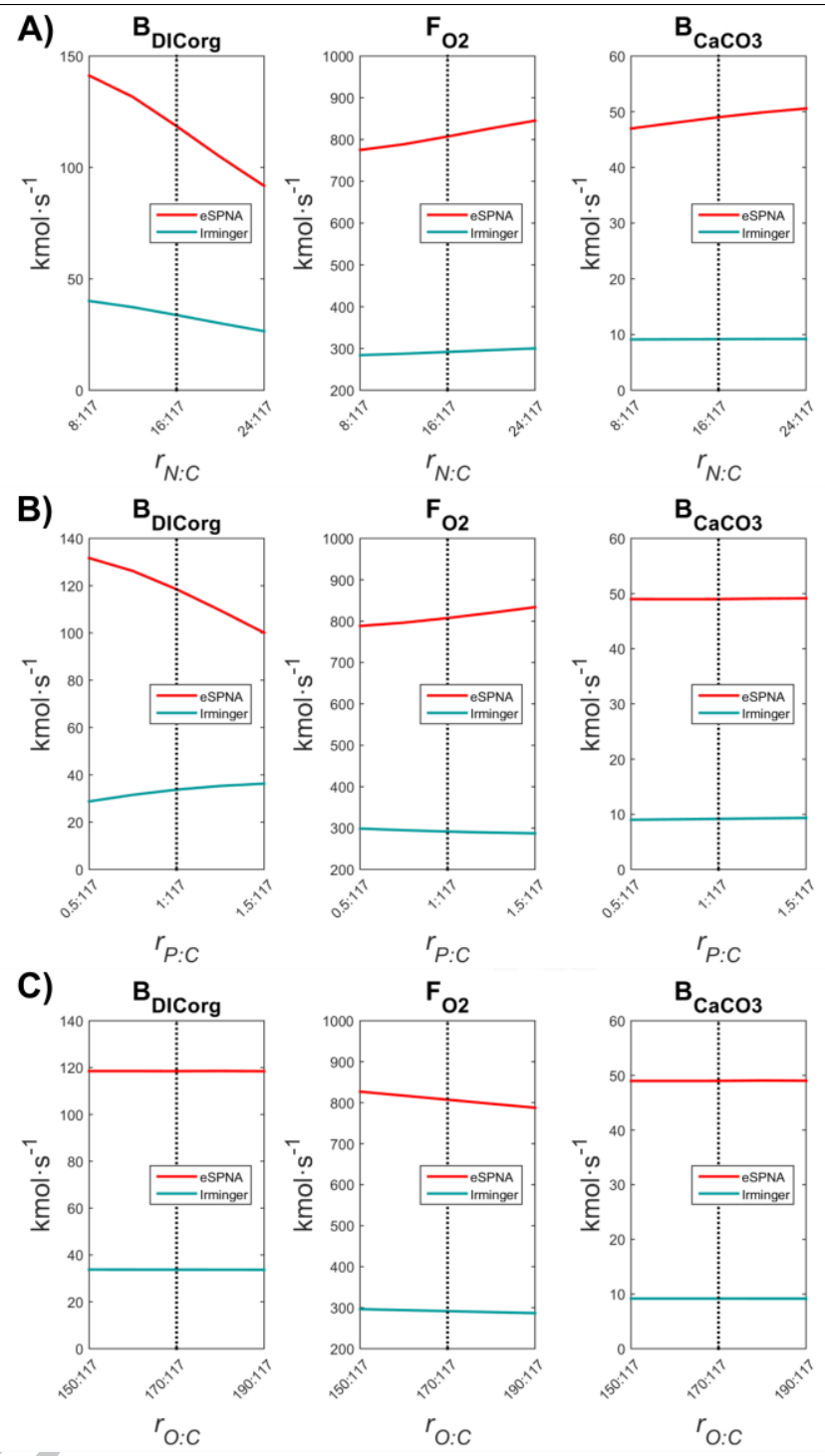

Figure 3. Changes in the model outputs for eSPNA (red) and IB (blue) (y-axis, $\left.\mathrm{kmol} \cdot \mathrm{s}^{-1}\right)$ as a function of changes in the stoichiometric ratios (x-axis) A) $\left.r_{\mathrm{N}: \mathrm{C}}, \mathrm{B}\right) \mathrm{r}_{\mathrm{P}: \mathrm{C}}$ and C) $\mathrm{r}_{\mathrm{O}: \mathrm{C}}$. Vertical black dashed line is the stoichiometric ratio used in the reference model.

\subsubsection{Modifying the a priori values and/or their errors}

Our inverse formalism requires a priori values representing the state of knowledge about the biological parameters before inversion. In order to evaluate the robustness of the outputs with regard to the a priori values and associated errors, we tested the sensitivity of the unknowns in response to changes in the a priori values. 
Fig. 4 shows the change in the estimate of each biogeochemical unknown when a single a priori value is modified in the range 0 to $250 \mathrm{kmol} \cdot \mathrm{s}^{-1}$ for $\mathrm{B}_{\mathrm{DICorg}}$ and $\mathrm{B}_{\mathrm{CaCO}_{3}}$ and in the range 0 to 2500 $\mathrm{kmol} \cdot \mathrm{s}^{-1}$ for the $\mathrm{F}^{\mathrm{O}_{2}}$ air-sea . The error on the a priori value was modified as well to keep the same proportion between a priori error and a priori estimate as in the original model. The output shows an interplay between $\mathrm{B}_{\mathrm{DI}}$ org and $\mathrm{F}_{2} \mathrm{O}_{2}^{\text {air-sea }}$, when one increases, the other decreases. The change in $\mathrm{B}_{\mathrm{CaCO}_{3}}$ (last row of Fig. 4), does not affect neither $\mathrm{B}_{\mathrm{DICorg}}$ nor $\mathrm{F}^{\mathrm{O}_{2}}$ air-sea , but shows linear response with itself. This indicates the minor weight that $\mathrm{B}_{\mathrm{CaCO}_{3}}$ has on the final output. We conclude that the a priori choice was adequate and reflects the balance between the two main biogeochemical unknowns of the model: $\mathrm{B}_{\mathrm{DICorg}}$ and $\mathrm{F}^{\mathrm{O}_{2}}$ air-sea . We also tested if the change in the error associated with each a priori value has significant impact in the final output. We keept constant the a priori magnitude for the unknowns and changed the errors. As shown in Fig. 4 (dashed lines), the output is closer to the a priori value when smaller a priori errors are used. In summary, even though our unknowns show some dependence on the a priori values and/or its range of errors, we do not find large sensitivity. This gives us confidence that our biogeochemical estimates are robust. 

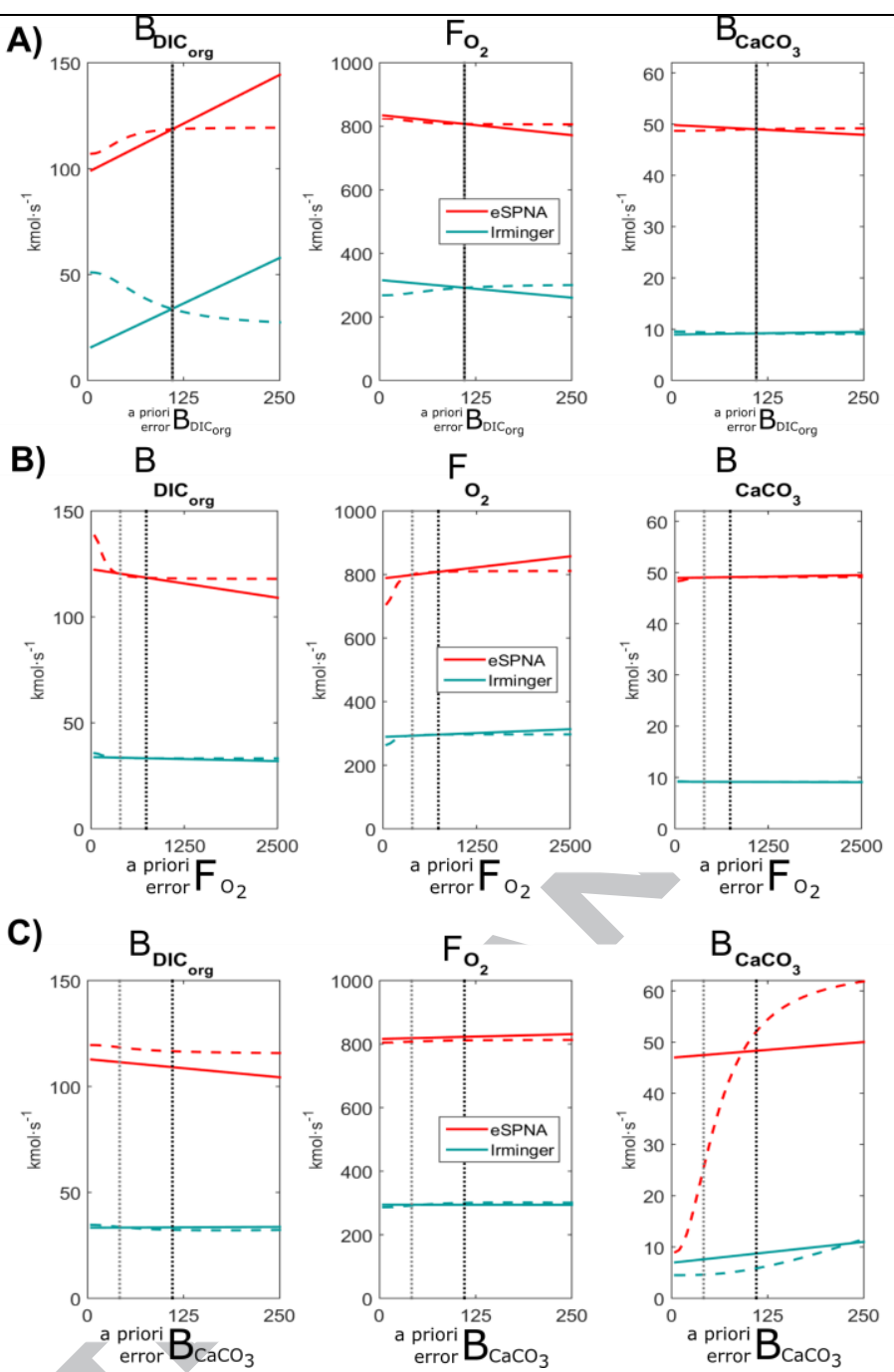

Figure 4. Changes in the model outputs for the eSPNA (red) and IB (blue) (y-axis, $\mathrm{kmol} \cdot \mathrm{s}^{-1}$ ) with respect to the initial a priori value/error (solid line/ dotted line) ( $\mathrm{x}$-axis, $\mathrm{kmol} \cdot \mathrm{s}^{-1}$ ) of $\mathrm{A}$ ) $\mathrm{B}_{\text {DICorg }}$, B) $\mathrm{F}^{\mathrm{O} 2 \text { air-sea }}$ and C) $\mathrm{B}_{\mathrm{CaCO}}$. Vertical black (grey) dashed line is the a priori value (error) used in the reference model. 


\section{Discussion}

Previous studies of carbon related budgets in the subpolar North Atlantic were limited to either nitrate, phosphate and oxygen budgets (M12) or DIC (Z15). In this study, we combined M12 and Z15 approach, more specifically,

1) the assessment of carbon, oxygen and nutrient budgets together related through stoichiometric ratios allows the derivation of fully consistent budgets. In M12 there were no carbon variables and in Z15 neither oxygen nor nutrients. It is the first time that alkalinity, the macronutrient silicate and the carbonate export $\left(\mathrm{E}_{\mathrm{CaCO}_{3}}\right)$ are included.

2) The temporal range is longer (2002-20016) than in M12 (2002-2006) and Z15 (20022010) leading to more robust estimates of fluxes across OVIDE. The uncertainties in oceanic tracer transports and divergences are significantly reduced through the averaging of repeated sections (Ganachaud and Wunsch, 2002). Precisely, the number of cruises (8) in this longer temporal range allows the evaluation of storage rates for all tracers in each basin instead of being assumed zero, and they were included in the model.

3) In addition to using the WOA climatology (Garcia et al., 2013; Garcia et al., 2013b) for biogeochemical tracers along the RR and G-SR as in $\mathrm{M} 12$, we used observational $\mathrm{CO}_{2}$ system data from GLODAPv2 (Olsen et al., 2016) and data from measurements above the RR during a recent cruise (29AH20160617). These observations and the climatological data have produced independent and consistent tracer transports above the RR and G-SR.

4) Additional inputs with potential to alter biogeochemical cycles were included in the model: freshwater inputs, atmospheric deposition and biological fixation.

Before proceeding with individual budgets descriptions, it is important to remark the significance of our integrated approach. An estimate of biogeochemical terms exclusively based on the budget of a single element (e.g. Z15) could be inconsistent with estimates coming from other budgets. This optimization method based on an over-determined system of interrelated biogeochemical constraints solves the budgets together, ensuring the consistency between the estimated variables and the full set of biogeochemical equations. Here, all biogeochemical budgets were satisfied within the uncertainty imposed. The final optimized biogeochemical sink term obtained from solving the full system of biogeochemical equations is not the same as it would be if computed separately: the organic carbon sink in the eSPNA would had been $~ 80 \%$ larger if estimated from DIC or silicate budgets alone; it would have been practically the same if 
estimated only with oxygen budget, and it would have been $~ 85 \%$ smaller if estimated from nitrate or phosphate budgets.

As expected, the model shows sensitivity to the stoichiometric ratios that interrelate the biogeochemical constraints (Fig. 3). Regardless, taken into account the theoretical limits of elemental composition (Fraga et al., 1998), the output for the sinks are within the range of the uncertainties on the biogeochemical estimates optimized by the model.

\subsection{Dissolved inorganic carbon}

For the eSPNA, the budget of DIC for the period 2002-2016 is consistent with Pérez et al. (2013) and Z15. The DIC transports are intrinsically related with volume transports, and the variability in DIC transport at intradecadal scale depends on the variability of volume transport (Z15). Carbon-laden waters from subtropical latitudes that reach the eSPNA are already saturated in anthropogenic carbon (Pérez et al., 2013). Around a third of the DIC that enters the eSPNA via ENA crosses the G-SR, becoming the principal input of DIC to the Nordic Seas (Fig. 2B) (Jeansson et al., 2011). A previous inorganic carbon budget in the North Atlantic found a notable southward transport of DIC for section WOCE A25 (-1015 $\left.\pm 490 \mathrm{kmol} \cdot \mathrm{s}^{-1}\right)$ (Álvarez et al., 2003). These results were based on a net southward flux of volume (-0.4 $\pm 1.5 \mathrm{~Sv}$ ) forced by an inverse method who ensured salt conservation instead of mass (Álvarez et al., 2003). Our results based on eight repeats of OVIDE show that inorganic carbon is unequivocally transported northward in the subpolar North Atlantic ( $p$-value<0.002).

The storage rate for the period 2002-2016 (Table 6, $124 \pm 8 \mathrm{kmol} \cdot \mathrm{s}^{-1}$ ) is similar to those found by Z15 for 2002-2010 (158 $\left.\pm 36 \mathrm{kmol} \cdot \mathrm{s}^{-1}\right)$ and by Tanhua and Keeling, (2012) for 1980-2005 $\left(113 \pm 34 \mathrm{kmol} \cdot \mathrm{s}^{-1}\right)$. Our basin-scale approach to the total inventories includes the whole water column, not only the first two thousand meters (Tanhua and Keeling, 2012), and the number of repetitions of OVIDE section (8) gives more confidence in the storage trend ( $p$-value<0.001).

The air-sea flux of $\mathrm{CO}_{2}, \mathrm{~F}^{\mathrm{CO}_{2} \text { air-sea }}$, was computed (Supp. info A.1.1.) using SOCOM (Rödenbeck et al., 2015). The uptake was estimated at $274 \pm 14 \mathrm{kmol} \cdot \mathrm{s}^{-1}$ (Table 5). The magnitude of the uptake is clearly higher than the magnitude used in Z15 $\left(164 \pm 53 \mathrm{kmol} \cdot \mathrm{s}^{-1}\right)$ that was based on Takahashi et al. (2009). There is a positive trend for $\mathrm{CO}_{2}$ uptake in the eSPNA since the 2000's (Fig.S2) and the $\mathrm{CO}_{2}$ sink has been strengthened in the subpolar North Atlantic as well as at global scale (Landschützer et al., 2016). Noting that the DIC transports and $\mathrm{S}_{\text {DIC }}$ are here similar to those in Z15, and that $\mathrm{F}^{\mathrm{CO}_{2}}$ air-sea increased, a $\mathrm{B}_{\mathrm{DIC}}$ org larger than in Z15 (113 $\left.\pm 103 \mathrm{kmol} \cdot \mathrm{s}^{-1}\right)$ would be expected. The use of interrelated biogeochemical conservation equations inside the 
model shows here its relevance. A solution exclusively dependent on the DIC budget, would have closed the balance with greater export terms and a large error bar. Our estimate based on all relevant biogeochemical budgets is more robust (smaller error bar) while being compatible with all equations as well. With an optimized output for $\mathrm{B}_{\mathrm{DIC}}$ org of $119 \pm 43 \mathrm{kmol} \cdot \mathrm{s}^{-1}$, the eSPNA is confirmed as an important sink of inorganic carbon.

\subsection{Alkalinity}

To the best of our knowledge, this is the first time that an alkalinity budget is derived in the subpolar North Atlantic. Alkalinity transports and divergences are close in magnitude and behavior to those of DIC. Salty waters with high alkalinities are advected by the North Atlantic Current (NAC) inside the ENA. Along their path in the subpolar gyre, NAC water masses progressively freshen (Subpolar Mode Water at $8^{\circ} \mathrm{C}$ and $7^{\circ} \mathrm{C}$ and Subarctic Intermediate Water at $\left.6^{\circ} \mathrm{C}\right)$, and alkalinity diminishes.

Overall, the model shows a not significant alkalinity imbalance for the eSPNA $(\sim 145 \pm 174$ $\mathrm{kmol} \cdot \mathrm{s}^{-1}$ ). Alkalinity budget is known to be closely dependent of the salt budget (Millero et al., 1998; Lee et al., 2006). Applying the general conservation equation (Eq. 1) to salinity for the period 2002-2016 confirms that the salt budget is balanced within uncertainties, but the strong relationship between salt and alkalinity makes that small salinity residuals could be responsible for an important fraction ( $60 \%)$ of the not significant alkalinity imbalance.

\subsection{Oxygen cycle}

Southward export of oxygen from high latitudes has long been recognized (Gruber et al., 2001; Bopp et al., 2002) but published estimates of North Atlantic oxygen transports span a considerable range of values: $-924 \pm 314 \mathrm{kmol} \cdot \mathrm{s}^{-1}$ at OVIDE section (M12), $-1992 \pm 440 \mathrm{kmol} \cdot \mathrm{s}^{-1}$ at WOCE A25 (Álvarez et al., 2002), -1750 $\pm 500 \mathrm{kmol} \cdot \mathrm{s}^{-1}$ at 47ㅇN (Ganachaud and Wunsch, 2002). Apparently, this southward transport increases towards the Equator with larger oxygen southward transports at 24ํN: $-2070 \pm 600 \mathrm{kmol} \cdot \mathrm{s}^{-1}$ (Ganachaud and Wunsch, 2002) and -2621 $\pm 705 \mathrm{kmol} \cdot \mathrm{s}^{-1}$ (Lavín et al., 2003). The NAC transports subtropical waters poor in oxygen inside the eSPNA and across the Iceland-Scotland Ridge. The inputs of highly oxygenated water masses from the Nordic Sea: overflows (ISOW, DSOW) and Polar Water (PW) balance the outflow of less oxygenated waters advected by the NAC and there is no net oxygen transport at the G-SR because there is a net transport of $0.91 \pm 0.9 \mathrm{~Sv}$ northward.

During the cyclonic recirculation in the eSPNA and their returning south as a Deep Western Boundary Current (DWBC) in the IB, the NAC waters are cooled and transformed by convection 
processes. Both surface cooling (thermal effect) and convection (mixing) imply oxygenation (Bopp et al., 2002), leading to the export of $909 \pm 132 \mathrm{kmol} \cdot \mathrm{s}^{-1}$ of oxygen from the eSPNA. The magnitude is comparable with that for the period 2002-2006 (M12), and is relatively constant among cruises.

The model finds an uptake of oxygen of $807 \pm 114 \mathrm{kmol} \cdot \mathrm{s}^{-1}$ for the whole eSPNA, greater than the a priori value, which was set to the air-sea oxygen flux estimated by M12 $\left(707 \pm 96 \mathrm{kmol} \cdot \mathrm{s}^{-}\right.$ $\left.{ }^{1}\right)$. The uptake is notably larger than proposed in air-sea $\mathrm{O}_{2}$ fluxes climatologies (Najjar and Keeling, 2000) while being in agreement with the mean annual oxygen uptake of $\sim 7 \mathrm{~mol} \cdot \mathrm{m}^{-2} \cdot \mathrm{yr}^{-1}$ $\left(840 \mathrm{kmol} \cdot \mathrm{s}^{-1}\right)$ in the North polar Atlantic found in an ocean biogeochemical model (Bopp et al., 2002). The net uptake is $292 \pm 102 \mathrm{kmol} \cdot \mathrm{s}^{-1}$ in the IB and $516 \pm 153 \mathrm{kmol} \cdot \mathrm{s}^{-1}$ in the ENA. In the $\mathrm{IB}$, the uptake is dominated by the mixed layer depth oxygenation and the regular deep convection events that occurs in the Irminger Sea (de Jong and de Steur, 2016; Fröb et al., 2016; Piron et al., 2017). In addition to air-sea uptake, there is a net production of oxygen through photosynthesis (Eq. 12) that was estimated to $49 \pm 43 \mathrm{kmol} \cdot \mathrm{s}^{-1}$ for the IB and $123 \pm 76$ $\mathrm{kmol} \cdot \mathrm{s}^{-1}$ for the ENA. This oxygen uptake mediated by biology sets the eSPNA as a net autotrophic region.

Air-sea oxygen flux is controlled both by $\mathrm{O}_{2}$ solubility (thermal effect) and circulation processes (dynamical effect) (Bopp et al., 2002; Keeling et al., 2010). Dissolved $\mathrm{O}_{2}$ in seawater equilibrates so fast with the atmosphere that a heat uptake will cause an oxygen release and vice versa (Sarmiento and Gruber, 2004). Assigning a maximum air-sea $\mathrm{O}_{2}$ flux of $\sim 1500$ $\mathrm{kmol} \cdot \mathrm{s}^{-1}$.for each PW $\left(10^{15} \mathrm{~W}\right)$ of heat released (Holfort et al., 1998), the uptake of $\mathrm{O}_{2}$ found here, $848 \pm 107 \mathrm{kmol} \cdot \mathrm{s}^{-1}$, would represent a heat loss of $0.56 \pm 0.07 \mathrm{PW}$. This magnitude is in agreement with the mean northward heat transport observed in OVIDE in the period 2002-2010, $0.47 \pm 0.05 \mathrm{PW}$, and with the 2014 cruise $(0.56 \pm 0.06 \mathrm{PW})$. Heat transport across OVIDE was due mainly to the overturning circulation (Mercier et al., 2015, Zunino et al., 2017). The main agent for heat and oxygen redistribution in the ESPNA is the AMOC.

\subsection{Nutrients}

There are some studies about nutrient transport across North Atlantic sections (Álvarez et al., 2002; Ganachaud and Wunsch, 2002; Lavín et al., 2003; Maze et al., 2012; Torres-Valdés et al., 2013). Using data from WOCE, Ganachaud and Wunsch, (2002) found transports of $-130 \pm$ $50 \mathrm{kmol} \cdot \mathrm{s}^{-1}, 10 \pm 35 \mathrm{kmol} \cdot \mathrm{s}^{-1}$ and $1.1 \pm 2.5 \mathrm{kmol} \cdot \mathrm{s}^{-1}$ for silicate, nitrate and phosphate, respectively, at $47^{\circ} \mathrm{N}$. A section near OVIDE reported a southward export of $-26 \pm 15 \mathrm{kmol} \cdot \mathrm{s}^{-1}$, $50 \pm 19 \mathrm{kmol} \cdot \mathrm{s}^{-1}$ and $-6 \pm 2 \mathrm{kmol} \cdot \mathrm{s}^{-1}$ for silicate, nitrate and phosphate, respectively (Álvarez et 
al., 2002). The nutrient transports reported by M12 for OVIDE section in 2002-2006 are compatible within errors with our estimates. M12 found $11 \pm 16 \mathrm{kmol} \cdot \mathrm{s}^{-1}$ and $0.2 \pm 1 \mathrm{kmol} \cdot \mathrm{s}^{-1}$ for nitrate and phosphate, respectively, compared with $-0.04 \pm 6.2 \mathrm{kmol} \cdot \mathrm{s}^{-1}$ and $-0.8 \pm 0.7 \mathrm{kmol} \cdot \mathrm{s}^{-1}$ here.

At the northern limit of the eSPNA, an Arctic budget (Torres-Valdés et al., 2013) led to estimates of nutrient fluxes through the Fram Strait and the Barents Sea Opening (BSO). The fluxes of silicate, nitrate and phosphate in the northward direction were $6.2 \pm 6 \mathrm{kmol} \cdot \mathrm{s}^{-1}, 23.3 \pm 9 \mathrm{kmol} \cdot \mathrm{s}^{-1}$ and $1.5 \pm 0.9 \mathrm{kmol} \cdot \mathrm{s}^{-1}$, respectively. There are important differences between these estimates and the fluxes shown here for the G-SR. The difference for nitrate is more than $20 \mathrm{kmol} \cdot \mathrm{s}^{-1}$, and almost $40 \mathrm{kmol} \cdot \mathrm{s}^{-1}$ for silicate. Torres-Valdés et al. (2013) estimates were based on a single summer cruise (year 2005). The range of nutrient transports for the eight repetitions of the OVIDE section spans $\sim 6.5 \mathrm{kmol} \cdot \mathrm{s}^{-1}$ for phosphate, $\sim 49 \mathrm{kmol} \cdot \mathrm{s}^{-1}$ for nitrate and $\sim 114 \mathrm{kmol} \cdot \mathrm{s}^{-1}$ for silicate showing a large variability in these fluxes. A budget constructed with a single cruise can be quite different from the mean. Using eight repetitions of the section in the model smooths out monthly to interannual variability. Even under the reasonable assumption that the variability in volume is smaller in the Arctic gateways influenced by Atlantic water, a unique repetition may not represent the mean state. Furthermore, the net northward transport across G-SR reported here $(0.91 \mathrm{~Sv})$, is less than the net northward transport across Fram Strait and BSO reported in Torres-Valdés et al. (2013) (2 Sv). Their greater northward transport involves additional sources of nutrients from the Baltic Sea and/or the continental runoff (Jeansson et al., 2011).

There is agreement between the nitrate budget (Fig. 2E) and the budget published for the period 2002-2006 (Fig. 2A in M12). The differences in the transport divergence values are related with the inclusion of more cruises and the interannual transport variability, but they are not significant given the amplitude of error bars. M12 noted that the top-to-bottom eastern side of the OVIDE section (ENA-OVIDE face) was richer in nitrate than the other faces, causing a nitrate convergence. We did not observe this due to two complementary explanations. First, we used measured data and not climatology data (M12) at the RR and the G-SR. Second, the amount of subtropical poor-nutrient waters reaching the ENA has become more important since the beginning of the 2000's due to the weakening of the subpolar gyre (Johnson et al., 2013).

The silicate budget (Fig. 2F) is strongly conditioned by the dissimilar content in silicate of the northern- and southern-origin water masses. The silicate input from the south in the ENA circulates across the RR westward and then southward in the IB. The vertical distribution of silicate in the ocean shows a typical profile of lower concentrations in the upper layers 
increasing with depth, so deep-sea basins shows the higher concentrations in silicate. The advection of silicate cross-RR is conditioned by the mean depth of the ridge, less than $1500 \mathrm{~m}$ in the deepest point considered here, so the mean concentration advected for silicate $(8.6 \pm 0.1$ $\mu \mathrm{mol} \cdot \mathrm{kg}^{-1}$, Table 4 ) is representative of intermediate layers.

Seasonal cycle in the biological activity in relationship to primary production could result in seasonal variations of the nutrient concentrations. To quantify the effect of seasonal variability, winter conditions were simulated in the surface layer. The output of the model is inside the range of the uncertainties of our reference solution and the main conclusions are the same (Supp. Info A.4.4.).

\subsection{Fate of DIC sink}

Our findings support the existence of an important carbon sink created by biological drawdown of DIC in the eSPNA. This result agrees within uncertainties with the export magnitude found by nutrient consumption (M12) and DIC budgets (Z15). Once detected and quantified, what can we infer about the fate of that DIC sink? Following the biogeochemical interrelationships between oceanic carbon pools, we propose three alternative but not mutually exclusive pathways for the carbon sink: (i) it is exported out of the region as DOC, (ii) it is channelled through particulate carbon production (POC/PIC), or (iii) it is accumulated in the sediments. The low concentrations in POC and PIC in comparison with the DIC and DOC pools in the eSPNA (at least two orders of magnitude less than DIC) (Le Moigne et al., 2013; Ceballos-Romero et al., 2016; Puigcorbé et al., 2017; Lemaitre et al., 2018) leads to the conclusion that the main DIC sink cannot be in POC and PIC pools.

In autotrophic systems, as is the eSPNA, a net production of DOC is expected (Hansell and Carlson, 1998). So, it is tempting to suggest that the DIC sink is being exported south of OVIDE section in form of DOC as an excess of non-refractory DOC (Carlson et al., 2010; Fontela et al., 2016). Recently, Fontela et al. (2016) using modelled DOC concentrations along OVIDE section got an insignificant net production of DOC in the eSPNA $\left(8 \pm 77 \mathrm{kmol} \cdot \mathrm{s}^{-1}\right)$. This means that the modelled DOC budget did not support the general rule of net production of DOC in autotrophic systems, however, it has a large uncertainty $\left(77 \mathrm{kmol} \cdot \mathrm{s}^{-1}\right)$. So, with that uncertainty, we can't preclude the existence of an effective DOC export from the eSPNA as part of the organic

carbon sink found here $\left(B_{D_{I I}}{ }_{o r g}, 119 \mathrm{kmol} \cdot \mathrm{s}^{-1}\right)$. In the southward flow of the lower limb of the AMOC from OVIDE section towards subtropical latitudes the remineralization of DOC supposes the $\sim 30 \%$ of Atlantic Ocean oxygen consumption (Fontela et al., 2016). This contribution to the 
oxygen consumption is already in the upper range (5-29\%) proposed by other authors (Carlson et al., 2010). Then, if the fate of the net DIC sink would be the southward export as DOC from the eSPNA, the contribution of DOC remineralization to the oxygen consumption from subpolar to subtropical latitudes would be much greater than expected from the current literature.

The last alternative pathway for the sink would be a net export into the sediments. A global parameterization for the carbon export to the sediments based on a least squares fit to sediment traps observations, gives values in the range $200-1000 \mathrm{mmol} \cdot \mathrm{m}^{-2} \cdot \mathrm{yr}^{-1}$ for the organic fraction and in the range $100-200 \mathrm{mmol} \cdot \mathrm{m}^{-2} \cdot \mathrm{yr}^{-1}$ for the inorganic at $2000 \mathrm{~m}$ depth (Figure 9 and 10 in Honjo et al., (2008)). This flux toward the sediment would be between 24-120 kmol. $\mathrm{s}^{-1}$ for the organic fraction and 12-24 kmol.s ${ }^{-1}$ of carbon in $\mathrm{CaCO}_{3}$. The mean depth of the eSPNA is $\sim 1940$ meters. Thus, our estimate for the organic fraction $\left(119 \pm 43 \mathrm{kmol} \cdot \mathrm{s}^{-1}\right)$ is in agreement with the upper range of Honjo et al. (2008) parameterization while it is larger $\left(49 \pm 31 \mathrm{kmol} \cdot \mathrm{s}^{-1}\right)$ for the inorganic fraction. Recently, the representativeness of sediment traps has been discussed due the potentially non negligible contribution of slow-sinking particles $\left(<100 \mathrm{~m} \cdot \mathrm{d}^{-1}\right)$ to the total flux (Alonso-Gonzalez et al., 2010; Riley et al., 2012; Villa-Alfageme et al., 2014, 2016; Baker et al., 2017). The contribution of slowly settling particles is not accounted for in models of export based in deep sediment traps like the model of Honjo et al. (2008). Our box-model budget comprehends the whole-water column, so the potential additional contribution to carbon burial mediated by slow-sinking particles is also included in our estimates. We suggest that the net export of particles into the sediments is the reason behind the large values found here.

\section{Conclusions}

Using an inverse box model constrained by biogeochemical relationships, the biogeochemical budget of dissolved inorganic carbon, alkalinity, dissolved oxygen, nitrate, phosphate and silicate were estimated in the eSPNA. The combination of 8 repetitions spanning 14 years of the high-quality hydrographic section OVIDE with public available data sources allows the assessment of biogeochemical cycles in an integrated budget model. This physicobiochemical coupling of information based on transports allows a quantitative evaluation independent of assumptions about biogeochemical behaviour and with an output consistent between tracers.

On decadal time scale, this biogeochemical budget establishes that the region acts as an important dissolved inorganic carbon sink. The eSPNA is a net autotrophic region where biological primary production exceeds respiration and with an organic (inorganic) carbon export of $119 \pm 43 \mathrm{kmol} \cdot \mathrm{s}^{-1}\left(49 \pm 31 \mathrm{kmol} \cdot \mathrm{s}^{-1}\right)$. The connection of the northward upper limb with the 
southward lower limb of the AMOC mediated by deep water formation processes lead to tracer export. We suggest that light-to-dense water formation processes associated with deep convection events and mixed layer depth oxygenation in the eSPNA are the reason for the oxygen uptake $\left(807 \pm 114 \mathrm{kmol} \cdot \mathrm{s}^{-1}\right)$, and that the transport of high-oxygen waters in the lower limb of the AMOC is the principal mechanism for the southward flux of oxygen. The Irminger Sea, located at the confluence of the two limbs of the AMOC is a hotspot for tracers to be longtime sequestered in the deep ocean; it represents $26 \%$ and $18 \%$ of the organic and inorganic carbon export, respectively, and $36 \%$ of oxygen uptake, while being $16 \%$ of the total eSPNA area.

With increasing atmospheric $\mathrm{CO}_{2}$ levels, the assumption that the biological carbon cycle is in steady state would require further evaluation. The combination of observations coming from different methodologies and the exploitation of open access databases along with modelling efforts, allowed to analyze carbon fluxes in a dynamical region within an integrated approach. The large results presented here for carbon export and oxygen uptake are in agreement with the upper range of previous observations based on different methods. These results have to be accounted to constrain global ocean carbon models and can be taken as a baseline in future evaluations of carbon cycle in the North Atlantic.

\section{Acknowledgments}

The authors are grateful to the Captains, crew, technicians and scientists for their support during all the OVIDE cruises. We thank all who contributed to the acquisition and data analysis. The OVIDE research project was co-funded by the IFREMER, CNRS/INSU/LEFE. This study is a contribution to AtlantOS project funded by the European Union's Horizon 2020 research and innovation programme under grant agreement No. 516 633211, and a contribution to the project BOCATS (CTM2013-41048-P) supported by the Spanish Ministry of Economy and Competitiveness and co-funded by the Fondo Europeo de Desarrollo Regional 2014-2020 (FEDER). For this work M. Fontela was funded by the Spanish Ministry of Economy and Competitiveness (BES-2014-070449). H. Mercier was supported by the CNRS and the ATLANTOS project (GA 633211). We thank H. Ducklow and X. A. Álvarez-Salgado for revision of the manuscript.

\section{References}

Alonso-Gonzalez, I.J., Aristegui, J., Lee, C., Sanchez-Vidal, A., Calafat, A., Fabres, J., Sangra, P., Masque, P., Hernandez-Guerra, A., Benitez-Barrios, V., 2010. Role of slowly settling particles in the ocean carbon cycle. Geophys. Res. Lett. 37, 1-5. 
doi:10.1029/2010GL043827

Álvarez, M., Bryden, H.L., Pérez, F.F., Ríos, A.F., Roson, G., 2002. Physical and biogeochemical fluxes and net budgets in the subpolar and temperate North Atlantic. J. Mar. Res. 60, 191-226. doi:10.1357/00222400260497462

Álvarez, M., Ríos, A.F., Pérez, F.F., Bryden, H.L., Rosón, G., 2003. Transports and budgets of total inorganic carbon in the subpolar and temperate North Atlantic. Global Biogeochem. Cycles 17, 2-1-2-21. doi:10.1029/2002GB001881

Anderson, L.A., Sarmiento, J.L., 1994. Redfield ratios of remineralization determined by nutrient data analysis. Global Biogeochem. Cycles. doi:10.1029/93GB03318

Baker, C.A., Henson, S.A., Cavan, E.L., Giering, S.L.C., Yool, A., Gehlen, M., Belcher, A., Riley, J.S., Smith, H.E.K., Sanders, R., 2017. Slow Sinking Particulate Organic Carbon in the Atlantic Ocean: magnitude, flux and potential controls. doi:10.1002/2017GB005638

Behrenfeld, M.J., Falkowski, P.G., 1997. Photosynthetic rates derived from satellite-based chlorophyll concentration. Limnol. Oceanogr. 42, 1-20. doi:10.4319/lo.1997.42.1.0001

Bopp, L., Que, C. Le, Heimann, M., Manning, A.C., Monfray, P., 2002. Climate-induced oceanic oxygen fluxes : Implications for the contemporary carbon budget. Global Biogeochem. Cycles 16, 1022-1035. doi:10.1029/2001gb001445

Broecker, W.S., Peng, T.H., 1982. Tracers in the sea, Lamont-Doherty Geological Observatory. doi:10.1016/0016-7037(83)90075-3

Carlson, C.A., Hansell, D.A., Nelson, N.B., Siegel, D.A., Smethie, W.M., Khatiwala, S., Meyers, M.M., Halewood, E., 2010. Dissolved organic carbon export and subsequent remineralization in the mesopelagic and bathypelagic realms of the North Atlantic basin. Deep. Res. Part II Top. Stud. Oceanogr. 57, 1433-1445. doi:10.1016/j.dsr2.2010.02.013

Carr, M.-E., Friedrichs, M.A.M., Schmeltz, M., Noguchi Aita, M., Antoine, D., Arrigo, K.R., Asanuma, I., Aumont, O., Barber, R., Behrenfeld, M., Bidigare, R., Buitenhuis, E.T., Campbell, J., Ciotti, A., Dierssen, H., Dowell, M., Dunne, J., Esaias, W., Gentili, B., Gregg, W., Groom, S., Hoepffner, N., Ishizaka, J., Kameda, T., Le Quéré, C., Lohrenz, S., Marra, J., Mélin, F., Moore, K., Morel, A., Reddy, T.E., Ryan, J., Scardi, M., Smyth, T., Turpie, K., Tilstone, G., Waters, K., Yamanaka, Y., 2006. A comparison of global estimates of marine primary production from ocean color. Deep Sea Res. Part II Top. Stud. Oceanogr. 53, 741770. doi:10.1016/j.dsr2.2006.01.028

Castro, C.G., Pérez, F.F., Holley, S.E., Ríos, A.F., 1998. Chemical characterisation and modelling of water masses in the Northeast Atlantic. Prog. Oceanogr. doi:10.1016/S00796611(98)00021-4

Ceballos-Romero, E., Le Moigne, F.A.C., Henson, S., Marsay, C.M., Sanders, R.J., Garc??aTenorio, R., Villa-Alfageme, M., 2016. Influence of bloom dynamics on Particle Export Efficiency in the North Atlantic: a comparative study of radioanalytical techniques and sediment traps. Mar. Chem. 186, 198-210. doi:10.1016/j.marchem.2016.10.001

Daniault, N., Mercier, H., Lherminier, P., Sarafanov, A., Falina, A., Zunino, P., Pérez, F.F., Ríos, A.F., Ferron, B., Huck, T., Thierry, V., Gladyshev, S., 2016. The northern North Atlantic Ocean mean circulation in the early 21 st century. Prog. Oceanogr. 146, 142-158. 
doi:10.1016/j.pocean.2016.06.007

de Jong, M.F., de Steur, L., 2016. Strong winter cooling over the Irminger Sea in winter 20142015, exceptional deep convection, and the emergence of anomalously low SST. Geophys. Res. Lett. 43, 7106-7113. doi:10.1002/2016GL069596

Ducklow, H.W., Steinberg, D.K., Buesseler, K.O., 2001. Upper Ocean Carbon Export and the Biological Pump. Oceanography 14, 50-58. doi:10.5670/oceanog.2001.06

Dunne, J.P., Sarmiento, J.L., Gnanadesikan, A., 2007. A synthesis of global particle export from the surface ocean and cycling through the ocean interior and on the seafloor. Global Biogeochem. Cycles 21,1-16. doi:10.1029/2006GB002907

Dürr, H.H., Meybeck, M., Hartmann, J., Laruelle, G.G., Roubeix, V., 2011. Global spatial distribution of natural riverine silica inputs to the coastal zone. Biogeosciences 8, 597-620. doi:10.5194/bg-8-597-2011

Eakins, B.W., Sharman, G.F., 2010. Volumes of the World's Oceans from ETOPO1, NOAA National Geophysical Data Center, Boulder, CO, 2010. [WWW Document]. NOAA Natl. Geophys. Data Center, Boulder, CO. URL https://www.ngdc.noaa.gov/mgg/global/etopo1_ocean_volumes.html (accessed 1.5.18).

Falkowski, P.G., Barber, R.T., Smetacek, V., 1998. Biogeochemical controls and feedbacks on ocean primary production. Science (80-. ). 281, 200-206.

doi:10.1126/science.281.5374.200

Fay, A.R., McKinley, G.A., 2014. Global open-ocean biomes: Mean and temporal variability. Earth Syst. Sci. Data. doi:10.5194/essd-6-273-2014

Fogelqvist, E., Blindheim, J., Tanhua, T., Buch, E., Rey, F., 2003. Greenland-Scotland over ow studied by hydro-chemical multivariate analysis. Atlantic 50, 73-102.

Fontela, M., García-lbáñez, M.I., Hansell, D.A., Mercier, H., Pérez, F.F., 2016. Dissolved Organic Carbon in the North Atlantic Meridional Overturning Circulation. Sci. Rep. 6, 26931. doi:10.1038/srep26931

Fraga, F., Rios, A.F., Perez, F.F., Figueiras, F.G., 1998. Theoretical limits of oxygen : carbon and oxygen : nitrogen ratios during photosynthesis and mineralisation of organic matter in the sea. Sci. Mar. 62, 161-168. doi:10.3989/scimar.1998.62n1-2161

Fröb, F., Olsen, A., Våge, K., Moore, G.W.K., Yashayaev, I., Jeansson, E., Rajasakaren, B., 2016. Irminger Sea deep convection injects oxygen and anthropogenic carbon to the ocean interior. Nat. Commun. 7, 13244. doi:10.1038/ncomms13244

Ganachaud, A., Wunsch, C., 2002. Oceanic nutrient and oxygen transports and bounds on export production during the World Ocean Circulation Experiment. Global Biogeochem. Cycles 16, 5-1-5-14. doi:10.1029/2000GB001333

García-lbáñez, M.I., Pardo, P.C., Carracedo, L.I., Mercier, H., Lherminier, P., Ríos, A.F., Pérez, F.F., 2015. Structure, transports and transformations of the water masses in the Atlantic Subpolar Gyre. Prog. Oceanogr. 135, 18-36. doi:10.1016/j.pocean.2015.03.009

García-ibáñez, M.I., Zunino, P., Fröb, F., Carracedo, L.I., Ríos, A.F., Mercier, H., 2016. Ocean acidification in the subpolar North Atlantic : rates and mechanisms controlling $\mathrm{pH}$ changes 
3701-3715. doi:10.5194/bg-13-3701-2016

Garcia, H.E., Boyer, T.P., Locarnini, R.A., Antonov, J.I., Mishonov, A. V, Baranova, O.K., Zweng, M.M., Reagan, J.R., Johnson, D.R., 2013. World Ocean Atlas 2013. Volume 3: dissolved oxygen, apparent oxygen utilization, and oxygen saturation. NOAA Atlas NESDIS 75.

Garcia, H.E., Locarnini, R.A., Boyer, T.P., Antonov, J.I., Baranova, O.K., Zweng, M.M., Reagan, J.R., Johnson, D.R., 2013. World Ocean Atlas 2013, Volume 4 : Dissolved Inorganic Nutrients (phosphate, nitrate, silicate), NOAA Atlas NESDIS 76. doi:10.1182/blood-201106-357442

Gourcuff, C., Lherminier, P., Mercier, H., Le Traon, P.Y., 2011. Altimetry combined with hydrography for ocean transport estimation. J. Atmos. Ocean. Technol. 28, 1324-1337. doi:10.1175/2011JTECHO818.1

Gruber, N., Gloor, M., Fan, S.M., Sarmiento, J.L., 2001. Air-sea flux of oxygen estimated from bulk data: Implications for the marine and atmospheric oxygen cycles. Global Biogeochem. Cycles 15, 783-803. doi:10.1029/2000GB001302

Guidi, L., Chaffron, S., Bittner, L., Eveillard, D., Larhlimi, A., Roux, S., Darzi, Y., Audic, S., Berline, L., Brum, J., Coelho, L.P., Espinoza, J.C.I., Malviya, S., Sunagawa, S., Dimier, C., Kandels-Lewis, S., Picheral, M., Poulain, J., Searson, S., Coordinators, T.O., Stemmann, L., Not, F., Hingamp, P., Speich, S., Follows, M., Karp-Boss, L., Boss, E., Ogata, H., Pesant, S., Weissenbach, J., Wincker, P., Acinas, S.G., Bork, P., de Vargas, C., ludicone, D., Sullivan, M.B., Raes, J., Karsenti, E., Bowler, C., Gorsky, G., 2015. Plankton networks driving carbon export in the oligotrophic ocean. Nature 532, in review. doi:10.1038/nature16942

Hansell, D.A., Carlson, C.A., 1998. Net Community Production of dissolved organic carbon. Global Biogeochem. Cycles 12, 443-453.

Hansen, B., Østerhus, S., 2000. North Atlantic Nordic Seas Exchanges. Prog. Oceanogr. 45, 109-208. doi:10.1016/S0079-6611(99)00052-X

Hartman, S.E., Larkin, K.E., Lampitt, R.S., Lankhorst, M., Hydes, D.J., 2010. Seasonal and inter-annual biogeochemical variations in the Porcupine Abyssal Plain 2003-2005 associated with winter mixing and surface circulation. Deep. Res. Part II Top. Stud. Oceanogr. 57, 1303-1312. doi:10.1016/j.dsr2.2010.01.007

Hawkings, J.R., Wadham, J.L., Benning, L.G., Hendry, K.R., Tranter, M., Tedstone, A., Nienow, P., Raiswell, R., 2017. Ice sheets as a missing source of silica to the polar oceans. Nat. Commun. 8, 14198. doi:10.1038/ncomms 14198

Henson, S.A., Sanders, R., Madsen, E., 2012. Global patterns in efficiency of particulate organic carbon export and transfer to the deep ocean. Global Biogeochem. Cycles 26, 1-14. doi:10.1029/2011GB004099

Henson, S.A., Yool, A., Sanders, R., 2015. Variability in efficiency of particulate organic carbon export: A model study. Global Biogeochem. Cycles 33-45. doi:10.1002/2014GB004965.Received

Holfort, J., Johnson, K.M., Schneider, B., Siedler, G., Wallace, D.W.R., 1998. Meridional 
transport of dissolved inorganic carbon in the South Atlantic Ocean. Global Biogeochem. Cycles 12, 479-499.

Honjo, S., Manganini, S.J., Krishfield, R.A., Francois, R., 2008. Particulate organic carbon fluxes to the ocean interior and factors controlling the biological pump: A synthesis of global sediment trap programs since 1983. Prog. Oceanogr. 76, 217-285. doi:10.1016/j.pocean.2007.11.003

Jeansson, E., Olsen, A., Eldevik, T., Skjelvan, I., Omar, A.M., Lauvset, S.K., Nilsen, J.E.Ø., Bellerby, R.G.J., Johannessen, T., Falck, E., 2011. The Nordic Seas carbon budget: Sources, sinks, and uncertainties. Global Biogeochem. Cycles 25, 1-16. doi:10.1029/2010GB003961

Jickells, T.D., Buitenhuis, E., Altieri, K., Baker, A.R., Capone, D., Duce, R.A., Dentener, F., Fennel, K., Kanakidou, M., LaRoche, J., Lee, K., Liss, P., Middelburg, J.J., Moore, J.K., Okin, G., Oschlies, A., Sarin, M., Seitzinger, S., Sharples, J., Singh, A., Suntharalingam, P., Uematsu, M., Zamora, L.M., 2017. A reevaluation of the magnitude and impacts of anthropogenic atmospheric nitrogen inputs on the ocean. Global Biogeochem. Cycles 31 , 289-305. doi:10.1002/2016GB005586

Johnson, C., Inall, M., Häkkinen, S., 2013. Declining nutrient concentrations in the northeast Atlantic as a result of a weakening Subpolar Gyre. Deep. Res. Part I Oceanogr. Res. Pap. 82, 95-107. doi:10.1016/j.dsr.2013.08.007

Jónsson, S., Valdimarsson, H., 2012. Water mass transport variability to the North Icelandic shelf, 19942010. ICES J. Mar. Sci. doi:10.1093/icesjms/fss024

Keeling, R.F., Körtzinger, A., Gruber, N., 2010. Ocean Deoxygenation in a Warming World. Ann. Rev. Mar. Sci. 2, 199-229. doi:10.1146/annurev.marine.010908.163855

Körtzinger, A., Hedges, J.I., Quay, P.D., 2001. Redfield ratios revisited: Removing the biasing effect of anthropogenic CO2. Limnol. Oceanogr. doi:10.4319/lo.2001.46.4.0964

Körtzinger, A., Koeve, W., Kähler, P., Mintrop, L., 2001. C : N ratios in the mixed layer during the productive season in the northeast Atlantic Ocean. Deep. Res. Part I Oceanogr. Res. Pap. 48, 661-688. doi:10.1016/S0967-0637(00)00051-0

Lampitt, R.S., Salter, I., de Cuevas, B.A., Hartman, S., Larkin, K.E., Pebody, C.A., 2010. Longterm variability of downward particle flux in the deep northeast Atlantic: Causes and trends. Deep. Res. Part II Top. Stud. Oceanogr. 57, 1346-1361. doi:10.1016/j.dsr2.2010.01.011

Landschützer, P., Gruber, N., Bakker, D.C.E., 2016. Decadal variations and trends of the global ocean carbon sink. Global Biogeochem. Cycles 30, 1396-1417. doi:10.1002/2015GB005359

Lavín, A.M., Bryden, H.L., Parrilla, G., 2003. Mechanisms of heat, freshwater, oxygen and nutrient transports and budgets at $24.5^{\circ} \mathrm{N}$ in the subtropical North Atlantic. Deep. Res. Part I Oceanogr. Res. Pap. 50, 1099-1128. doi:10.1016/S0967-0637(03)00095-5

Laws, E., Falkowski, P.G., Smith, W.O., Ducklow, H.W., McCarthy, J.J., 2000. Temperature effects on export production in the open ocean. Global Biogeochem. Cycles 14, 12311246. doi:10.1029/1999GB001229

Le Moigne, F.A.C., Henson, S.A., Sanders, R.J., Madsen, E., 2013. Global database of surface 
ocean particulate organic carbon export fluxes diagnosed from the 234Th technique. Earth Syst. Sci. Data 5, 295-304. doi:10.5194/essd-5-295-2013

Lee, K., Tong, L.T., Millero, F.J., Sabine, C.L., Dickson, A.G., Goyet, C., Park, G.H., Wanninkhof, R., Feely, R.A., Key, R.M., 2006. Global relationships of total alkalinity with salinity and temperature in surface waters of the world's oceans. Geophys. Res. Lett. 33. doi:10.1029/2006GL027207

Legendre, L., Rivkin, R.B., Weinbauer, M.G., Guidi, L., Uitz, J., 2015. The microbial carbon pump concept: Potential biogeochemical significance in the globally changing ocean. Prog. Oceanogr. 134, 432-450. doi:10.1016/j.pocean.2015.01.008

Lemaitre, N., Planchon, F., Planquette, H., Dehairs, F., Fonseca-Batista, D., Roukaerts, A., Deman, F., Tang, Y., Mariez, C., Sarthou, G., 2018. High variability of export fluxes along the North Atlantic GEOTRACES section GA01: Particulate organic carbon export deduced from the \&amp;it;sup\&amp;gt;234\&amp;lt;/sup\&amp;gt;Th method. Biogeosciences Discuss. 1-38. doi:10.5194/bg-2018-190

Lherminier, P., Mercier, H., Gourcuff, C., Alvarez, M., Bacon, S., Kermabon, C., 2007. Transports across the 2002 Greenland-Portugal Ovide section and comparison with 1997 112, 1-20. doi:10.1029/2006JC003716

Lherminier, P., Mercier, H., Huck, T., Gourcuff, C., Perez, F.F., Morin, P., Sarafanov, A., Falina, A., 2010. The Atlantic Meridional Overturning Circulation and the subpolar gyre observed at the A25-OVIDE section in June 2002 and 2004. Deep. Res. Part I Oceanogr. Res. Pap. 57, 1374-1391. doi:10.1016/j.dsr.2010.07.009

Longhurst, A., Sathyendranath, S., Platt, T., Caverhill, C., 1995. An estimate of global primary production in the ocean from satelite radiometer data. J. Plankton Res. 17, 1245-1271.

Lozier, M.S., Leadbetter, S., Williams, R.G., Roussenov, V., Reed, M.S.C., Moore, N.J., 2008. The Spatial Pattern and Mechanisms of Heat-Content Change in the North Atlantic. Science (80-. ). 319, 800-803. doi:10.1126/science.1146436

Lumpkin, R., Speer, K., 2007. Global Ocean Meridional Overturning. J. Phys. Oceanogr. 37, 2550-2562. doi:10.1175/JPO3130.1

Lutz, M.J., Caldeira, K., Dunbar, R.B., Behrenfeld, M.J., 2007. Seasonal rhythms of net primary production and particulate organic carbon flux to depth describe the efficiency of biological pump in the global ocean. J. Geophys. Res. Ocean. 112. doi:10.1029/2006JC003706

Macrander, A., Send, U., Valdimarsson, H., Jónsson, S., Käse, R.H., 2005. Interannual changes in the overflow from the Nordic Seas into the Atlantic Ocean through Denmark Strait. Geophys. Res. Lett. 32, 1-4. doi:10.1029/2004GL021463

Martin, J.H., Knauer, G.A., Karl, D.M., Broenkow, W.W., 1987. VERTEX: carbon cycling in the northeast Pacific. Deep Sea Res. Part A, Oceanogr. Res. Pap. 34, 267-285. doi:10.1016/0198-0149(87)90086-0

Maze, G., Mercier, H., Thierry, V., Memery, L., Morin, P., Perez, F.F., 2012. Mass, nutrient and oxygen budgets for the northeastern Atlantic Ocean. Biogeosciences 9, 4099-4113. doi:10.5194/bg-9-4099-2012

Mercier, H., 1986. Determining the general circulation of the ocean: A nonlinear inverse 
problem. J. Geophys. Res. Ocean. 91, 5103-5109. doi:10.1029/JC091iC04p05103

Mercier, H., Lherminier, P., Sarafanov, A., Gaillard, F., Daniault, N., Desbruyères, D., Falina, A., Ferron, B., Gourcuff, C., Huck, T., Thierry, V., 2015. Variability of the meridional overturning circulation at the Greenland-Portugal OVIDE section from 1993 to 2010. Prog. Oceanogr. 132, 250-261. doi:10.1016/j.pocean.2013.11.001

Millero, F.J., Lee, K., Roche, M., 1998. Distribution of alkalinity in the surface waters of the major oceans, in: Marine Chemistry. pp. 111-130. doi:10.1016/S0304-4203(97)00084-4

Najjar, G., Keeling, R.F., 2000. Mean annual cycle of the air-sea oxygen flux : A global view sat $\mathrm{C}$ at $\mathrm{J} \mathrm{kg}$ In ice-covered equal. Global Biogeochem. Cycles 14, 573-584. doi:08866236/00/1999GB 900086512.00

Nondal, G., Bellerby, R.G.J., Olsen, A., Johannessen, T., Olafsson, J., 2009. Optimal evaluation of the surface ocean $\mathrm{CO}_{2}$ system in the northern North Atlantic using data from voluntary observing ships. Limnol. Oceanogr. Methods 7, 109-118. doi:10.4319/lom.2009.7.109

Olsen, A., Key, R.M., Van Heuven, S., Lauvset, S.K., Velo, A., Lin, X., Schirnick, C., Kozyr, A., Tanhua, T., Hoppema, M., Jutterström, S., Steinfeldt, R., Jeansson, E., Ishii, M., Pérez, F.F., Suzuki, T., 2016. The global ocean data analysis project version 2 (GLODAPv2) - An internally consistent data product for the world ocean. Earth Syst. Sci. Data 8, 297-323. doi:10.5194/essd-8-297-2016

Østerhus, S., Turrell, W.R., Jónsson, S., Hansen, B., 2005. Measured volume, heat, and salt fluxes from the Atlantic to the Arctic Mediterranean. Geophys. Res. Lett. 32, 1-4. doi:10.1029/2004GL022188

Perez, F.F., Fontela, M., García-lbáñez, M.I., Mercier, H., Velo, A., Lherminier, P., Zunino, P., De La Paz, M., Alonso-Pérez, F., Guallart, E.F., Padin, X.A., 2018. Meridional overturning circulation conveys fast acidification to the deep Atlantic Ocean. Nature. doi:10.1038/nature25493

Pérez, F.F., Mercier, H., Vázquez-Rodríguez, M., Lherminier, P., Velo, A., Pardo, P.C., Rosón, G., Ríos, A.F., 2013. Atlantic Ocean CO2 uptake reduced by weakening of the meridional overturning circulation. Nat. Geosci. 6, 146-152. doi:10.1038/ngeo1680

Pérez, F.F., Vázquez-Rodríguez, M., Mercier, H., Velo, A., Lherminier, P., Ríos, A.F., 2010. Trends of anthropogenic CO2 storage in North Atlantic water masses. Biogeosciences 7, 1789-1807. doi:10.5194/bg-7-1789-2010

Piron, A., Thierry, V., Mercier, H., Caniaux, G., 2017. Gyre-scale deep convection in the subpolar North Atlantic Ocean during winter 2014-2015. Geophys. Res. Lett. 44, 14391447. doi:10.1002/2016GL071895

Poulton, A.J., Sanders, R., Holligan, P.M., Stinchcombe, M.C., Adey, T.R., Brown, L., Chamberlain, K., 2006. Phytoplankton mineralization in the tropical and subtropical Atlantic Ocean. Global Biogeochem. Cycles 20, 1-10. doi:10.1029/2006GB002712

Puigcorbé, V., Roca-Martí, M., Masqué, P., Benitez-Nelson, C., van der Loeff, M.R., Bracher, A., Moreau, S., 2017. Latitudinal distributions of particulate carbon export across the North Western Atlantic Ocean. Deep Sea Res. Part I Oceanogr. Res. Pap. 129, 116-130. doi:10.1016/j.dsr.2017.08.016 
Ragueneau, O., Dittert, N., Pondaven, P., Tr, P., Corrin, L., 2002. Si/C decoupling in the world ocean: is the Southern Ocean different ? Deep. Res. Part II Top. Stud. Oceanogr. 49, 3127-3154.

Redfield, A.C., 1934. On the proportions of organic derivatives in sea water and their relation to the composition of plankton, in: James Johnstone Memorial Volume. Liverpool Univ. Press, Liverpool, England, pp. 176-192.

Redfield, A.C., Ketchum, B.H., Richards, F.A., 1963. The influence of organisms on the composition of sea-water, in: The Sea: Ideas and Observations on Progress in the Study of the Seas.

Riley, J.S., Sanders, R., Marsay, C., Le Moigne, F.A.C., Achterberg, E.P., Poulton, A.J., 2012. The relative contribution of fast and slow sinking particles to ocean carbon export. Global Biogeochem. Cycles 26, 1-10. doi:10.1029/2011GB004085

Rödenbeck, C., Bakker, D.C.E., Gruber, N., lida, Y., Jacobson, A.R., Jones, S., Landsch??tzer, P., Metzl, N., Nakaoka, S., Olsen, A., Park, G.H., Peylin, P., Rodgers, K.B., Sasse, T.P., Schuster, U., Shutler, J.D., Valsala, V., Wanninkhof, R., Zeng, J., 2015. Data-based estimates of the ocean carbon sink variability - First results of the Surface Ocean pCO2 Mapping intercomparison (SOCOM). Biogeosciences 12, 7251-7278. doi:10.5194/bg-127251-2015

Roessler, A., Rhein, M., Kieke, D., Mertens, C., 2015. Long-term observations of North Atlantic Current transport at the gateway between western and eastern Atlantic. J. Geophys. Res. Ocean. 120, 4003-4027. doi:10.1002/2014JC010662

Sambrotto, R.N., Savidge, G., Robinson, C., Boyd, P., Takahashi, T., Karl, D.M., Langdon, C., Chipman, D., Marra, J., Codispoti, L., 1993. Elevated consumption of carbon relative to nitrogen in the surface ocean. Nature 363, 248-250. doi:10.1038/363248a0

Sanders, R., Henson, S.A., Koski, M., De La Rocha, C.L., Painter, S.C., Poulton, A.J., Riley, J., Salihoglu, B., Visser, A., Yool, A., Bellerby, R., Martin, A.P., 2014. The Biological Carbon Pump in the North Atlantic. Prog. Oceanogr. 129, 200-218. doi:10.1016/j.pocean.2014.05.005

Sarafanov, A., Falina, A., Mercier, H., Sokov, A., Lherminier, P., Gourcuff, C., Gladyshev, S., Gaillard, F., Daniault, N., 2012. Mean full-depth summer circulation and transports at the northern periphery of the Atlantic Ocean in the 2000s. J. Geophys. Res. Ocean. 117. doi:10.1029/2011JC007572

Sarmiento, J.L., Gruber, N., 2004. Ocean Biogeochemical Dynamics.

Sarmiento, J.L., Slater, R., Barber, R., Bopp, L., Doney, S.C., Hirst, A.C., Kleypas, J., Matear, R., Mikolajewicz, U., Monfray, P., Soldatov, V., Spall, S.A., Stouffer, R., 2004. Response of ocean ecosystems to climate warming. Global Biogeochem. Cycles. doi:10.1029/2003GB002134

Sharples, J., Middelburg, J.J., Fennel, K., Jickells, T.D., 2016. What proportion of riverine nutrients reaches the open ocean? Global Biogeochem. Cycles. doi:10.1002/2016GB005483

Steinfeldt, R., Rhein, M., Bullister, J.L., Tanhua, T., 2009. Inventory changes in anthropogenic 
carbon from $1997-2003$ in the Atlantic Ocean between $20^{\circ} \mathrm{S}$ and $65^{\circ} \mathrm{N}$. Global Biogeochem. Cycles 23, 1-11. doi:10.1029/2008GB003311

Takahashi, T., Broecker, W.S., Langer, S., 1985. Redfield ratio based on chemical data from isopycnal surfaces. J. Geophys. Res. 90, 6907. doi:10.1029/JC090iC04p06907

Takahashi, T., Sutherland, S.C., Wanninkhof, R., Sweeney, C., Feely, R. a., Chipman, D.W., Hales, B., Friederich, G., Chavez, F., Sabine, C., Watson, A., Bakker, D.C.E., Schuster, U., Metzl, N., Yoshikawa-Inoue, H., Ishii, M., Midorikawa, T., Nojiri, Y., Körtzinger, A.,

Steinhoff, T., Hoppema, M., Olafsson, J., Arnarson, T.S., Tilbrook, B., Johannessen, T., Olsen, A., Bellerby, R., Wong, C.S., Delille, B., Bates, N.R., de Baar, H.J.W., 2009.

Climatological mean and decadal change in surface ocean pCO2, and net sea-air $\mathrm{CO} 2$ flux over the global oceans. Deep. Res. Part II Top. Stud. Oceanogr. 56, 554-577. doi:10.1016/j.dsr2.2008.12.009

Tanhua, T., Keeling, R.F., 2012. Changes in column inventories of carbon and oxygen in the Atlantic Ocean. Biogeosciences 9, 4819-4833. doi:10.5194/bg-9-4819-2012

Torres-Valdés, S., Tsubouchi, T., Bacon, S., Naveira-Garabato, A.C., Sanders, R., McLaughlin, F.A., Petrie, B., Kattner, G., Azetsu-Scott, K., Whitledge, T.E., 2013. Export of nutrients from the Arctic Ocean. J. Geophys. Res. Ocean. 118, 1625-1644. doi:10.1002/jgrc.20063

Villa-Alfageme, M., De Soto, F., Le Moigne, F.A.C., Giering, S.L.C., Sanders, R., GarcíaTenorio, R., 2014. Observations and modeling of slow-sinking particles in the twilight zone. Global Biogeochem. Cycles 28, 1327-1342. doi:10.1002/2014GB004981

Villa-Alfageme, M., de Soto, F.C., Ceballos, E., Giering, S.L.C., Le Moigne, F.A.C., Henson, S., Mas, J.L., Sanders, R.J., 2016. Geographical, seasonal, and depth variation in sinking particle speeds in the North Atlantic. Geophys. Res. Lett. 43, 8609-8616. doi:10.1002/2016GL069233

Volk, T., Hoffert, M.I., 1985. Ocean carbon pumps: Analysis of relative strength and efficiencies in ocean-driven atmospheric $\mathrm{CO}_{2}$ changes. Geophys. Monogr. Ser. 32, 99-110. doi:10.1029/GM032p0099

Waniek, J.J., Holliday, N.P., Davidson, R., Brown, L., Henson, S.A., 2005. Freshwater control of onset and species composition of Greenland shelf spring bloom. Mar. Ecol. Prog. Ser. 288, 45-57. doi:10.3354/meps288045

Willis, J.K., 2010. Can in situ floats and satellite altimeters detect long-term changes in Atlantic Ocean overturning? Geophys. Res. Lett. 37, n/a-n/a. doi:10.1029/2010GL042372

Wolf-Gladrow, D.A., Zeebe, R.E., Klaas, C., Körtzinger, A., Dickson, A.G., 2007. Total alkalinity: The explicit conservative expression and its application to biogeochemical processes. Mar. Chem. 106, 287-300. doi:10.1016/j.marchem.2007.01.006

Yang, S., Gruber, N., 2016. The anthropogenic perturbation of the marine nitrogen cycle by atmospheric deposition. Glob. Biogeochem. Cycles 1418-1440. doi:10.1002/2016GB005421.Received

Zunino, P., Lherminier, P., Mercier, H., Daniault, N., Isabel, M., 2017. The GEOVIDE cruise in May-June 2014 reveals an intense Meridional Overturning Circulation over a cold and fresh subpolar North Atlantic. 
Zunino, P., Lherminier, P., Mercier, H., Padín, X.A., Ríos, A.F., Pérez, F.F., 2015. Dissolved inorganic carbon budgets in the eastern subpolar North Atlantic in the 2000s from in situ data 1-9. doi:10.1002/2015GL066243.Received 


\title{
Long-term integrated biogeochemical budget driven by circulation in the eastern subpolar North Atlantic
}

\author{
Marcos Fontela ${ }^{1}$, Herlé Mercier ${ }^{2}$, Fiz F. Pérez ${ }^{1}$
}

${ }^{1}$ Instituto de Investigaciones Marinas, IIM-CSIC, 36208 Vigo, Spain.

${ }^{2}$ CNRS, Laboratoire d'Océanographie Physique et Spatiale, UMR 6523 CNRSIFREMER-IRD-University of Brest, Plouzané, France.

\section{Appendix A. Supplementary text}

\section{A1. Additional inputs to the eSPNA}

We are going to discuss the suitability of the sources of info selected for the additional inputs.

\section{A1.1. Air-sea $\mathrm{CO}_{2}$ fluxes}

Air-sea $\mathrm{CO}_{2}$ fluxes are computed as the difference in real measurements of the atmospheric and oceanic partial pressures of $\mathrm{CO}_{2}\left(\mathrm{pCO}_{2}\right)$ multiplied by the $\mathrm{CO}_{2}$ gas transfer coefficient (Takahashi et al., 2009). Despite the growing database of SOCATv2, with more than 10 million surface ocean $\mathrm{pCO}_{2}$ measurements (Bakker et al., 2016), the dataset is still sparse in time and space. To obtain continuous air-sea $\mathrm{CO}_{2}$ flux fields, interpolation methods are needed to estimate values in all periods and areas not directly observed (Rödenbeck et al., 2015). The Surface Ocean $\mathrm{pCO}_{2}$ Mapping intercomparison initiative (SOCOM) published in the year 2015 an intercomparison dataset based on fourteen different mapping methods at global scale. The methods span a wide range of approaches: statistical interpolation( Rödenbeck et al., 2014; Jones et al., 2015; Shutler et al., 2016; Jacobson et al., unpublished), model-based regression ( Valsala and Maksyutov, 2010; Majkut et al., 2014), multilinear regression (Park et al., 2010; Schuster et al., 2013; lida et al., 2015) and non-linear regression (Landschützer et al., 2013; Nakaoka et al., 2013; Sasse et al., 2013; Zeng et al., 2014).

The SOCOM initiative, in order to make its results comparable, used the time-independent "mean biomes" of (Fay and Mckinley, 2014). The utilization of biomes allows the partition of the surface ocean into large regions with biogeochemical similarities, rather than artificial geographical criteria (Fay \& McKinley, 2014). Global ocean biomes were downloaded from https://doi.pangaea.de/10.1594/PANGAEA.828650 [last time accessed: 28/06/2017]. Our region belongs mostly to the biome "North Atlantic Subpolar Seasonally Stratified" (NASPSS), with an area being "North Atlantic Subtropical Seasonally Stratified" (NASTSS) and a very little region close to Greenland as "North Atlantic Ice" (NAICE) (Fig. 1). In the eSPNA, the biome NASPSS represents $72 \%$ of the area, occupying almost all the Irminger Sea and the Iceland Basin (Fig. 
1). The environmental criteria that characterize the biomes and the area extension is shown in Table S1.

Table S1. Biome definition following (Fay \& McKinley, 2014) and the extension (in $\mathrm{km}^{2}$ ) that each biome represents in the eSPNA. NASPSS: North Atlantic Subpolar Seasonally Stratified, NASTSS: North Atlantic

Subtropical Seasonally Stratified, NAICE: North Atlantic Ice, SST: sea surface temperature, Chl a:

\begin{tabular}{|c|c|c|c|c|c|}
\hline Biome & $\begin{array}{c}\text { Area in } \\
\text { eSPNA } \\
\left(10^{6} \mathrm{~km}^{2}\right)\end{array}$ & $\begin{array}{c}\text { Area Mean } \\
\text { Biome } \\
\left(10^{6} \mathrm{~km}^{2}\right)\end{array}$ & $\begin{array}{l}\text { SST } \\
\left({ }^{\circ} \mathrm{C}\right)\end{array}$ & $\begin{array}{c}\mathrm{Chl} \mathrm{a} \\
\left(\mathrm{mg} \mathrm{m}^{-3}\right)\end{array}$ & Notes \\
\hline NASPSS & 2.7124 & 10.062 & $\mathrm{~T}^{\mathrm{a}}<14$ & $C h l a \geq 0.4$ & \\
\hline NASTSS & 0.9598 & 5.9744 & $11 \leq \mathrm{T}^{\mathrm{a}}<29$ & $0.16 \leq C h l a<0.4$ & Latitude $\geq 25^{\circ} \mathrm{N}$ \\
\hline NAICE & 0.0966 & 5.4750 & & & ce fraction $>0.5$ \\
\hline
\end{tabular}

The time-series for the period 1992-2009 for each one of the methods and the mean biomes can be downloaded from the SOCOM webpage (http://www.bgc-jena.mpg.de/SOCOM/) [last time accessed: 28/06/2017]. There is no data available for NAICE biome in SOCOM intercomparison dataset. The area contribution of NAICE to our study region, $\sim 2.5 \%$ of the total eSPNA, was thus considered as being NASPSS. This resulted in an increase in the uptake of only $5-7.5 \mathrm{kmol} \cdot \mathrm{s}^{-1}$.

The biome-mean air-sea $\mathrm{CO}_{2}$ flux at each time $\left(\operatorname{SOCOM}_{\text {biome }}^{\text {fluxf }}\right)$ is then multiplied by the relative contribution of that biome inside eSPNA with respect to the total biome mean area (Eq. S1):

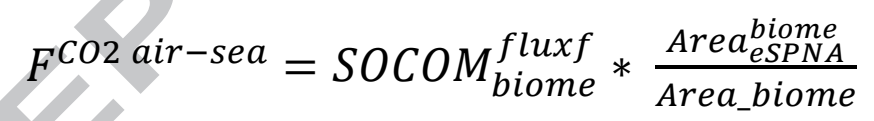

The yearly mean air-sea $\mathrm{CO}_{2}$ flux estimated for the 1986-2012 period is show in Fig. S1. The $F^{C O 2}$ air-sea $u s e d$ in the study for each one of the boxes comes from the mean uptake flux of 2002-2012 referred to year 2009 using an annual rate of increase of 1.69\% (Steinfeldt et al., 2009) and its standard error. The uptake is $274 \pm 13.8 \mathrm{kmol} \cdot \mathrm{s}^{-1}$ for the eSPNA distributed as $56 \pm 3$ $\mathrm{kmol} \cdot \mathrm{s}^{-1}$ in the Irminger and $218 \pm 11.3 \mathrm{kmol} \cdot \mathrm{s}^{-1}$ in the ENA. 


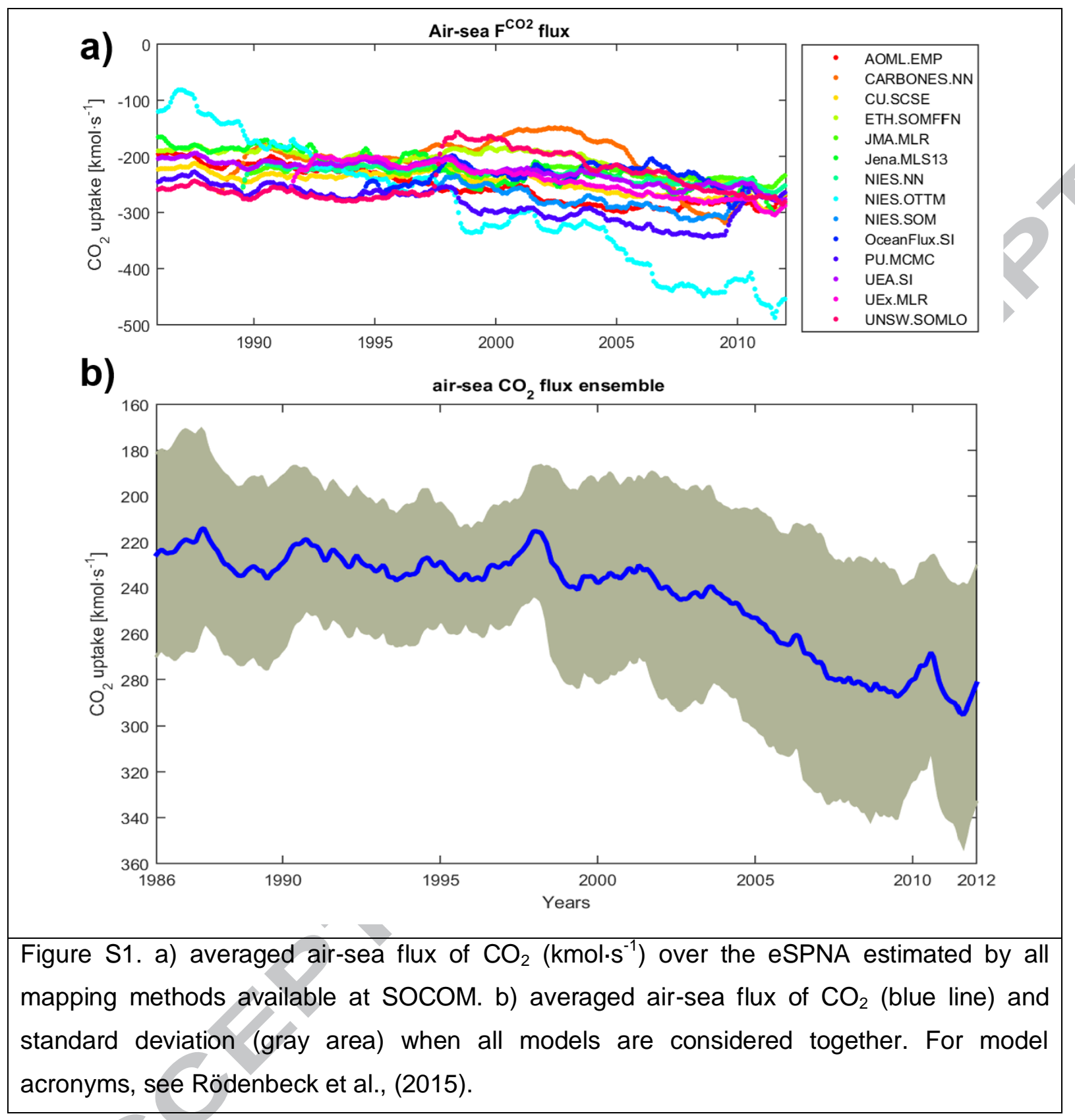

\section{A1.2 Additional inputs of nitrate}

External inputs of nitrogen can increase productivity (Jickells et al., 2017), and hence affect the budget. For the eSPNA, the total external input is $7.9 \pm 5.7 \mathrm{kmol} \cdot \mathrm{s}^{-1}$. Biological nitrogen fixation (BNF), the main external source of nitrogen to the open ocean, is taken from the biogeochemical model PlankTOM (Fig. 2 in Jickells et al., 2017). The PlankTOM model shows a global ocean BNF of $164 \mathrm{Tg} \mathrm{Nyr}^{-1}$ (Jickells et al., 2017), in agreement with other global 
estimates (Codispoti et al., 2001; Galloway et al., 2004; Gruber, 2008). The most representative of marine $\mathrm{N}_{2}$ fixers, Trichodesmium cyanobacteria, can be found at North Atlantic high latitudes (Rivero-Calle et al., 2016). However, it is believed that Trichodesmium has been advected from waters further south rather than being resident at these higher latitudes (Luo et al., 2012, 2014). Nevertheless, there are other groups of $\mathrm{N}_{2}$-fixing microorganisms (diazotrophs), as the diatomdiazotroph symbiosis or the non-cyanobacterial diazotrophs (Zehr and Kudela, 2011) that have been detected in the ENA (Moreira-Coello et al., 2017). The atmospheric nitrate deposition (AND) magnitude includes the increase in the anthropogenic perturbation since preindustrial times (Fig. 2c in Yang and Gruber, 2016).

\section{A1.3 Additional inputs from freshwater sources}

The decision to include external inputs of river origin for all the tracers is sustained by the projected increase in freshwater discharge at high latitudes with global warming (Peterson et al., 2002), and for the high proportions of riverine nutrients that could reach the open ocean unmodified by shelf biogeochemistry (Sharples et al., 2016). Furthermore, the influence of Greenland ice sheet melting in biogeochemical cycles is higher than previously considered (Hawkings et al., 2016, 2017).

DIC and alkalinity input from freshwater supply is calculated from their concentration in freshwater, the freshwater flux, and an assumed density of $1 \mathrm{~kg} \cdot \mathrm{m}^{-3}$. For the alkalinity concentration in freshwater, we used the regression relationship between alkalinity and sea surface salinity proposed for the northern North Atlantic (Eq. 6 in Nondal et al., 2009). DIC concentration in freshwater is the same as alkalinity, as done in the Nordic Seas carbon budget of Jeansson et al. (2011).

\section{A.2. Stoichiometric ratios: Si:C parameterization}

The Si:C ratio increases with depth due to slower remineralization of Si compared to $\mathrm{C}$ (Nelson et al., 1995; Ragueneau et al., 2002). A global ocean parameterization based on production, export, vertical transport and sedimentation of biogenic silica and organic carbon establishes a general equation (Eq. S2) to model the downward increase in Si:C ratios (Ragueneau et al., 2002):

$$
(\text { Si: } C)_{z}=(S i: C)_{0} * z^{0.41}(\text { Eq. S2), }
$$


where the $\mathrm{Si}: \mathrm{C}$ flux ratio at depth $\mathrm{z}\left((\mathrm{Si}: C)_{z}\right)$ is estimated with the Si:C flux ratio during production in surface waters $(S i: C)_{0}$, and the real bottom depth $(\mathrm{z})$. For the organic carbon flux attenuation with depth there is a similar power function with an exponent of 0.86 (Martin et al., 1987). To represent the processes occurring all over the water column, the stoichiometric ratio used inside the model ( $\left.r_{S i: C}\right)$ is the ratio of the depth-derivative of both equations,

$$
\frac{\partial S i}{\partial C}=r_{S i: C}=(S i: C)_{0} *\left(1-\frac{0.41}{0.86}\right) * z^{0.41} \text { (Eq. S3), }
$$

To estimate the vertical mean ratio needed for the full-depth biogeochemical budget, the downward increase in Si:C ratios has been estimated at each geographical point within at 6'x 6' resolution using gridded bathymetric data of the General Bathymetric Chart of the Oceans (GEBCO) 2014. The $(\mathrm{Si}: \mathrm{C})_{0}$ value in our area of study is 0.02 , among the lowest values found in the global ocean (Pondaven et al., 1999). In the North Atlantic, the low silicate concentrations in the upper ocean limits the contribution of diatoms to total production (Brzezinski and Nelson, 1996) and the production of diatoms that are not heavily silicified is a normal feature (Nelson and Brzezinski, 1997). The mean values for the Si:C ratio are $0.20,0.18,0.21$ for the whole eSPNA, the Irminger and the ENA, respectively.

\section{A.4. Robustness assessment}

In this section we address the strengths and limitations of our model solution. First of all, the oceanic transports and divergences can be considerably improved through the averaging of repeated sections (Ganachaud and Wunsch, 2002). Here we show total transports supported by eight repetitions of OVIDE section, a number quite considerable for a basin-scale section. Furthermore, several criteria were required for the output of the model to be considered acceptable: We required a decrease in the residuals of the constraints after inversion; we required that results keep consistence when a section is removed; and also we required independent results with regard of the initial box-model configuration. Sensitivity analysis were also done modifying the stoichiometric ratios or the a priori values and/or its range of errors. In order to evaluate the robustness of our results, a set of tests have been performed:

\section{A.4.1. Residuals of the constraints after inversion}

If the mathematical optimization works, we expect a decrease in the residuals of the constraints after inversion with respect to the initial guess. In order to visualize the optimization provided by the inverse model in the final resolution, and taking into account that the residuals in the equations between different tracers have different orders of magnitude, in Fig.S2 the residuals 
are normalized, i.e., the residual of each equation has been divided by the error of the constraint equation (Table 3 of main text).

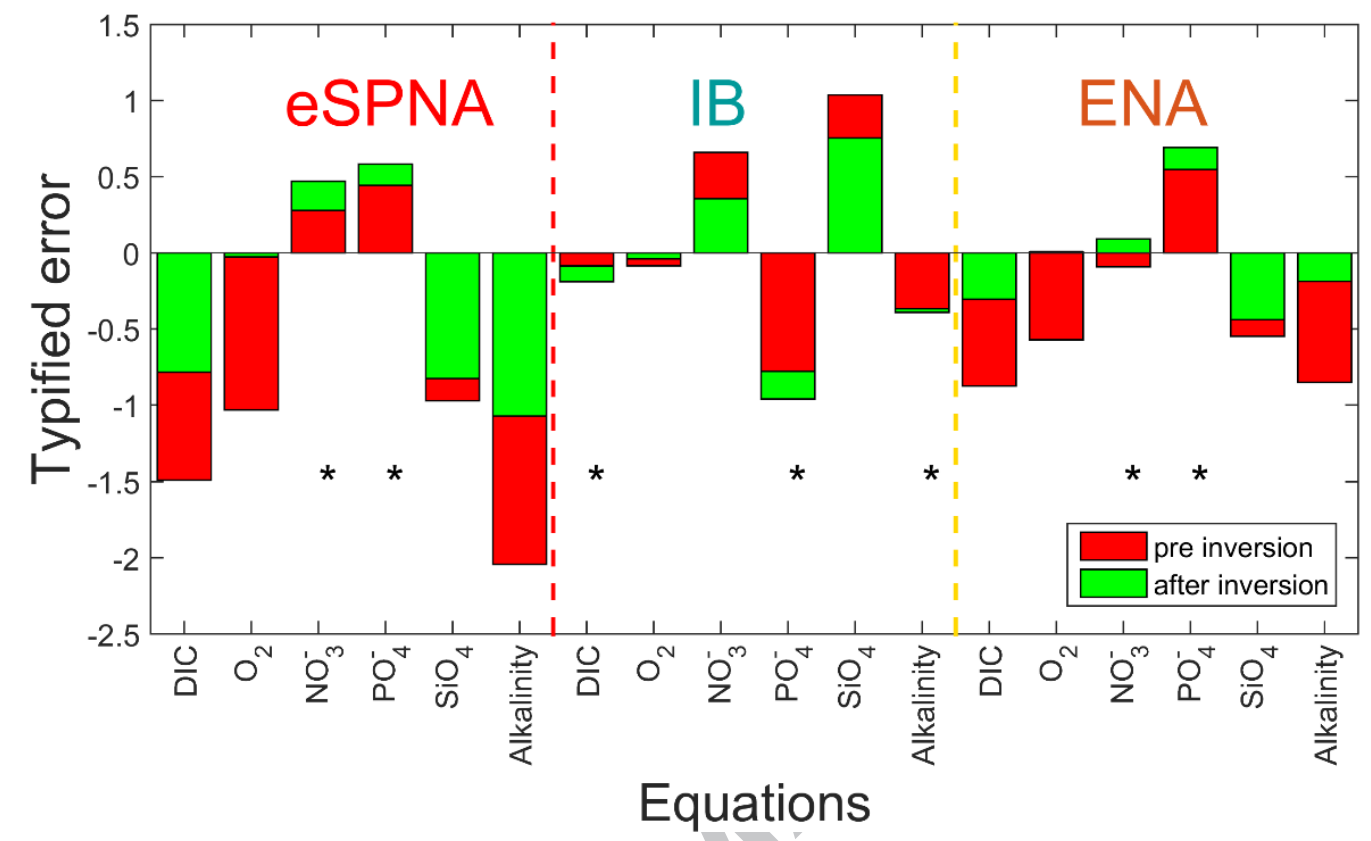

Figure S2. Bar plot representation of the normalized residuals of the constraint equations pre-inversion (red bar) and after inversion (green bar) for the biogeochemical equations. Note that when the green bar is not visible is because it is very close to zero. X-label inform of the tracer equation. The red (yellow) dash line separates IB from eSPNA (ENA). Denoted with * are the equations whose residuals after inversion are not lower than the pre-inversion residuals.

As can be seen in Fig. S2, the improvement in the residuals is a generalized feature of the model, the normalized residuals are usually greater before inversion than the normalized residuals after-inversion. This means that the final output enhances the knowledge of the system without compromise its internal consistency. The inverse model gives us an output that is the best estimate among the information possibilities.

\section{A.4.2. Errors on the unknowns after inversion}

If the mathematical optimization works, the error of the unknowns after inversion should be lower than the a priori errors. After the inversion, error bars for the unknowns are always lower than before (Fig. S3). 

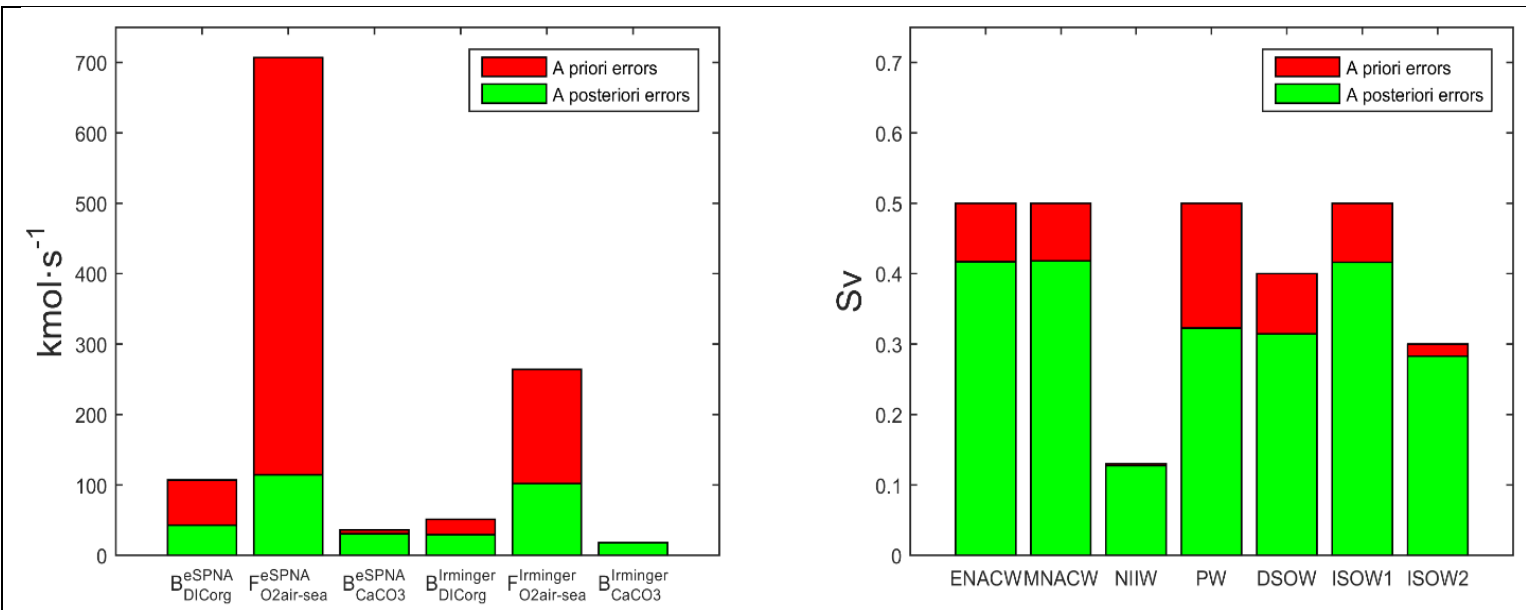

Figure S3. Bar plot representation of the error of the unknowns a priori (red bar) and after inversion (green bar) for the biogeochemical unknowns (left) and for the water masses at the G-I-S sills (right).

\section{A.4.3. Box-model configuration}

In a three box-model configuration, the linear relationship between the boxes allows to determine the unknowns in three regions resolving only two regions (Equation 19 main text). The hypothesis tested in this point is that with independence of the selected boxes to solve the model, the results would be similar. If in the main text we give the output for the combination of whole eSPNA plus Irminger Basin (Table 2, main text), the following alternative outputs explore the other box-model configurations: resolving the whole eSPNA and the ENA or resolving the Irminger plus the ENA. The results are given in the Table S2.

Table S2. Inverse box-model solution for all the possible box-model configurations. The column "eSPNA \& IB" is the configuration developed in the main text, that solves the ENA outside the model; "eSPNA \& ENA" is the configuration that solves the Irminger outside the model; and "IB \& ENA" solves the whole eSPNA outside the model, as the sum of its parts.

\begin{tabular}{|c|l|r|r|r|}
\cline { 3 - 5 } \multicolumn{2}{c|}{} & eSPNA \& IB & eSPNA \& ENA & IB \& ENA \\
\hline \multirow{2}{*}{$\begin{array}{c}\mathrm{B}_{\mathrm{DIC}} \\
\left(\mathrm{kmolg} \cdot \mathrm{or}^{-1}\right)\end{array}$} & eSPNA & $119 \pm 43$ & $108 \pm 42$ & $105 \pm 45$ \\
\cline { 2 - 5 } & Irminger & $34 \pm 29$ & $36 \pm 50$ & $27 \pm 34$ \\
\cline { 2 - 5 } & ENA & $85 \pm 52$ & $82 \pm 28$ & $78 \pm 27$ \\
\hline $\mathrm{B}_{\mathrm{CaCO}_{3}}$ & eSPNA & $49 \pm 31$ & $60 \pm 28$ & $39 \pm 24$ \\
\hline
\end{tabular}




\begin{tabular}{|c|c|c|c|c|}
\hline \multirow[t]{2}{*}{$\left(\mathrm{kmol} \cdot \mathrm{s}^{-1}\right)$} & Irminger & $9 \pm 18$ & $10 \pm 33$ & $9 \pm 17$ \\
\hline & ENA & $40 \pm 35$ & $50 \pm 18$ & $30 \pm 17$ \\
\hline \multirow{3}{*}{$\begin{array}{l}\mathrm{F}^{\mathrm{O} 2 \text { air-sea }} \\
\left(\mathrm{kmol} \cdot \mathrm{s}^{-1}\right)\end{array}$} & eSPNA & $807 \pm 114$ & $822 \pm 83$ & $826 \pm 85$ \\
\hline & Irminger & $292 \pm 102$ & $321 \pm 132$ & $307 \pm 45$ \\
\hline & ENA & $516 \pm 153$ & $501 \pm 103$ & $519 \pm 72$ \\
\hline \multirow{7}{*}{$\begin{array}{l}\text { Volume } \\
\text { Transport } \\
\text { (Sv) }\end{array}$} & $\mathrm{SV}_{\text {ENACW }}{ }^{\text {Sills }}$ & $3.93 \pm 0.42$ & $3.95 \pm 0.41$ & $3.96 \pm 0.41$ \\
\hline & SV $_{\text {MNACW }}^{\text {Sills }}$ & $3.90 \pm 0.42$ & $3.91 \pm 0.42$ & $3.92 \pm 0.42$ \\
\hline & $\mathrm{SV}_{\text {ISOW1 }}{ }^{\text {Sills }}$ & $-1.00 \pm 0.42$ & $-1.04 \pm 0.41$ & $-1.05 \pm 0.41$ \\
\hline & $\mathrm{SV}_{\text {ISOW2 }}{ }^{\text {Sills }}$ & $-2.00 \pm 0.28$ & $-2.01 \pm 0.28$ & $-2.02 \pm 0.28$ \\
\hline & $\mathrm{SV}_{\text {NIII }}$ Sills & $0.88 \pm 0.13$ & $0.89 \pm 0.13$ & $0.88 \pm 0.13$ \\
\hline & $\mathrm{SV}_{\mathrm{PW}}{ }^{\text {Sills }}$ & $-1.84 \pm 0.32$ & $-1.82 \pm 0.32$ & $-1.79 \pm 0.32$ \\
\hline & $\mathrm{SV}_{\text {Dsow }}{ }^{\text {Sills }}$ & $-2.97 \pm 0.31$ & $-2.97 \pm 0.31$ & $-2.99 \pm 0.31$ \\
\hline
\end{tabular}

As expected, there is variability in the outputs with the change of the information used to constraint, but it is always inside the range of uncertainties. The error for the unknown solved outside the model is estimated with an error propagation technique. This is the reason why the unknown solution of the biogeochemical tracer not solved by the model shows always the greater error. The consistency of the water mass fluxes at the G-I-S sills give us confidence in that the selection of one box-model configuration or another does not have a substantial impact in the biogeochemical budgets.

\section{A.4.4. Seasonal and interannual variability}

Our approach has some limits as the influence of the seasonal variability. With regard to the transports, the MOC circulation at the time of OVIDE section (June-July) is close to the mean circulation state (Mercier et al., 2015). With regard to changes in tracer concentration due to seasonality, they should affect both lateral boundaries (OVIDE section and G-I-S sills) in the same way. Then, seasonal variability can be neglected in the surface layer without generating any important seasonal bias in the tracer transport divergence. Changes in nutrient concentration due to variability in the timing of primary production can also have an influence. When winter conditions are simulated (with a constant "deep" concentration of nutrients between 0-100 dbar), the conclusion of net autotrophy for the eSPNA persists ( $B_{\text {DICorg }}=137 \pm 43$ $\mathrm{kmol} \cdot \mathrm{s}^{-1}, \mathrm{~F}_{2}$ air-sea $=781 \pm 114 \mathrm{kmol} \cdot \mathrm{s}^{-1}$ and $\mathrm{B}_{\mathrm{CaCO}_{3}}=49 \pm 31$ ) with an output that is within the range of uncertainties of our reference solution. Seasonal variability does not affect the storage rate term because all cruises were made at the same season. 
Interannual variability is represented by the large variation observed in the tracer transport at the OVIDE section. If the model is affect by interannual variability of one of the cruises, the change associated with the inclusion/not inclusion of a specific cruise would alter the final result. In order to evaluate the robustness of our results, Figure S4 shows the unknowns optimized by the model with respect to the cruise selection.
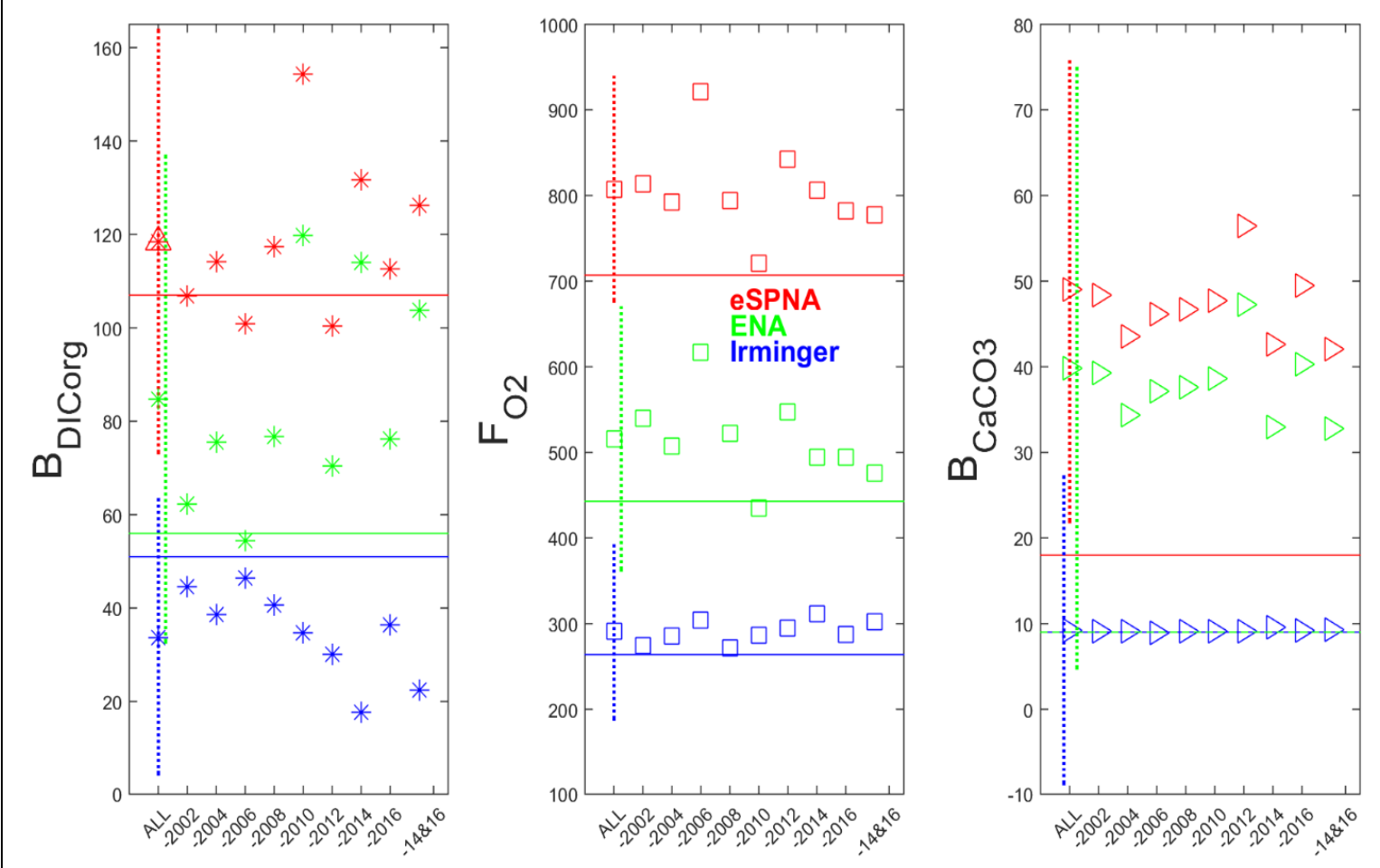

Figure S4. Interannual variability assessment. Values for the unknowns after inversion in $\mathrm{kmol} \cdot \mathrm{s}^{-1}$ when a cruise is excluded (eSPNA in red, IB in blue, and ENA in green). The estimates that include all repetitions of OVIDE is the first point in the $x$-axis ("ALL"). The model was re-ran excluding a given cruise: situation "-2002" does not include the 2002 cruise, "-2004" does not include the 2004 cruise, ... "-14\&16" does not include the 2014 and 2016 cruises. Horizontal color lines represent the a priori values. Vertical color dashed lines are the error bars of the "ALL" situation.

There is some variability showing that the model is sensitive to a change in the data set. However, even the extreme values are usually inside the range of the uncertainties with respect to the "ALL" solution (solutions are inside the dashed error bars of the "ALL" solution: $\sim \pm 35$ $\mathrm{kmol} \cdot \mathrm{s}^{-1}$ for $\mathrm{B}_{\mathrm{DICorg}}, \sim \pm 100 \mathrm{kmol} \cdot \mathrm{s}^{-1}$ for $\mathrm{F}^{\mathrm{O}_{2}}$ air-sea and $\sim \pm 10 \mathrm{kmol} \cdot \mathrm{s}^{-1}$ for $\mathrm{B}_{\mathrm{CaCO}_{3}}$. 
Recently, a cooling trend in the North Atlantic has been reported (Robson et al., 2016), sharply affected by the short-term cooling event of years 2013-2014 (Zunino et al., 2017). The no inclusion of both 2014 and 2016 cruises allows testing sensitivity to the potential effect of a cold eSPNA. As can be seen in Fig. S4, the outputs are not anomalous. Excluding the two cruises alters the estimates of the biological parameters but within error bars of the "ALL" solution. There is no evidence of a change in the biogeochemical status with respect to a colder status of the eSPNA.

\section{Appendix B. Supplementary material}

Supplementary data associated with this article can be found, in the online version, at:

\section{B.1. Vertical tracer distribution along OVIDE section 2002-2016}

\section{DIC}
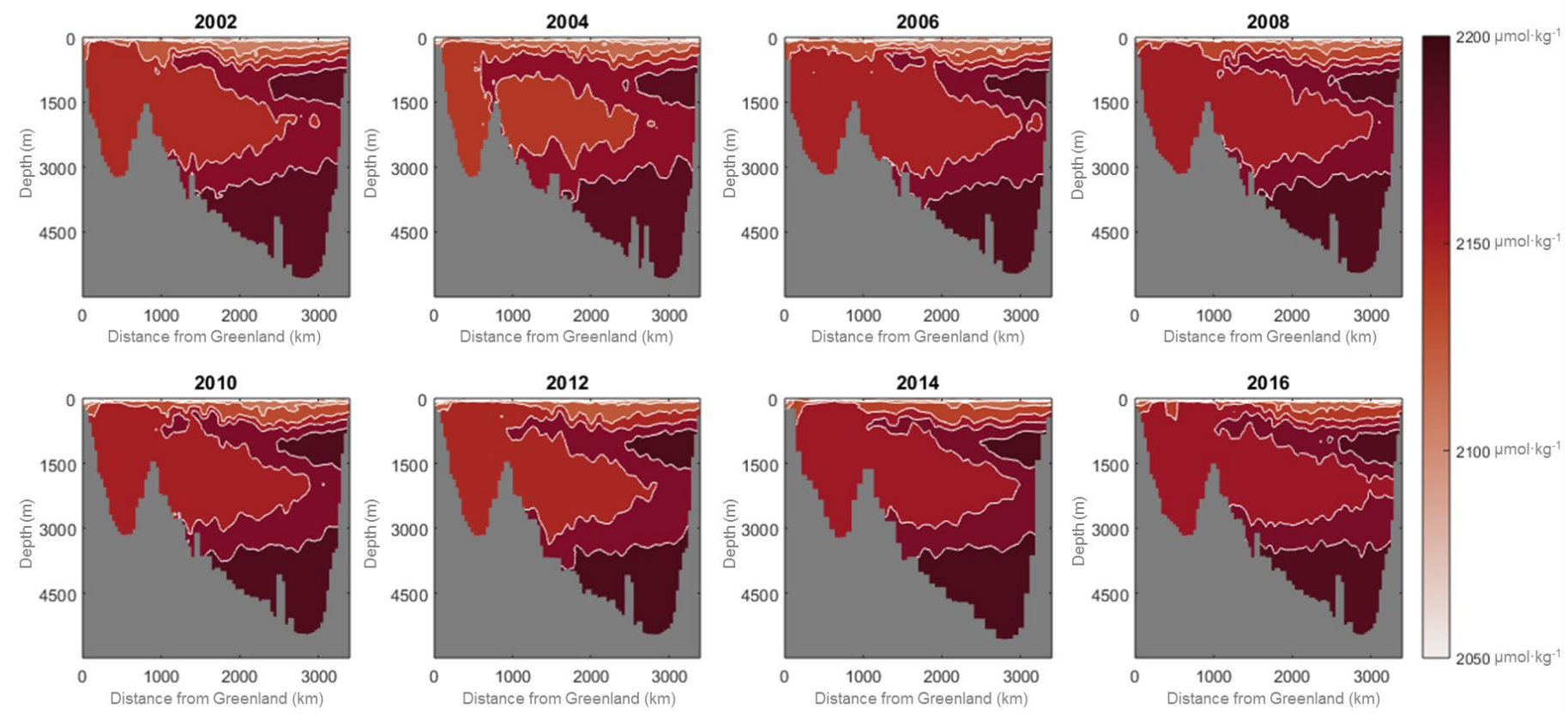

Figure S5. Dissolved inorganic carbon (DIC, in $\mu \mathrm{mol} \cdot \mathrm{kg}^{-1}$ ) vertical distribution along the OVIDE section from Greenland (left) to the Iberian Peninsula (right). Represented is the density interpolated bottle data from each one of the eight repetitions of the OVIDE section, from 2002 to 2016. 

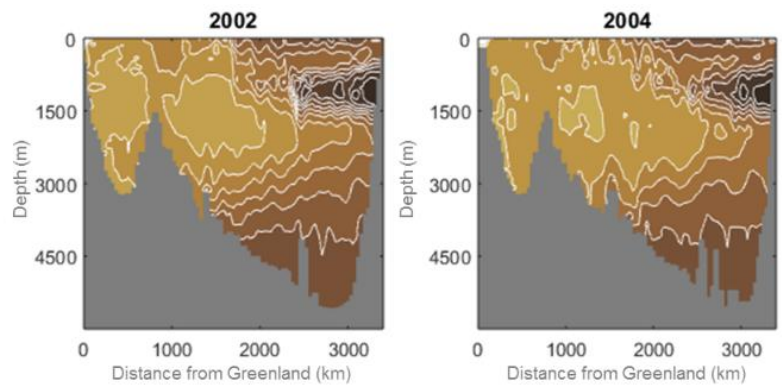

Alkalinity
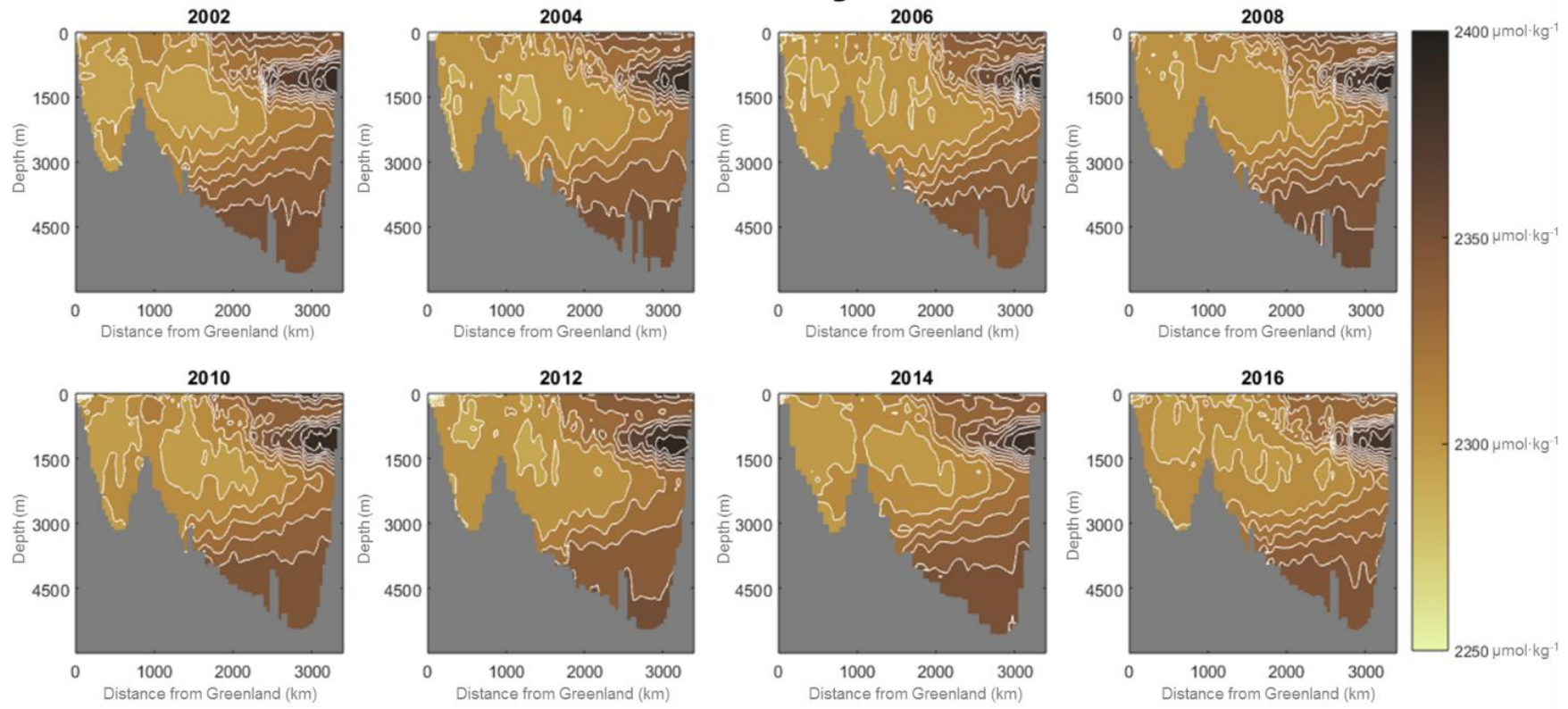

Figure S6. Total alkalinity ( $\mu \mathrm{mol} \cdot \mathrm{kg}^{-1}$ ) vertical distribution along the OVIDE section from Greenland (left) to the Iberian Peninsula (right). Represented is the density interpolated bottle data from each one of the eight repetitions of the OVIDE section, from 2002 to 2016.
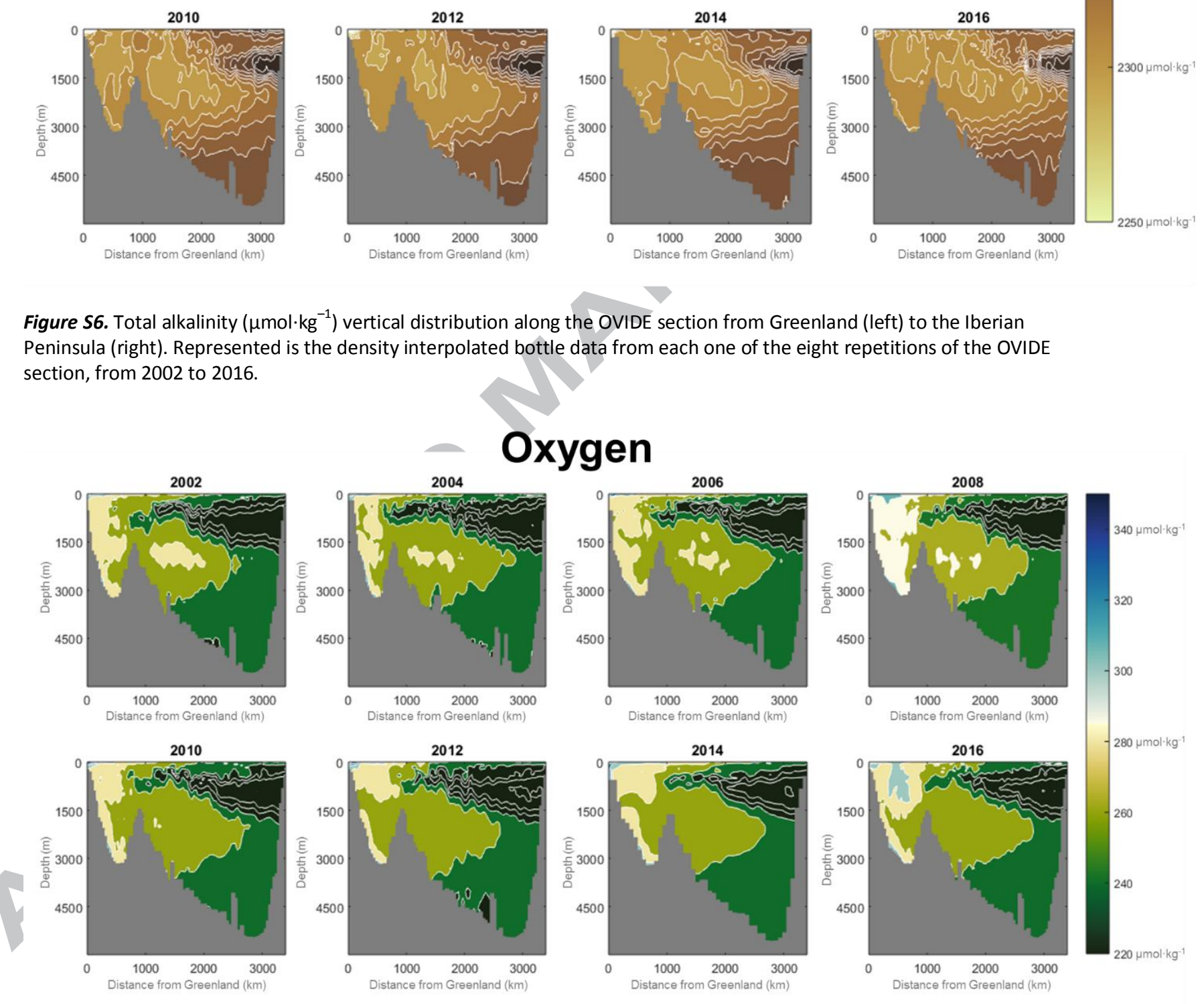

Figure S7. Dissolved oxygen $\left(\mu \mathrm{mol} \cdot \mathrm{kg}^{-1}\right)$ vertical distribution along the OVIDE section from Greenland (left) to the lberian Peninsula (right). Represented is the density interpolated bottle data from each one of the eight repetitions of the OVIDE section, from 2002 to 2016. 

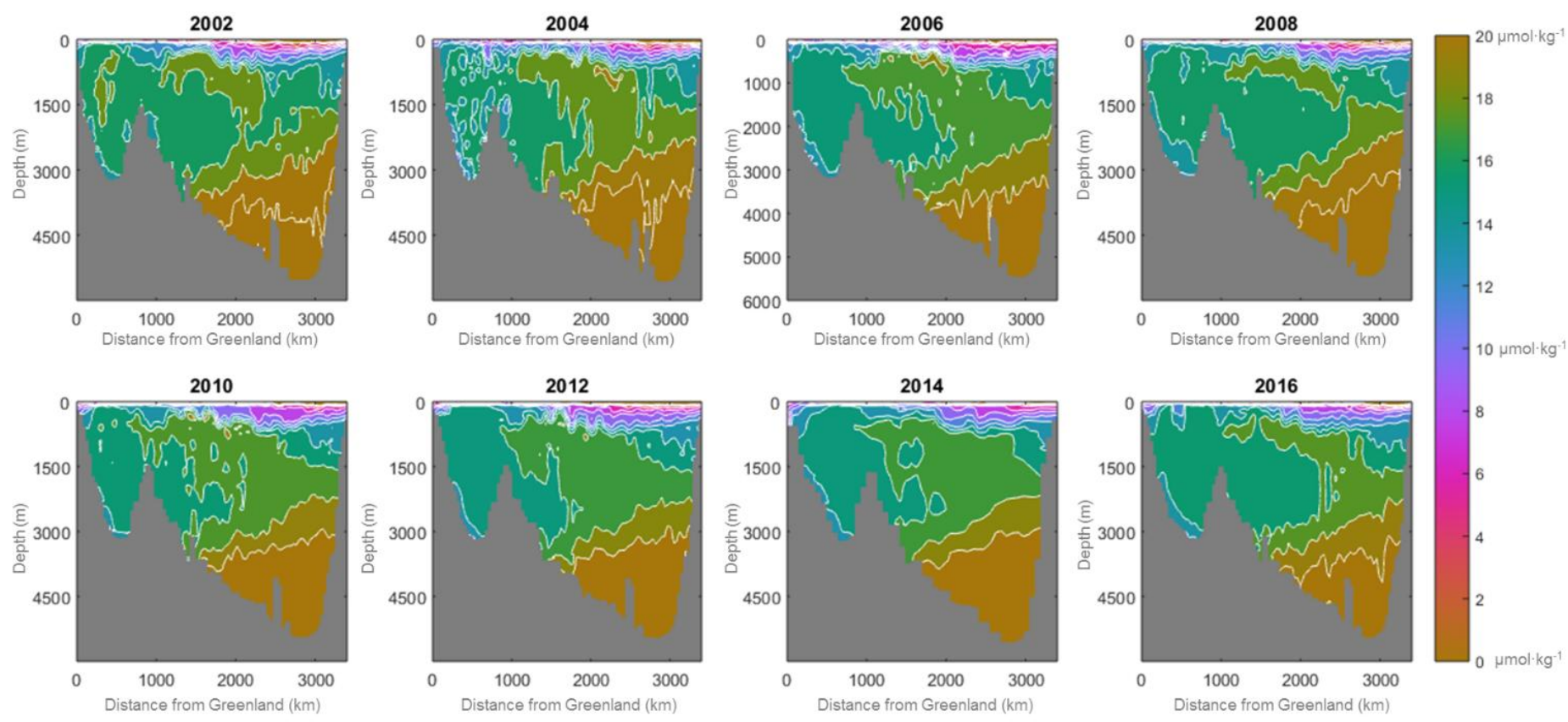

Figure S8. Nitrate $\left(\mathrm{NO}_{3}{ }^{-}\right.$, in $\left.\mu \mathrm{mol} \cdot \mathrm{kg}^{-1}\right)$ vertical distribution along the OVIDE section from Greenland (left) to the Iberian Peninsula (right). Represented is the density interpolated bottle data from each one of the eight repetitions of the OVIDE section, from 2002 to 2016.

\section{Phosphate}
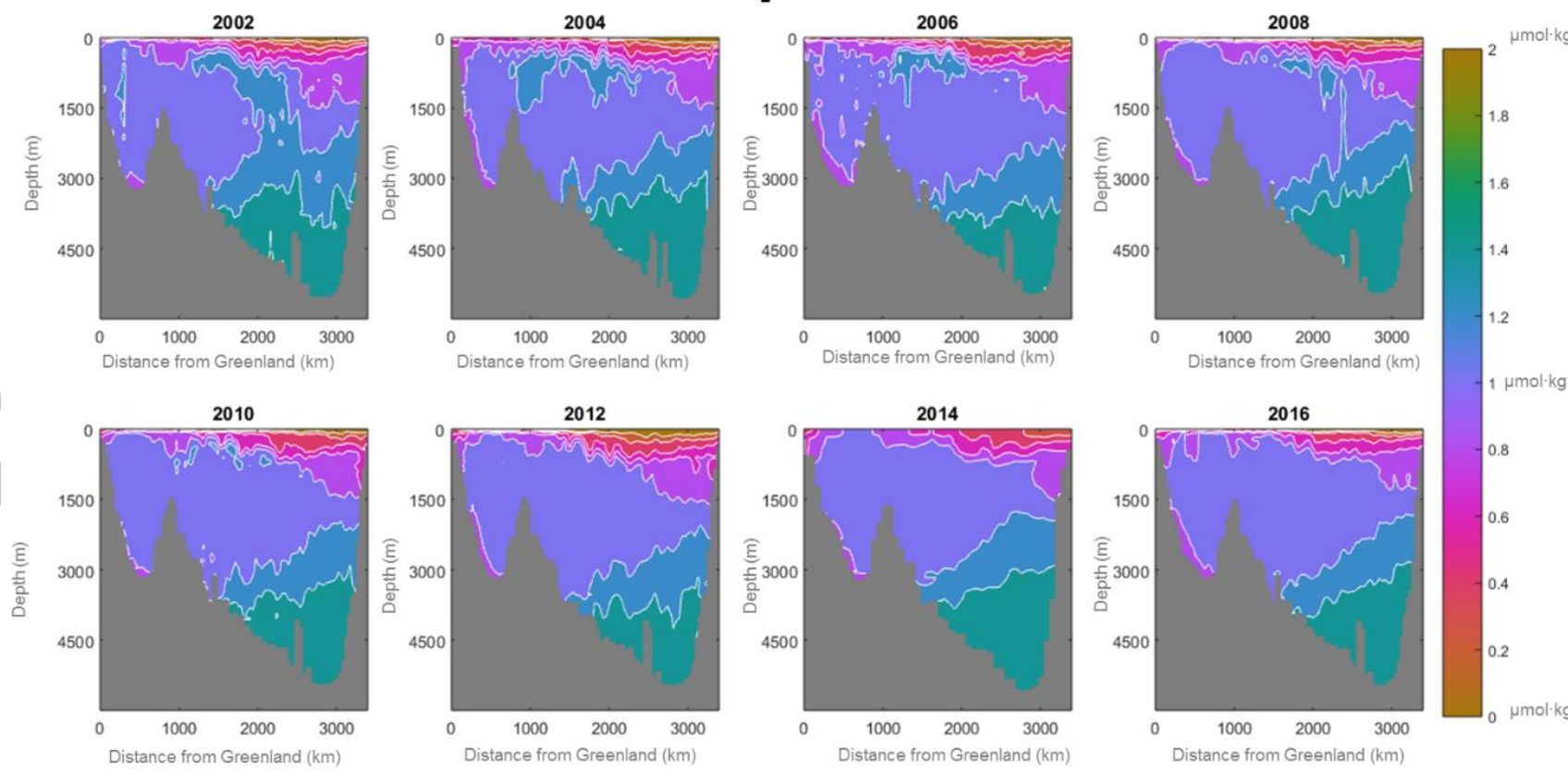

Figure 59. Phosphate $\left(\mathrm{PO}_{4}^{-}\right.$, in $\left.\mu \mathrm{mol} \cdot \mathrm{kg}^{-1}\right)$ vertical distribution along the OVIDE section from Greenland (left) to the Iberian Peninsula (right). Represented is the density interpolated bottle data from each one of the eight repetitions of the OVIDE section, from 2002 to 2016. 

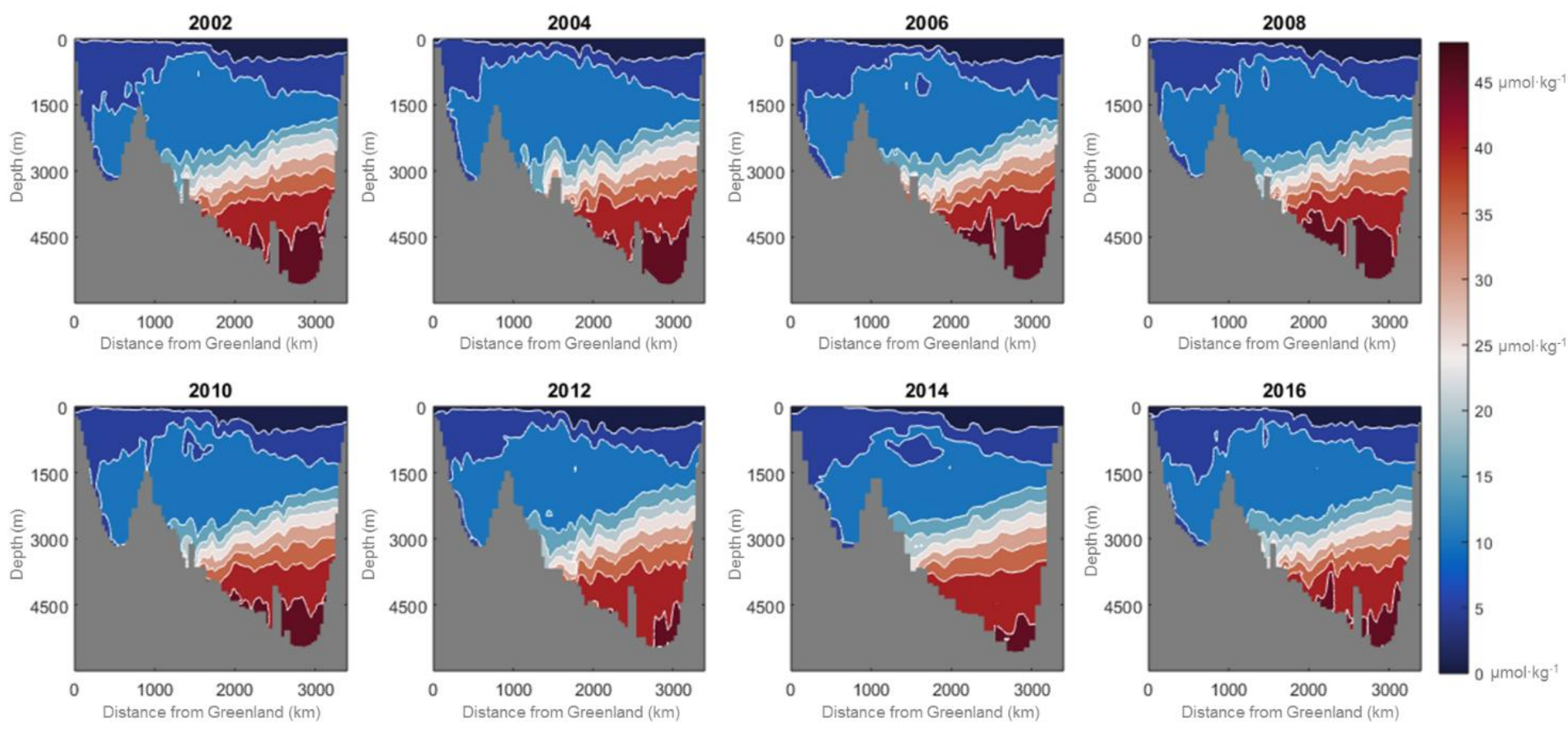

Figure S10. Silicate $\left(\mathrm{SiO}_{4}\right.$, in $\left.\mu \mathrm{mol} \cdot \mathrm{kg}^{-1}\right)$ vertical distribution along the OVIDE section from Greenland (left) to the lberian Peninsula (right). Represented is the density interpolated bottle data from each one of the eight repetitions of the OVIDE section, from 2002 to 2016.

\section{References}

Bakker, D.C.E., Pfeil, B., Landa, C.S., Metzl, N., O’Brien, K.M., Olsen, A., Smith, K., Cosca, C., Harasawa, S., Jones, S.D., Nakaoka, S.I., Nojiri, Y., Schuster, U., Steinhoff, T., Sweeney, C., Takahashi, T., Tilbrook, B., Wada, C., Wanninkhof, R., Alin, S.R., Balestrini, C.F., Barbero, L., Bates, N.R., Bianchi, A.A., Bonou, F., Boutin, J., Bozec, Y., Burger, E.F., Cai, W.J., Castle, R.D., Chen, L., Chierici, M., Currie, K., Evans, W., Featherstone, C., Feely, R.A., Fransson, A., Goyet, C., Greenwood, N., Gregor, L., Hankin, S., Hardman-Mountford, N.J., Harlay, J., Hauck, J., Hoppema, M., Humphreys, M.P., Hunt, C.W., Huss, B., Ib??nhez, J.S.P., Johannessen, T., Keeling, R., Kitidis, V., K??rtzinger, A., Kozyr, A., Krasakopoulou, E., Kuwata, A., Landsch??tzer, P., Lauvset, S.K., Lef??vre, N., Lo Monaco, C., Manke, A., Mathis, J.T., Merlivat, L., Millero, F.J., Monteiro, P.M.S., Munro, D.R., Murata, A., Newberger, T., Omar, A.M., Ono, T., Paterson, K., Pearce, D., Pierrot, D., Robbins, L.L., Saito, S., Salisbury, J., Schlitzer, R., Schneider, B., Schweitzer, R., Sieger, R., Skjelvan, I., Sullivan, K.F., Sutherland, S.C., Sutton, A.J., Tadokoro, K., Telszewski, M., Tuma, M., Van Heuven, S.M.A.C., Vandemark, D., Ward, B., Watson, A.J., Xu, S., 2016. A multi-decade record of high-quality fCO2 data in version 3 of the Surface Ocean $\mathrm{CO} 2$ Atlas (SOCAT). Earth Syst. Sci. Data 8, 383-413. doi:10.5194/essd-8-383-2016

Brzezinski, M.A., Nelson, D.M., 1996. Chronic substrate limitation of silicic acid uptake rates in the western Sargasso Sea. Deep Sea Res. Part II Top. Stud. Oceanogr. 43, 437-453. doi:10.1016/0967-0645(95)00099-2 
Codispoti, L.A., Brandes, J.A., Christensen, J.P., Devol, A.H., Naqvi, S.W.A., Paerl, H.W., Yoshinari, T., 2001. The oceanic fixed nitrogen and nitrous oxide budgets: Moving targets as we enter the anthropocene? Sci. Mar. doi:10.3989/scimar.2001.65s285

Fay, A.R., Mckinley, G.A., 2014. Global open-ocean biomes : mean and temporal variability 273-284. doi:10.1594/PANGAEA.828650

Galloway, J.N., Dentener, F.J., Capone, D.G., Boyer, E.W., Howarth, R.W., Seitzinger, S.P., Asner, G.P., Cleveland, C.C., Green, P.A., Holland, E.A., Karl, D.M., Michaels, A.F., Porter, J.H., Townsend, A.R., Vörösmarty, C.J., 2004. Nitrogen cycles: Past, present, and future. Biogeochemistry. doi:10.1007/s10533-004-0370-0

Ganachaud, A., Wunsch, C., 2002. Oceanic nutrient and oxygen transports and bounds on export production during the World Ocean Circulation Experiment. Global Biogeochem. Cycles 16, 5-1-5-14. doi:10.1029/2000GB001333

Gruber, N., 2008. The Marine Nitrogen Cycle: Overview and Challenges, in: Nitrogen in the Marine Environment. doi:10.1016/B978-0-12-372522-6.00001-3

Hawkings, J., Wadham, J., Tranter, M., Telling, J., Bagshaw, E., Beaton, A., Simmons, S.L., Chandler, D., Tedstone, A., Nienow, P., 2016. The Greenland Ice Sheet as a hot spot of phosphorus weathering and export in the Arctic. Global Biogeochem. Cycles 30, 191-210. doi:10.1002/2015GB005237

Hawkings, J.R., Wadham, J.L., Benning, L.G., Hendry, K.R., Tranter, M., Tedstone, A., Nienow, P., Raiswell, R., 2017. Ice sheets as a missing source of silica to the polar oceans. Nat. Commun. 8, 14198. doi:10.1038/ncomms 14198

lida, Y., Kojima, A., Takatani, Y., Nakano, T., Sugimoto, H., Midorikawa, T., Ishii, M., 2015. Trends in pCO2 and sea-air $\mathrm{CO} 2$ flux over the global open oceans for the last two decades. J. Oceanogr. 71, 637-661. doi:10.1007/s10872-015-0306-4

Jeansson, E., Olsen, A., Eldevik, T., Skjelvan, I., Omar, A.M., Lauvset, S.K., Nilsen, J.E.Ø., Bellerby, R.G.J., Johannessen, T., Falck, E., 2011. The Nordic Seas carbon budget: Sources, sinks, and uncertainties. Global Biogeochem. Cycles 25, 1-16. doi:10.1029/2010GB003961

Jickells, T.D., Buitenhuis, E., Altieri, K., Baker, A.R., Capone, D., Duce, R.A., Dentener, F., Fennel, K., Kanakidou, M., LaRoche, J., Lee, K., Liss, P., Middelburg, J.J., Moore, J.K., Okin, G., Oschlies, A., Sarin, M., Seitzinger, S., Sharples, J., Singh, A., Suntharalingam, P., Uematsu, M., Zamora, L.M., 2017. A reevaluation of the magnitude and impacts of anthropogenic atmospheric nitrogen inputs on the ocean. Global Biogeochem. Cycles 31, 289-305. doi:10.1002/2016GB005586

Jones, S.D., Le Quéré, C., Rödenbeck, C., Manning, A.C., Olsen, A., 2015. A statistical gapfilling method to interpolate global monthly surface ocean carbon dioxide data. J. Adv. Model. Earth Syst. 7, 1554-1575. doi:10.1002/2014MS000416

Landschützer, P., Gruber, N., Bakker, D.C.E., Schuster, U., Nakaoka, S., Payne, M.R., Sasse, T.P., Zeng, J., 2013. A neural network-based estimate of the seasonal to inter-annual variability of the Atlantic Ocean carbon sink. Biogeosciences 10, 7793-7815. doi:10.5194/bg-10-7793-2013 
Luo, Y.-W., Doney, S.C., Anderson, L.A., Benavides, M., Berman-Frank, I., Bode, A., Bonnet, S., Boström, K.H., Böttjer, D., Capone, D.G., Carpenter, E.J., Chen, Y.L., Church, M.J., Dore, J.E., Falcón, L.I., Fernández, A., Foster, R.A., Furuya, K., Gómez, F., Gundersen, K., Hynes, A.M., Karl, D.M., Kitajima, S., Langlois, R.J., LaRoche, J., Letelier, R.M., Marañón, E., McGillicuddy, D.J., Moisander, P.H., Moore, C.M., Mouriño-Carballido, B., Mulholland, M.R., Needoba, J.A., Orcutt, K.M., Poulton, A.J., Rahav, E., Raimbault, P., Rees, A.P., Riemann, L., Shiozaki, T., Subramaniam, A., Tyrrell, T., Turk-Kubo, K.A., Varela, M., Villareal, T.A., Webb, E.A., White, A.E., Wu, J., Zehr, J.P., 2012. Database of diazotrophs in global ocean: abundance, biomass and nitrogen fixation rates. Earth Syst. Sci. Data. doi:10.5194/essd-4-47-2012

Luo, Y.W., Lima, I.D., Karl, D.M., Deutsch, C.A., Doney, S.C., 2014. Data-based assessment of environmental controls on global marine nitrogen fixation. Biogeosciences. doi:10.5194/bg11-691-2014

Majkut, J.D., Sarmiento, J.L., Rodgers, K.B., 2014. A growing oceanic carbon uptake: Results from an inversion study of surface pCO2 data. Global Biogeochem. Cycles 28, 335-351. doi:10.1002/2013GB004585

Martin, J.H., Knauer, G.A., Karl, D.M., Broenkow, W.W., 1987. VERTEX: carbon cycling in the northeast Pacific. Deep Sea Res. Part A, Oceanogr. Res. Pap. 34, 267-285. doi:10.1016/0198-0149(87)90086-0

Mercier, H., Lherminier, P., Sarafanov, A., Gaillard, F., Daniault, N., Desbruyères, D., Falina, A., Ferron, B., Gourcuff, C., Huck, T., Thierry, V., 2015. Variability of the meridional overturning circulation at the Greenland-Portugal OVIDE section from 1993 to 2010. Prog. Oceanogr. 132, 250-261. doi:10.1016/j.pocean.2013.11.001

Moreira-Coello, V., Mouriño-Carballido, B., Marañón, E., Fernández-Carrera, A., Bode, A., Varela, M.M., 2017. Biological N2 Fixation in the Upwelling Region off NW Iberia: Magnitude, Relevance, and Players. Front. Mar. Sci. 4. doi:10.3389/fmars.2017.00303

Nakaoka, S., Telszewski, M., Nojiri, Y., Yasunaka, S., Miyazaki, C., Mukai, H., Usui, N., 2013. Estimating temporal and spatial variation of ocean surface pCO2 in the North Pacific using a self-organizing map neural network technique. Biogeosciences 10, 6093-6106. doi:10.5194/bg-10-6093-2013

Nelson, D.M., Brzezinski, M.A., 1997. Diatom growth and productivity in an oligotrophic midocean gyre: A 3-yr record from the Sargasso Sea near Bermuda. Limnol. Oceanogr. 42, 473-486. doi:10.4319/lo.1997.42.3.0473

Nelson, D.M., Tréguer, P., Brzezinski, M.A., Leynaert, A., Quéguiner, B., 1995. Production and dissolution of biogenic silica in the ocean: Revised global estimates, comparison with regional data and relationship to biogenic sedimentation. Global Biogeochem. Cycles 9, 359-372. doi:10.1029/95GB01070

Nondal, G., Bellerby, R.G.J., Olsen, A., Johannessen, T., Olafsson, J., 2009. Optimal evaluation of the surface ocean $\mathrm{CO}_{2}$ system in the northern North Atlantic using data from voluntary observing ships. Limnol. Oceanogr. Methods 7, 109-118. doi:10.4319/lom.2009.7.109

Park, G.H., Wanninkhof, R., Doney, S.C., Takahashi, T., Lee, K., Feely, R.A., Sabine, C.L., Trińlanes, J., Lima, I.D., 2010. Variability of global net sea-air CO2 fluxes over the last three decades using empirical relationships. Tellus, Ser. B Chem. Phys. Meteorol. 62, 
352-368. doi:10.1111/j.1600-0889.2010.00498.x

Peterson, B.J., Holmes, R.M., Mcclelland, J.W., Vo, C.J., Lammers, R.B., Shiklomanov, A.I., Shiklomanov, I.A., Rahmstorf, S., 2002. Increasing River Discharge to the Arctic Ocean. Science (80-. ). 298, 2171-2174.

Pondaven, P., Ruiz-Pino, D., Druon, J.N., Fravalo, C., Tréguer, P., 1999. Factors controlling silicon and nitrogen biogeochemical cycles in high nutrient, low chlorophyll systems (the Southern Ocean and the North Pacific): Comparison with a mesotrophic system (the North Atlantic). Deep. Res. Part I Oceanogr. Res. Pap. 46, 1923-1968. doi:10.1016/S09670637(99)00033-3

Ragueneau, O., Dittert, N., Pondaven, P., Tr, P., Corrin, L., 2002. Si / C decoupling in the world ocean : is the Southern Ocean different ? 49, 3127-3154.

Rivero-Calle, S., Del Castillo, C.E., Gnanadesikan, A., Dezfuli, A., Zaitchik, B., Johns, D.G., 2016. Interdecadal Trichodesmium variability in cold North Atlantic waters. Global Biogeochem. Cycles. doi:10.1002/2015GB005361

Robson, J., Ortega, P., Sutton, R., 2016. A reversal of climatic trends in the North Atlantic since 2005. Nat. Geosci. 9, 513-517. doi:10.1038/ngeo2727

Rödenbeck, C., Bakker, D.C.E., Gruber, N., lida, Y., Jacobson, A.R., Jones, S., Landsch??tzer, P., Metzl, N., Nakaoka, S., Olsen, A., Park, G.H., Peylin, P., Rodgers, K.B., Sasse, T.P., Schuster, U., Shutler, J.D., Valsala, V., Wanninkhof, R., Zeng, J., 2015. Data-based estimates of the ocean carbon sink variability - First results of the Surface Ocean pCO2 Mapping intercomparison (SOCOM). Biogeosciences 12, 7251-7278. doi:10.5194/bg-127251-2015

Rödenbeck, C., Bakker, D.C.E., Metzl, N., Olsen, A., Sabine, C., Cassar, N., Reum, F., Keeling, R.F., Heimann, M., 2014. Interannual sea-air CO\&lt;sub\&gt;2\&lt;/sub\&gt; flux variability from an observation-driven ocean mixed-layer scheme. Biogeosciences 11, 4599-4613. doi:10.5194/bg-11-4599-2014

Sasse, T.P., McNeil, B.I., Abramowitz, G., 2013. A new constraint on global air-sea CO2 fluxes using bottle carbon data. Geophys. Res. Lett. 40, 1594-1599. doi:10.1002/grl.50342

Schuster, U., McKinley, G.A., Bates, N., Chevallier, F., Doney, S.C., Fay, A.R., GonzálezDávila, M., Gruber, N., Jones, S., Krijnen, J., Landschützer, P., Lefèvre, N., Manizza, M., Mathis, J., Metzl, N., Olsen, A., Rios, A.F., Rödenbeck, C., Santana-Casiano, J.M., Takahashi, T., Wanninkhof, R., Watson, A.J., 2013. An assessment of the Atlantic and Arctic sea-air CO\&lt;sub\&gt;2\&lt;/sub\&gt; fluxes, 1990-2009. Biogeosciences 10, 607627. doi:10.5194/bg-10-607-2013

Sharples, J., Middelburg, J.J., Fennel, K., Jickells, T.D., 2016. What proportion of riverine nutrients reaches the open ocean? Global Biogeochem. Cycles. doi:10.1002/2016GB005483

Shutler, J.D., Land, P.E., Piolle, J.F., Woolf, D.K., Goddijn-Murphy, L., Paul, F., Girard-Ardhuin, F., Chapron, B., Donlon, C.J., 2016. FluxEngine: A flexible processing system for calculating atmosphere-ocean carbon dioxide gas fluxes and climatologies. J. Atmos. Ocean. Technol. 33, 741-756. doi:10.1175/JTECH-D-14-00204.1 
Steinfeldt, R., Rhein, M., Bullister, J.L., Tanhua, T., 2009. Inventory changes in anthropogenic carbon from 1997-2003 in the Atlantic Ocean between $20^{\circ} \mathrm{S}$ and $65^{\circ} \mathrm{N}$. Global Biogeochem. Cycles 23, 1-11. doi:10.1029/2008GB003311

Takahashi, T., Sutherland, S.C., Wanninkhof, R., Sweeney, C., Feely, R.A., Chipman, D.W., Hales, B., Friederich, G., Chavez, F., Sabine, C., Watson, A., Bakker, D.C.E., Schuster, U., Metzl, N., Yoshikawa-Inoue, H., Ishii, M., Midorikawa, T., Nojiri, Y., Körtzinger, A., Steinhoff, T., Hoppema, M., Olafsson, J., Arnarson, T.S., Tilbrook, B., Johannessen, T., Olsen, A., Bellerby, R., Wong, C.S., Delille, B., Bates, N.R., de Baar, H.J.W., 2009. Climatological mean and decadal change in surface ocean pCO2, and net sea-air $\mathrm{CO} 2 \mathrm{flux}$ over the global oceans. Deep. Res. Part II Top. Stud. Oceanogr. 56, 554-577. doi:10.1016/j.dsr2.2008.12.009

Valsala, V., Maksyutov, S., 2010. Simulation and assimilation of global ocean pCO2 and air-sea CO2 fluxes using ship observations of surface ocean pCO2 in a simplified biogeochemical offline model. Tellus, Ser. B Chem. Phys. Meteorol. 62, 821-840. doi:10.1111/j.16000889.2010.00495.x

Yang, S., Gruber, N., 2016. The anthropogenic perturbation of the marine nitrogen cycle by atmospheric deposition. Glob. Biogeochem. Cycles 1418-1440. doi:10.1002/2016GB005421.Received

Zehr, J.P., Kudela, R.M., 2011. Nitrogen Cycle of the Open Ocean: From Genes to Ecosystems. Ann. Rev. Mar. Sci. 3, 197-225. doi:10.1146/annurev-marine-120709-142819

Zeng, J., Nojiri, Y., Landschützer, P., Telszewski, M., Nakaoka, S., 2014. A global surface ocean fCO2 climatology based on a feed-forward neural network. J. Atmos. Ocean. Technol. 31, 1838-1849. doi:10.1175/JTECH-D-13-00137.1

Zunino, P., Lherminier, P., Mercier, H., Daniault, N., Isabel, M., 2017. The GEOVIDE cruise in May-June 2014 reveals an intense Meridional Overturning Circulation over a cold and fresh subpolar North Atlantic. 